INTER NATIONAL MONETARY FUND
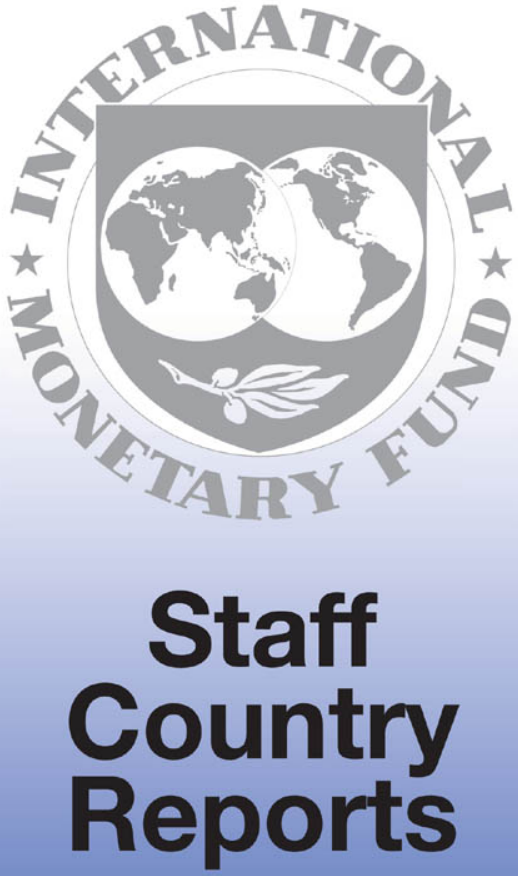


\section{United Kingdom: Stress Testing the Banking Sector Technical Note}

This paper was prepared based on the information available at the time it was completed on July 11, 2011. The views expressed in this document are those of the staff team and do not necessarily reflect the views of the government of the United Kingdom or the Executive Board of the IMF.

The policy of publication of staff reports and other documents by the IMF allows for the deletion of market-sensitive information.

Copies of this report are available to the public from

International Monetary Fund • Publication Services

700 19th Street, N.W. • Washington, D.C. 20431

Telephone: (202) 623-7430 • Telefax: (202) 623-7201

E-mail: publications@imf.org • Internet: http://www.imf.org

\section{International Monetary Fund \\ Washington, D.C.}


FinANCIAL SECTOR ASSESSMENT PROGRAM UpDATE UNITED KINGDOM

Stress Testing the BANKING SECtor

TECHNICAL NOTE

JULY 2011

\author{
INTERNATIONAL MONETARY FUND \\ MONETARY AND CAPITAL MARKETS DEPARTMENT
}

CInternational Monetary Fund. Not for Redistribution 
Glossary

Executive Summary

I. Introduction

II. Solvency Stress Tests..... $\underline{15}$

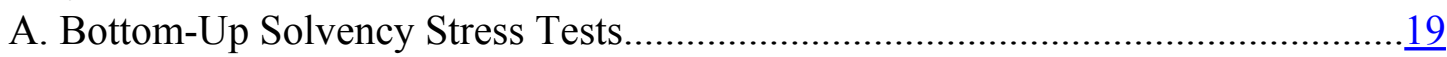

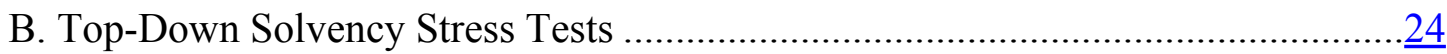

C. Reconciliation of Bottom-Up with Top-Down Solvency Stress Test Results .........43

III. Liquidity Stress Tests

IV. Summary and Policy Implications

References

Tables

1. Selected Advanced Economies: Recovery of Outlays and Net Cost of Financial Sector Support.....

2. Composition of the Banking System and Banks Included in the FSAP Update Stress Testing Exercise $\underline{14}$

3. Overview of the Basel II and III Minimum Capital Requirements $\underline{18}$

4. Individual Contributions of Large Banks to Systemic Risk During the CrisisMarket-Implied Joint Capital Losses

5. Systemic CCA Estimates of the Market-Implied Joint Potential Capital Loss and Resulting Shortfall from the U.K. FSAP Update Top-Down Stress Tests, 2011-15...41

6. Systemic CCA Estimates of the Market-Implied Total Potential Capital Loss from the U.K. FSAP Update Top-Down Stress Tests, 2011-15

7. U.K. FSAP Update Liquidity Stress Tests: 5- and 30-Day Implied Cash Flow Analysis

8. U.K. FSAP Update Liquidity Stress Tests: Quasi-Basel III and Maturity Mismatch Analysis.

Figures

1. $\quad$ Major U.K. Banks: Differentiated Business and Geographic Models.......................... 2

2. U.K. Banks: Breakdown of Assets and Risk-Weighted Assets ..................................10

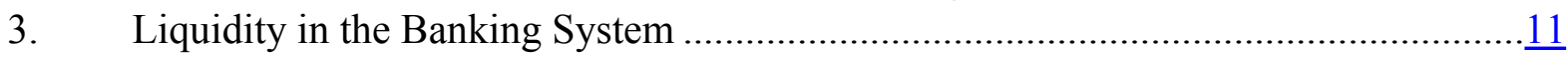

4. Overview of the U.K. FSAP Update Stress Testing Exercise …………....................13

5. Overview of the U.K. FSAP Update Stress Test Scenarios.......................................17

6. Distribution of Core Tier 1 Capital Ratios from the U.K. FSAP Update Bottom-Up Stress Tests, 2011-15. 
7. Distribution of Tier 1 Capital Ratios from the U.K. FSAP Update Bottom-Up Stress Tests, 2011-15.

8. Distribution of Total Capital Ratios from the U.K. FSAP Update Bottom-Up Stress Tests, 2011-15. .$\underline{23}$

9. Estimation of Satellite Models in the U.K. FSAP Update Stress Testing Exercise......28

10. Application of Satellite Output in the RAMSI and the Systemic CCA Stress Tests...29

11. Distribution of Core Tier 1 Capital Ratios from the BoE RAMSI Top-Down Stress Tests for the U.K. FSAP Update, 2011-15. .$\underline{30}$

12. Distribution of Tier 1 Capital Ratios from the BoE RAMSI Top-Down Stress Tests for the U.K. FSAP Update, 2011-15

13. Distribution of Total Capital Ratios from the BoE RAMSI Top-Down Stress Tests for the U.K. FSAP Update, 2011-15 .......................................................................

14. Systemic CCA Estimates of the Market-Implied Joint-Capital Losses from the U.K. FSAP Update Top-Down Stress Tests, Historical and Expected ………......................39

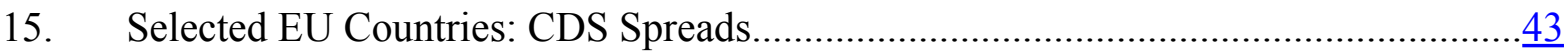

16. Weighted-Average Core Tier 1 Capital Ratios from the U.K. FSAP Update BottomUp and BoE RAMSI Top-Down Stress Tests, 2011-15

17. Tier 1 Capital Ratios from the U.K. FSAP Update Bottom-Up and BoE RAMSI TopDown Stress Tests, 2011-15 .............................................................................. 46

18. Total Capital Ratios from the U.K. FSAP Update Bottom-Up and BoE RAMSI TopDown Stress Tests, 2011-15.

Boxes

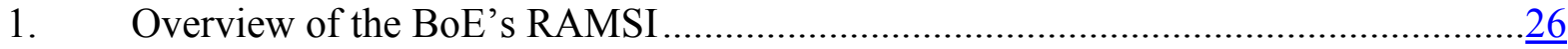

2: $\quad$ Overview of the Systemic CCA Framework ...........................................................

Appendices

I. Key Assumptions Applied in the U.K. FSAP Update Solvency Stress Tests Relative to the European Banking Authority and FSA Supervisory Stress Tests....................... $\underline{.65}$

II. Comparison of Capital Definitions - Basel, EBA, FSA and U.K. FSAP Update ......... $\underline{65}$

III. Parameters Applied in the U.K. FSAP Update Liquidity Stress Tests ........................

IV. The Contingent Claims Analysis (CCA) Approach: Standard Definition.....................

V. The Systemic CCA Methodology: Calculating the Systemic Worst-Case Scenario Using Multivariate Extreme Value Distribution

Attachments

Guidelines for the U.K. FSAP Update Bottom-Up Solvency Stress Tests by Banks $\underline{90}$ 


\section{GLOSSARY}

BoE

BU

BCBS

BSM

CCA

CDS

CRD

DD

EBA

EU

FSA

FSAP

FSCS

FSSA

GARCH

GEV

HMT

HSBC

ICAAP

ICB

LBG

LCR

LGD

LRS

MES

MGEV

NSFR

OPT

PD

RAM

RAMSI

RBS

RWAs

SCB

SG

SPD

TD

TN

VaR

WEO
Bank of England

Bottom-up

Basel Committee on Banking Supervision

Black-Scholes-Merton

Contingent Claims Analysis

Credit default swaps

Capital Requirements Directive

Double dip

European Banking Authority

European Union

Financial Services Authority

Financial Sector Assessment Program

Financial Services Compensation Scheme

Financial System Stability Assessment

Generalized auto-regressive conditional heteroskedasticity

Generalized extreme value

Her Majesty's Treasury

Hongkong and Shanghai Banking Corporation

Internal Capital Adequacy Assessment Process

Independent Commission on Banking

Lloyds Banking Group

Liquidity Coverage Ratio

Loss-given-default

Linear Ratio of Spacings

Marginal Expected Shortfall

Multivariate extreme value

Net Stable Funding Ratio

Option Pricing Theory

Probability of default

Risk Assessment Matrix

Risk Assessment Model for Systemic Institutions

Royal Bank of Scotland

Risk-weighted assets

Standard Chartered Bank

Slow growth

State price density

Top down

Technical Note

Value-at-Risk

World Economic Outlook 


\section{EXECUTIVE SUMMARY}

The U.K. Financial Sector Assessment Program (FSAP) Update stress testing exercise comprises a comprehensive analysis of solvency and liquidity risks of key institutions in the U.K. banking system, using end-2010 data. Solvency tests consist of bottom-up (BU) stress tests by the 7 biggest banks in the United Kingdom and cross-validation by top-down (TD) tests undertaken by the U.K. authorities and the FSAP team, all over a five-year horizon; liquidity stress tests consist of TD tests of 16 institutions by the U.K. authorities.

The stress tests are organized in collaboration with the authorities. The solvency tests are based on three adverse macroeconomic scenarios and their deviation from the IMF's World Economic Outlook (WEO) baseline. They comprise a mild double-dip recession; a severe double-dip recession; and a prolonged slow growth scenario. Hurdle rates are applied according to the Basel III implementation schedule and compared with the FSA's Interim Capital Regime requirements. Liquidity tests, using supervisory data and parameters specified by the FSAP team, focus on sudden, sizeable withdrawal of funding (liabilities) and the sufficiency of existing assets to withstand those shocks under stressed conditions. Implied cash flow tests (over five- and 30-day periods), as well as Basel III-type Liquidity Coverage Ratio (LCR) and Net Stable Funding Ratio (NSFR) tests are applied to determine the shortand medium-term resilience of individual banks and the overall system, without taking into account access to central bank liquidity.

The solvency tests show that banks have solid capital buffers and are resilient against severe stresses, but that the realization of an extreme "tail of the tail" risk confluence of multiple severe shocks to the banking system could pose challenges. The substantial recapitalization of the U.K. banking sector, including by the state, in tandem with the derisking of balance sheets, has been critical in boosting the solvency of the system. Both the BU results as well as the authorities' TD tests show banks' capital adequacy levels to be well above the Basel III minimum (and above the FSA's required post-stress levels) following the prescribed shocks; the FSAP's TD stress test results are also consistent in showing that markets consider the banking system to be sufficiently capitalized to withstand the prescribed central case shock scenarios. However, rapidly rising risks in vulnerable European Union (EU) countries pose risks to banks across the EU and may threaten the U.K. banks if they crystalize in an extreme tail risk scenario. While U.K. banks' direct exposures to vulnerable EU sovereigns are relatively low, they have direct exposures to the private sector in those countries and indirect exposures through core European banks.

\section{Banks have continued to improve their funding profiles, but need to significantly} reduce their reliance on short-term funding. There are sufficient liquid assets in the banking system to withstand short-lived stresses, and the shortfall appears largely contained even under very severe test conditions. However, the system, in aggregate, remains vulnerable to sustained disruptions to wholesale funding markets. Funding sources are not sufficiently stable, and banks have mismatched assets and liabilities at six-month maturities and longer, which they are working to address. The interconnectedness of the U.K. banks to the global financial system amplifies the risks, which have risen sharply in recent months. 


\section{INTRODUCTION ${ }^{1}$}

\section{The U.K. FSAP stress testing exercise takes place following a period of} unrivalled turbulence and consolidation in the history of the country's financial sector. U.K. banks vary significantly in terms of their business models, risk management systems and geographic footprint and were accordingly affected differently by the crisis (Figure 1). Some large, systemically important banks were among those that felt the full brunt of the financial turmoil, and the U.K. authorities had to take decisive policy actions to restore stability to the financial system. The financial system is in the process of recovering but fragilities exist. The extent of its complexity and interconnectedness suggests that that it remains widely exposed to stresses originating domestically and elsewhere in the world, while being a potential conduit of shocks both locally and to the global financial system.

\section{Although conditions in the financial sector have improved significantly,} vulnerabilities remain and new risks loom. ${ }^{2}$ U.K. banks are continuing to de-risk their balance sheets, but the diversity across individual banks means that they continue to be exposed to different risks (Figure 2). For instance, retail-focused institutions are likely to be more vulnerable if the recovery of the U.K. economy remains weak for a prolonged period of time, unemployment rises sharply and the real estate sector comes under further pressure or if debt affordability were to be negatively affected by a sustained tightening in monetary policy in light of continuing upside surprises on inflation. Meanwhile, institutions that are more reliant on wholesale funding are more at risk in and are susceptible to disruptions from internal and external pressures - notably, those arising from the direct and indirect impact from the realization of sovereign risks from vulnerable EU countries - which could impair access and/or drive up the cost of funding (Figure 3).

\section{The financial crisis brought about a sharp deterioration in the United} Kingdom's public finances and fiscal space to further support the financial system is limited. Specific measures taken by the authorities have included acting as a lender of last resort to some banks; introducing exceptional liquidity support through the Special Liquidity Scheme; providing additional funding support through the Credit Guarantee Scheme; and creating the Asset Protection Scheme to provide participating institutions with protection against future credit losses. Additionally, the government injected a cumulative $£ 70$ billion of

\footnotetext{
${ }^{1}$ Prepared by Andreas Jobst and Li Lian Ong, with research assistance from Suchitra Kumarapathy (all IMF/MCM). The FSAP team would like to express its deep gratitude to counterparts at the Financial Services Authority (FSA) and the Bank of England (BoE) for their cooperation and close collaboration in facilitating this comprehensive stress testing exercise; staff at Her Majesty's Treasury (HMT) for their constructive input throughout the process; and management and the stress testing teams at Barclays, HongKong and Shanghai Banking Corporation (HSBC), Nationwide, Lloyds Banking Group (LBG), Royal Bank of Scotland (RBS), Santander U.K. and Standard Chartered Bank (SCB) for their participation.

${ }^{2}$ The Risk Assessment Matrix in the Financial System Stability Assessment details the risks, their estimated probability of occurrence and impact.
} 
capital into several banks. As a result, the direct cost of fiscal support by the U.K. government to the financial sector relative to GDP is one of the largest in the EU to date (Table 1). With gross general government debt currently at around 79 percent of GDP and expected to peak at 87 percent of GDP in 2013, there is limited fiscal space to accommodate any further substantial shocks to the financial system.

\section{The U.K. authorities have been very supportive of the FSAP mission} undertaking comprehensive and stringent stress tests of the banking sector. Both solvency and liquidity stress tests were conducted (Figure 4). The stress test analysis is based on end-2010 audited financial data of the key institutions in the U.K. financial system, as well as the macroeconomic projections and financial market information available at that time. The 6 largest U.K. banks plus the biggest building society (hereafter "seven major U.K. banks"), accounting for 71 percent of total banking assets, are included in the solvency stress tests; 16 financial institutions, covering those 7 major banks, other building societies, 1 cooperative bank and foreign investment bank subsidiaries, totaling more than 80 percent the total assets in their respective categories, are captured in the liquidity stress tests (Table 2). The FSAP's close collaboration with the authorities and banks means that granular supervisory information as well as banks' own internal data and are also used in the tests, in addition to publicly available information.

\section{The objective of the FSAP stress testing exercise is to assess the capital adequacy} and the stability of funding of the U.K. banking sector by exploring system-wide vulnerabilities under adverse macroeconomic conditions. The solvency tests consist of BU stress tests run by the seven major banks and separate TD tests undertaken by the U.K. authorities and the FSAP team. The FSA aggregated the BU results received from individual banks, which were then reconciled by the FSAP team with those generated by the BoE's Risk Assessment Model for Systemic Institutions (RAMSI) and the FSAP team's Systemic Contingent Claims Analysis (CCA) model. The liquidity stress tests consist of TD tests of sixteen institutions which were conducted by the U.K. authorities, using supervisory data and applying parameters specified by the FSAP team. Basel III standards are applied in both solvency and liquidity tests; the results are also compared against the FSA's interim supervisory framework requirements.

\section{Key risks over both the short and medium term are incorporated into the design} of the stress tests. More specifically, the U.K. financial system's general vulnerabilities to shocks triggered by specific risk factors, as discussed above, upcoming regulatory reforms, as well as the behavioral changes of banks are examined. Where relevant, the recapitalization needs are estimated. It should be noted, however, that FSAP stress tests are for surveillance purposes, with a medium-term focus. The tests typically involve very severe stress scenarios to assess the overall resilience of the financial system, but may be less prescriptive than supervisory stress tests given resource and time considerations. The results provide a basis for policy discussions with the authorities, but do not require management action by banks. 
7. Admittedly, the implementation of stress tests is conceptually challenging. For the U.K. banks, the assessment of vulnerabilities is not straightforward given the diversity of business models and global activities of the largest banks. Some of the presented findings are derived from valuation models that are subject to varying degrees of estimation uncertainty and assumptions, and these need to be taken into account when drawing policy conclusions. The key limitations are acknowledged and reflected as caveats in the relevant sections.

\section{Overall, the solvency analysis shows that the largest U.K. banks have solid} capital buffers that have reduced solvency concerns to a very low-probability confluence of adverse macroeconomic developments. Comprehensive BU stress tests by banks reveal adequate levels of capitalization even under severe macroeconomic stresses, with all banks passing the relevant Basel III and FSA hurdle rates under all adverse scenarios. The BoE RAMSI results show similar broad trends in terms of the overall solvency of the banking system in each scenario. Correspondingly, the forward-looking Systemic CCA model - which reflects market perceptions of each bank's risk profile and its contribution to the likelihood of joint distress - confirms that markets remain broadly comfortable with the capital adequacy of the seven major banks against the prescribed shocks, relative to both the Basel III and FSA capital requirements, and that only extreme tail-risk events could potentially give rise to capital shortfall in the system.

\section{At the same time, liquidity risks could potentially compromise the restoration of}

financial sector soundness. Although banks have made progress in moving away from less stable wholesale funding and towards deposit and secured term financing, the phasing-out of public sector support schemes and sizeable debt rollover over the next year leave many banks vulnerable to disruptions in funding markets. TD tests comprising reverse stress tests and proxies for the proposed liquidity measures under Basel III indicate that the banking system would be able to withstand moderately severe cash flow shocks.

\section{Nonetheless, any realization of very low probability extreme tail risk events} could still pose significant challenges. A situation where multiple banks concurrently experience a dramatic escalation of losses in a severe double-dip recession could result in a capital shortfall within the banking system, of up to 1.8 percent of GDP. Bottom-up stress tests show credit shocks to be the key risk driver for banks, while sustained disruptions to wholesale funding markets (funding liquidity risk), coupled with a persistent decline in asset values (market liquidity risk), could expose vulnerabilities at six-month maturities and longer. Given the rising risks in vulnerable EU countries since the cut-off date for the FSAP stress tests, U.K. banks' exposures to the private sector in those countries and to core European banks could potentially lead to liquidity and solvency concerns (see discussion below). Further, market uncertainty over the ongoing deliberations by the Independent Commission on Banking (ICB), which could result in the ring-fencing of banking groups' operations, may unsettle funding markets for banks. 
11. This Technical Note is structured as follows. Section II presents the different components of the FSAP's solvency stress tests, analyzes the results of the BU tests and cross-validates with the findings of the TD tests. The findings of the liquidity stress testing exercise are covered in Section III, followed by the conclusion and discussion on policy implications of the findings, in Section IV.

Figure 1. Major U.K. Banks: Differentiated Business and Geographic Models

(In percent of individual banks' revenues)

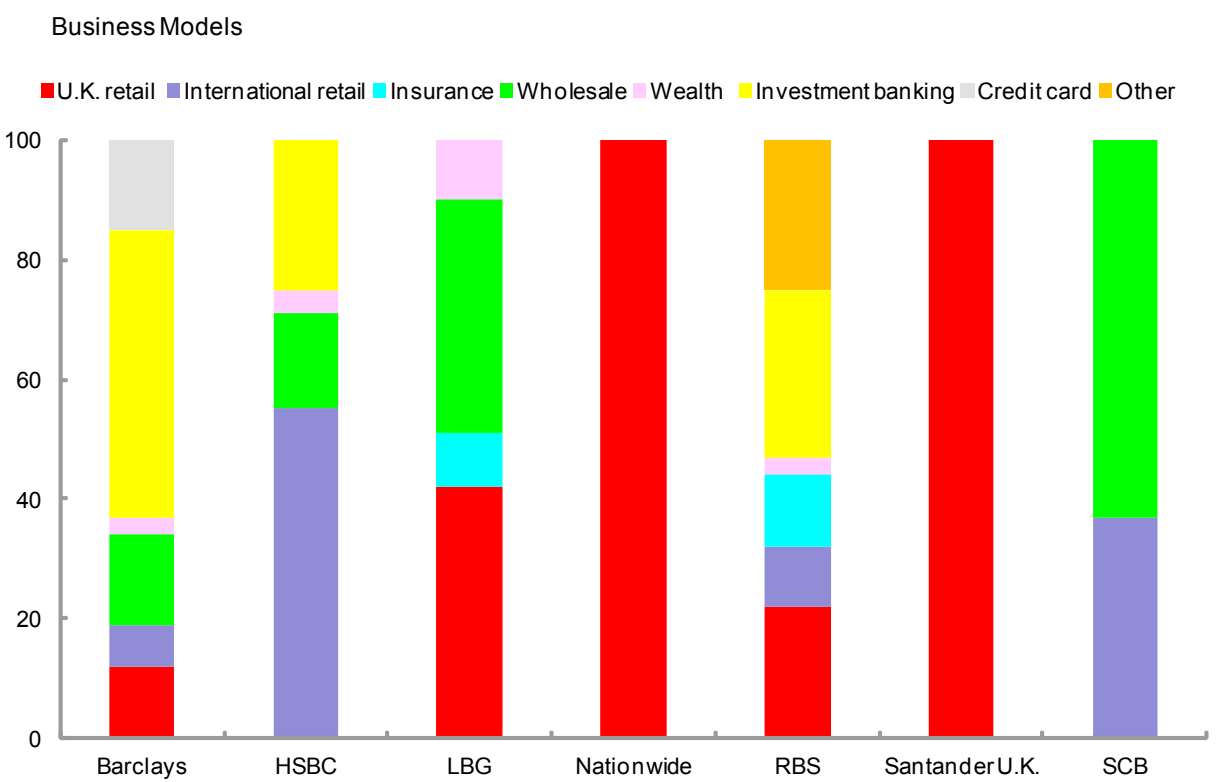

Geographic Footprints

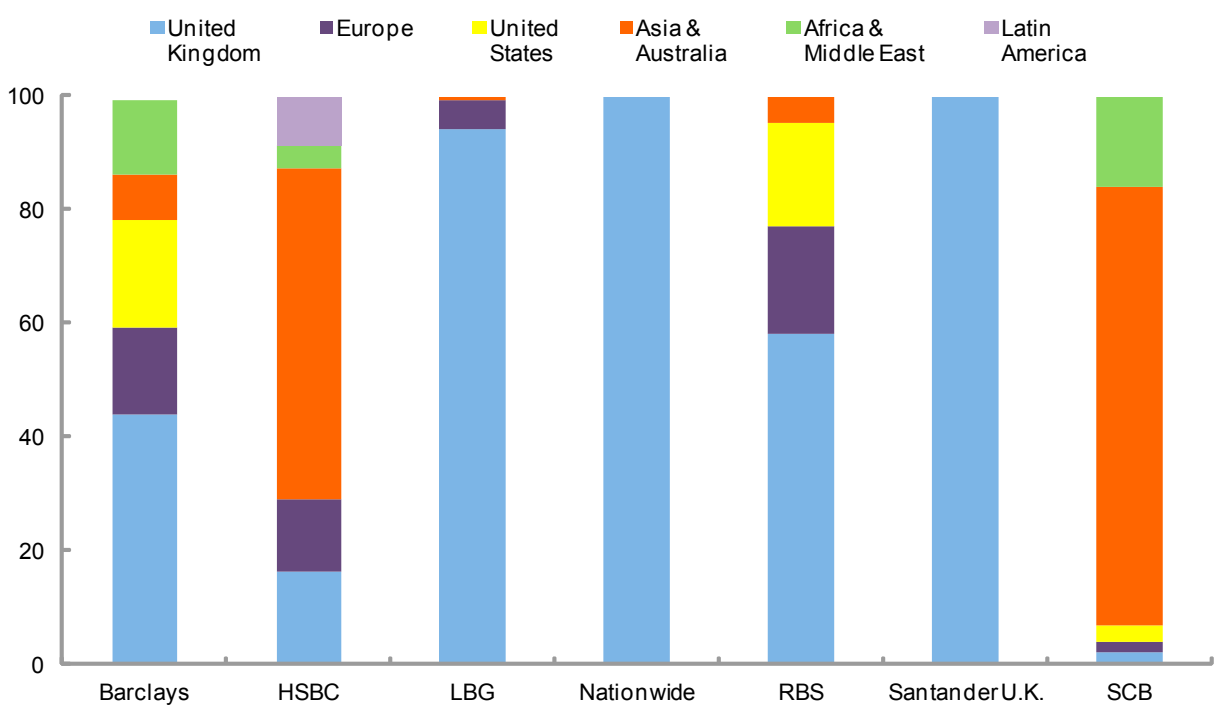

Sources: Bloomberg; individual bank reports; and IMF staff calculations. 
Figure 2. U.K. Banks: Breakdown of Assets and Risk-Weighted Assets

(In trillions of pound sterling)

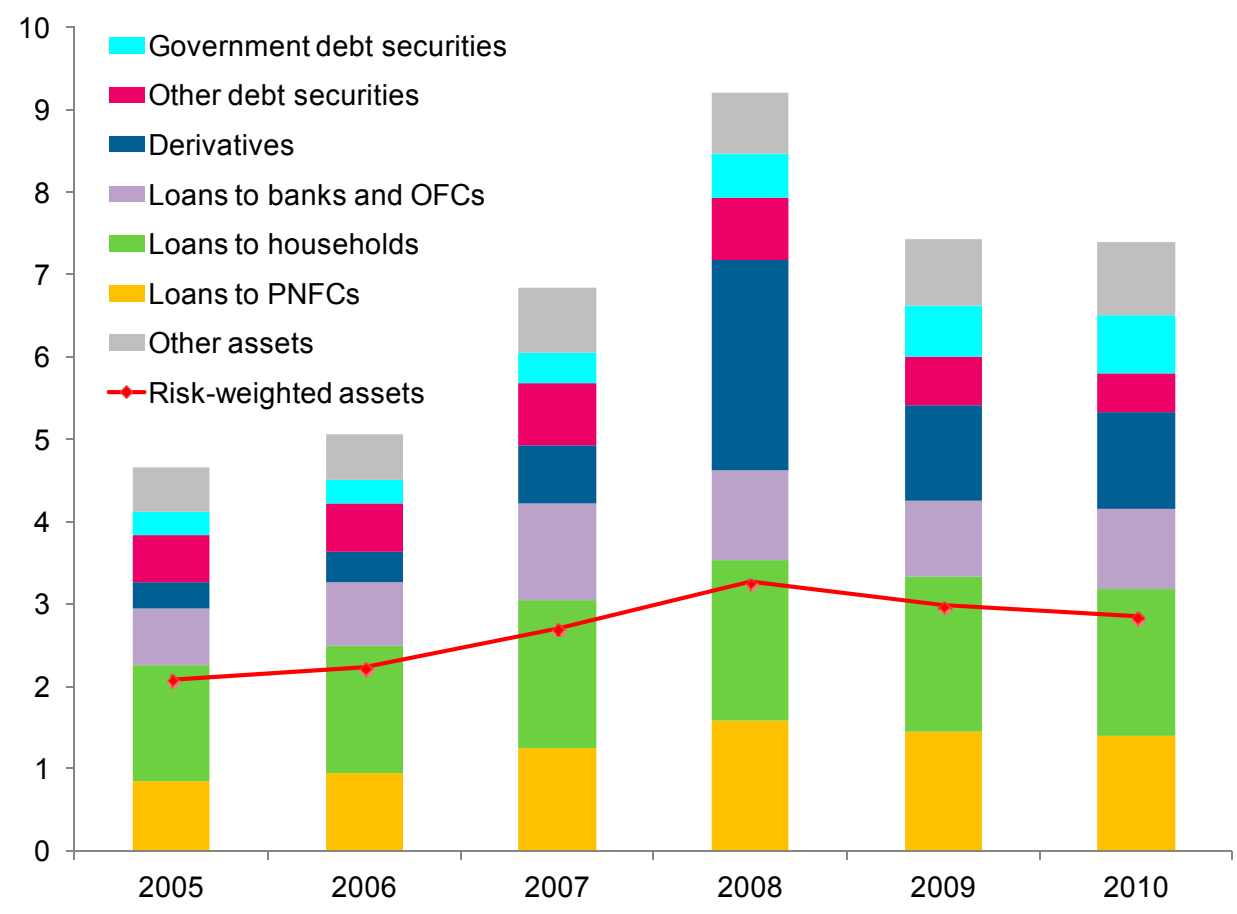

Source: BoE. 
Figure 3. United Kingdom: Liquidity in the Banking System
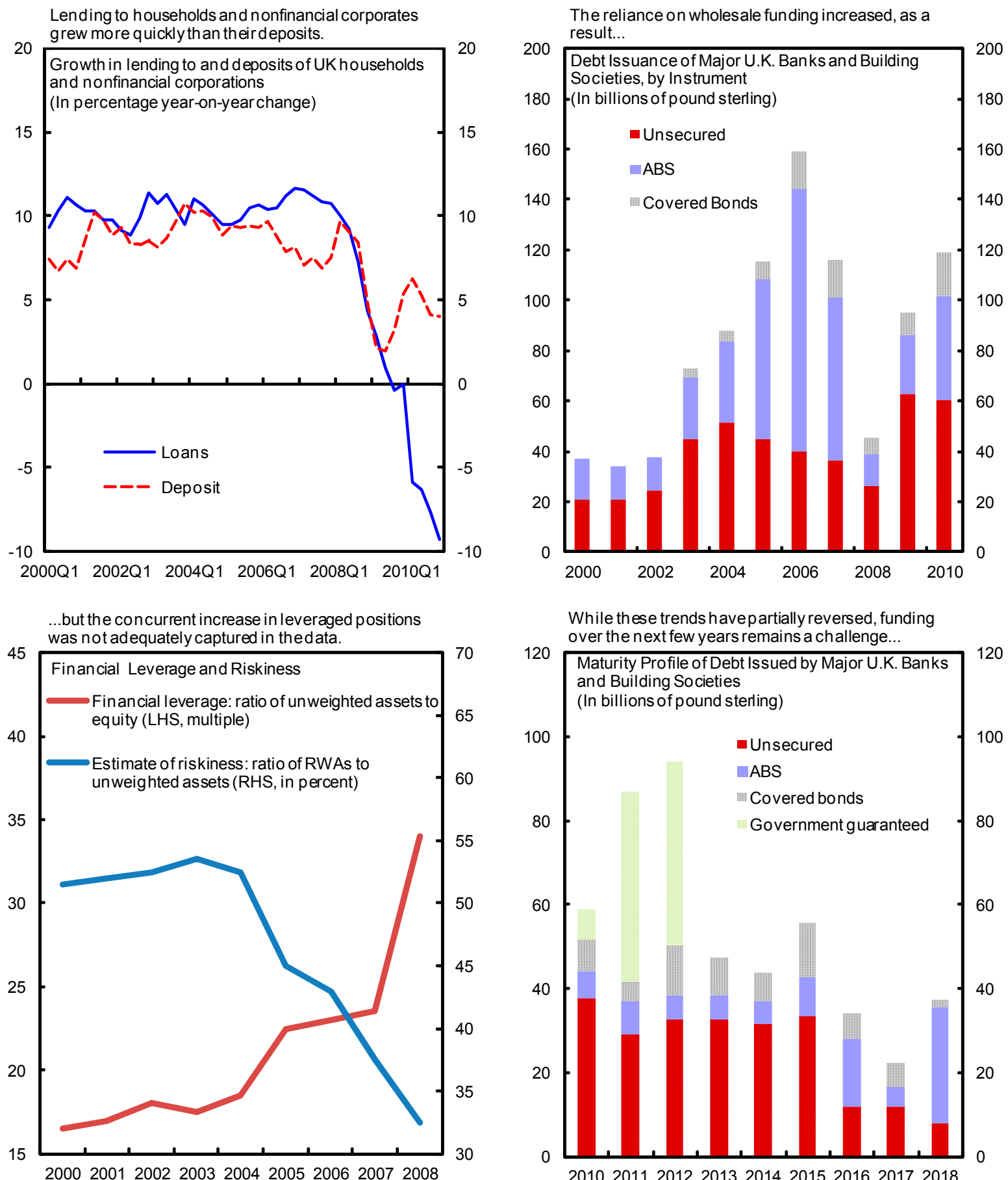

While these trends have partially reversed, funding over the next few years remains a challenge...

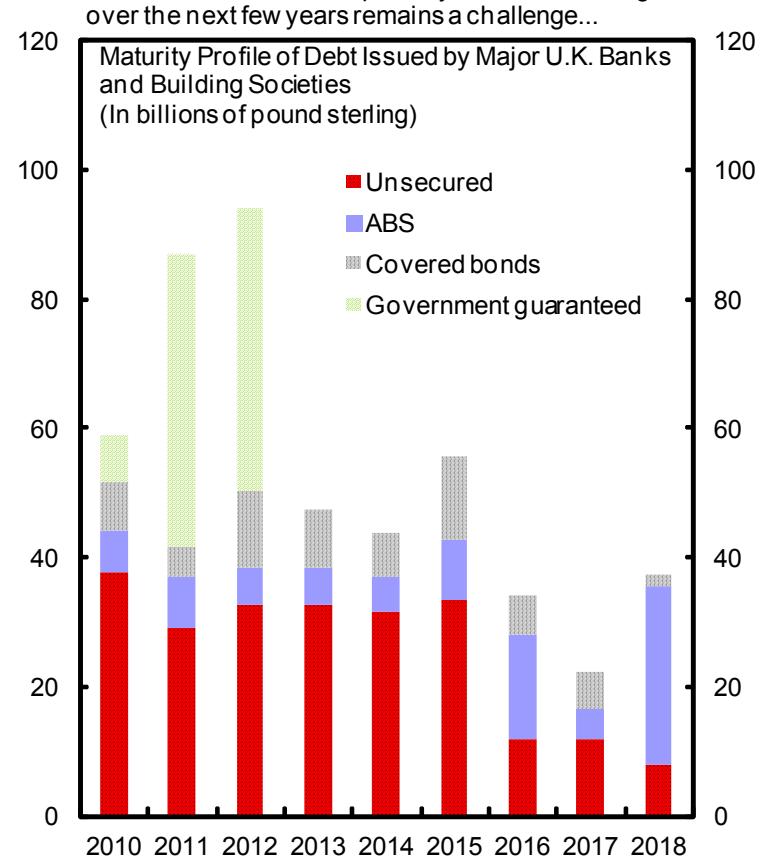

Sources: BoE; FSA calculations; CB Richard Ellis; De Montfort University; Dealogic DCM Analysis; financial statements of major U.K. banks; ICB; Office of National Statistics; and IMF staff calculations. 


\section{Table 1. Selected Advanced Economies: Recovery of Outlays and Net Cost of Financial Sector Support 1/}

(Latest available date; in percent of 2010 GDP unless otherwise indicated)

\begin{tabular}{lrcr}
\hline & Direct Support & Recovery & Net Direct Cost \\
\hline Belgium & & & \\
Ireland 2/ & 4.3 & 0.2 & 4.1 \\
Germany 3/ & 30.0 & 1.3 & 28.7 \\
Greece & 10.8 & 0.1 & 10.7 \\
Netherlands & 5.1 & 0.1 & 5.0 \\
Spain & 14.4 & 8.4 & 6.0 \\
United Kingdom & 2.9 & 0.9 & 2.0 \\
United States & 7.1 & 1.1 & 6.0 \\
& 5.2 & 1.8 & 3.4 \\
\hline
\end{tabular}

Source: Fiscal Monitor, IMF.

Note: Fiscal outlays of the central government. In addition, some countries may have supported financial institutions via fiscal outlays at the subnational level or through other public sector institutions. For example, in Germany, capital injections from the Laender and KfW (development bank) amount to 1.1 percent of GDP; in Belgium, financial sector support from regional government amount to 1.6 percent of GDP.

$1 /$ Cumulative since the beginning of the crisis; latest available data, ranging between endDecember 2010 and end-March 2011.

2/ Direct support does not include asset purchases by the National Asset Management Agency, as these are not financed directly through the general government but with government-guaranteed bonds.

3/ Direct support includes an estimated amount of $€ 240$ billion ( $91 / 2$ percent of GDP) for asset purchases. 


\section{U.K. FSAP Update stress tests}

\section{Type \\ Specification}

Coverage

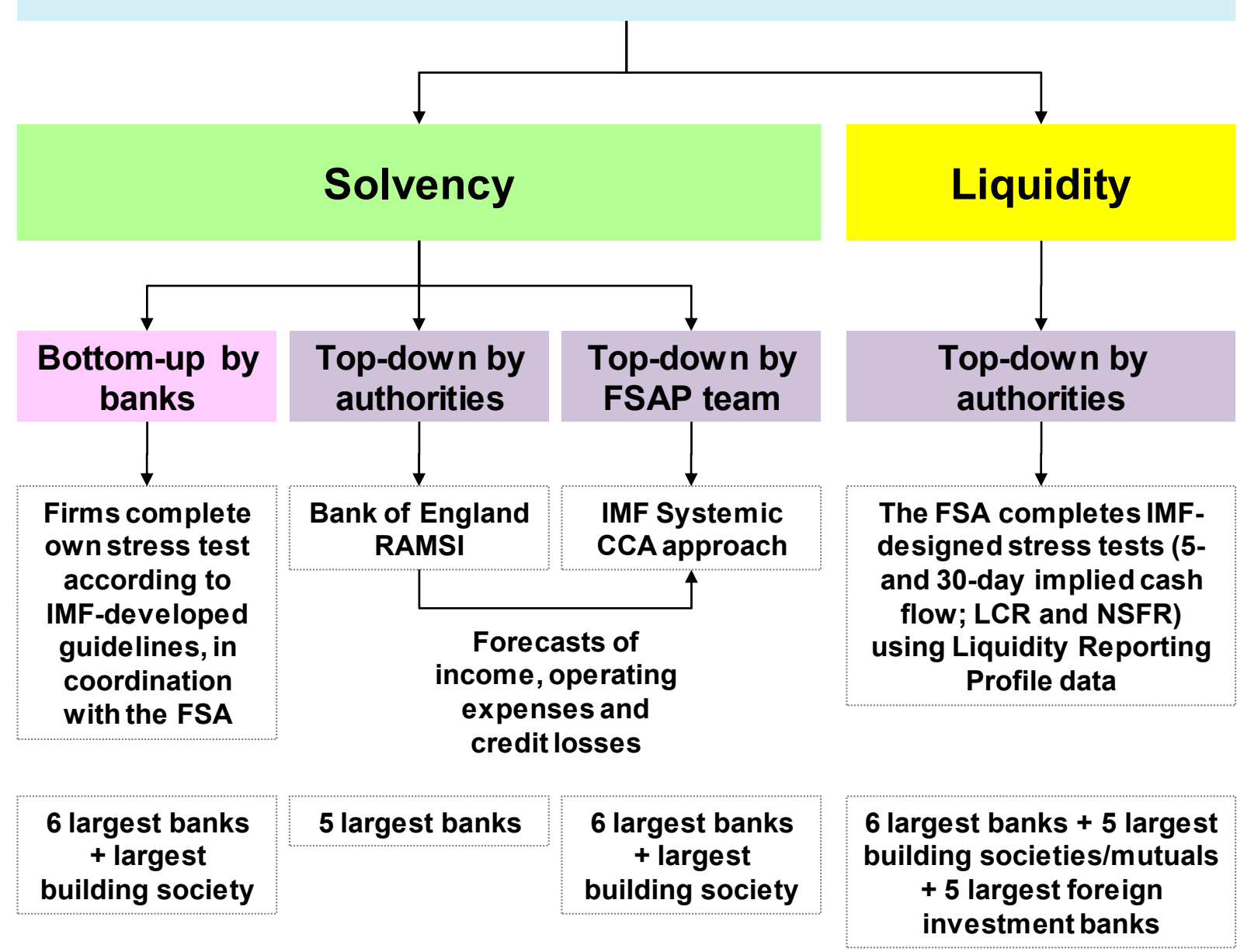


Table 2. United Kingdom: Composition of the Banking System and Banks Included in the FSAP Update Stress Testing Exercise

\begin{tabular}{|c|c|c|c|c|c|c|c|c|}
\hline \multirow[t]{2}{*}{ Firm } & \multicolumn{2}{|c|}{ Assets } & \multicolumn{2}{|c|}{ Loans and advances to customers $1 /$} & \multicolumn{3}{|c|}{ Solvency Stress Test } & \multirow{2}{*}{$\begin{array}{l}\text { Liquidity Stress Test } \\
\text { Top-down: } \\
\text { FSA-IMF }\end{array}$} \\
\hline & $\begin{array}{c}\text { Amount } \\
\text { (Millions of GBP) }\end{array}$ & $\begin{array}{c}\text { Firm/Banking Sector } \\
\text { (Percent of total) }\end{array}$ & $\begin{array}{c}\text { Amount } \\
\text { (Millions of GBP) }\end{array}$ & $\begin{array}{c}\text { Firm/Banking Sector } \\
\text { (Percent of total) }\end{array}$ & $\begin{array}{l}\text { Bottom-up: } \\
\text { FSA-IMF }\end{array}$ & $\begin{array}{l}\text { Top-down: } \\
\text { BoE RAMSI }\end{array}$ & $\begin{array}{c}\text { Top-down: } \\
\text { IMF Systemic CCA }\end{array}$ & \\
\hline Major U.K.-owned banks & $6,060,342$ & 66.4 & $2,303,115$ & 78.0 & & & & \\
\hline $\mathrm{HSBC}^{*}$ & & & & & 0 & 0 & 0 & 0 \\
\hline Barclays* & & & & & 0 & 0 & 0 & 0 \\
\hline $\mathrm{RBS}^{*}$ & & & & & 0 & $\mathrm{o}$ & 0 & $\mathrm{o}$ \\
\hline LBG $^{*}$ & & & & & 0 & 0 & 0 & 0 \\
\hline Standard Chartered ${ }^{*}$ & & & & & 0 & $\mathrm{x}$ & 0 & 0 \\
\hline Other & & & & & $\mathrm{x}$ & $\mathrm{x}$ & $\mathrm{x}$ & $\mathrm{x}$ \\
\hline Building societies and mutuals & 368,443 & 4.0 & 280,144 & 9.5 & & & & \\
\hline Nationwide* & & & & & 0 & $\mathrm{x}$ & 0 & 0 \\
\hline Yorkshire & & & & & $\mathrm{x}$ & $\mathrm{x}$ & $\mathrm{x}$ & 0 \\
\hline Coventry & & & & & $\mathrm{x}$ & $\mathrm{x}$ & $x$ & 0 \\
\hline Co-op & & & & & $\mathrm{x}$ & $x$ & $\mathrm{x}$ & 0 \\
\hline Skipton & & & & & $x$ & $\mathrm{x}$ & $\mathrm{x}$ & 0 \\
\hline Other & & & & & $\mathrm{x}$ & $\mathrm{x}$ & $\mathrm{x}$ & $\mathrm{x}$ \\
\hline Foreign-owned retail banks & 495,220 & 5.4 & 302,694 & 10.2 & & & & \\
\hline Santander ${ }^{*}$ & & & & & 0 & 0 & 0 & 0 \\
\hline NAGE & & & & & $x$ & $\mathrm{x}$ & $\mathrm{x}$ & $\mathrm{x}$ \\
\hline Allied Irish & & & & & $\mathrm{x}$ & $\mathrm{x}$ & $\mathrm{x}$ & $\mathrm{x}$ \\
\hline Standard Bank & & & & & $\mathrm{x}$ & $\mathrm{x}$ & $\mathrm{x}$ & $\mathrm{x}$ \\
\hline FCE Group & & & & & $x$ & $x$ & $x$ & $x$ \\
\hline Other & & & & & $\mathrm{x}$ & $x$ & $x$ & $x$ \\
\hline Foreign investment banks & $2,208,055$ & 24.2 & 67,462 & 2.3 & & & & \\
\hline Credit Suisse & & & & & $\mathrm{x}$ & $\mathrm{x}$ & $\mathrm{x}$ & 0 \\
\hline Goldman Sachs & & & & & $x$ & $x$ & $\mathrm{x}$ & 0 \\
\hline Morgan Stanley & & & & & $x$ & $x$ & $x$ & 0 \\
\hline Nomura & & & & & $\mathrm{x}$ & $x$ & $x$ & 0 \\
\hline JP Morgan & & & & & $x$ & $\mathrm{x}$ & $x$ & 0 \\
\hline Other & & & & & $\mathrm{x}$ & $x$ & $x$ & $x$ \\
\hline Total & $9,132,060$ & 100.0 & $2,953,416$ & 100.0 & & & & \\
\hline
\end{tabular}

Sources: FSA; and BoE

Note: The core stress test sample, whose constituent members are marked "*," represents 71.1 percent of banking sector assets and 89 percent of loans and

advances to customers. "O" denotes financial institutions included in the stress test sample; "X" denotes those which are excluded. The BoE's RAMSI uses Santander Group data.

1/ Non-trading book. 


\section{SOLVENCY STRESS TESTS}

\section{Solvency stress tests based on banks' end-2010 audited financial results are} undertaken in this FSAP exercise. The objective is to determine the capacity of the banking sector to absorb any realization of key macro-financial risks, which would result in downside deviations from a defined baseline scenario. It should be emphasized that the stress tests are necessarily based on economic and market conditions as at the end of 2010, given the cut-off date of the exercise, and do not take into account recent developments in the international sphere.

\section{The three-pronged approach to stress testing consists of:}

- $\quad$ BU stress tests conducted by individual banks based on guidelines provided by the FSAP team, drawn up in collaboration with the U.K. authorities (Attachment). The institutions involved in this exercise are the six largest U.K. banks, Barclays, HSBC, LBG, RBS, Santander U.K. and SCB, plus the largest building society, Nationwide.

- Cross-validation of BU results through TD stress tests using the BoE's RAMSI. The banks included in this sample are Barclays, HSBC, LBG, RBS, Santander Group.

- $\quad$ Cross-validation of BU results by the FSAP team through TD stress tests using structural approach, the Systemic CCA framework. The banks included in this sample are Barclays, HSBC, LBG, RBS, Santander U.K., SCB and Nationwide.

14. Three types of growth trends and four macro scenarios, including three adverse ones based on different magnitudes of deviation of GDP from a baseline, are examined (Figure 5):

- The baseline, which is specified as the IMF's WEO baseline projections.

- Two "double-dip recession" scenarios comprising:

(i) One standard deviation shock to real GDP growth from the baseline growth trend over the first two years of a five-year horizon with positive adjustment dynamics during the subsequent three years in which a shock to economic growth results in a sharp decline in output and rising employment over two years ("mild double-dip recession" or "DD mild"). ${ }^{3}$

(ii) Two standard deviations of the same, consistent with the FSA's 2011 anchor scenario ("severe double-dip recession" or "DD severe").

\footnotetext{
${ }^{3}$ Based on the volatility of the two-year growth rate over 30 years as calculated by the FSA.
} 
- A prolonged slow growth-i.e., severe and long-term - scenario with a cumulative negative deviation of about 7.5 percentage points from baseline growth, or an average annual growth rate of about 0.9 percent over a five-year horizon, as a result of a permanent shock to productive capacity amid rising inflation expectations ("prolonged slow growth" or "SG").

\section{Macro projections and guidelines on selected parameters are consistently applied across the different approaches as much as possible:}

- $\quad$ Based on the growth scenarios, related key macro and financial variables are projected, using the FSA's macro models, for input into the solvency stress tests, namely, inflation, unemployment, residential and commercial real estate prices, short and long-term interest rates and equity prices (Figure 5).

- $\quad$ Prescriptive assumptions covering areas such as (i) risk factors (loss rates, profitability, fixed income holdings, exchange rates, taxes, debt haircuts, funding costs) account for credit, market and operational risks, while trading book stresses take into account exposures from any breakdown in hedged positions; (ii), behavioral adjustments (balance sheet growth, dividend payout, credit growth, asset disposal, capital raising); and (iii) regulatory changes (capital requirements, risk-weighted assets, definition of capital) are also provided for all three approaches (Appendix I).

- However, some elements have been excluded, such as on-going de-risking of balance sheets through restructuring - which is reflected in a gradual decrease of riskweighted assets (RWAs) - and potential risks from restructured loans that no longer meet contractual covenants. Potential mitigating factors such as contingent capital arrangements and bail-in provisions are also not considered.

16. Solvency is assessed in accordance with recent changes in regulations published by the Basel Committee on Banking Supervision (BCBS) in September and December 2010 ("Basel III") and compared against the FSA's requirements under its Interim Capital Regime. Thus, the hurdle rates applied in the FSAP stress tests follow the graduated schedule of Basel III (Table 3); since the conservation buffer will come into effect only after the end of the stress test horizon, it is not directly relevant for this exercise. The post-stress capital requirements under the FSA's Interim Capital Regime of 4 percent for common equity Tier 1 capital ratio and 6-7 percent for Tier 1 capital are juxtaposed against the results to determine banks' ability to meet the supervisor's requirements. 
Figure 5. Overview of the U.K. FSAP Update Stress Test Scenarios
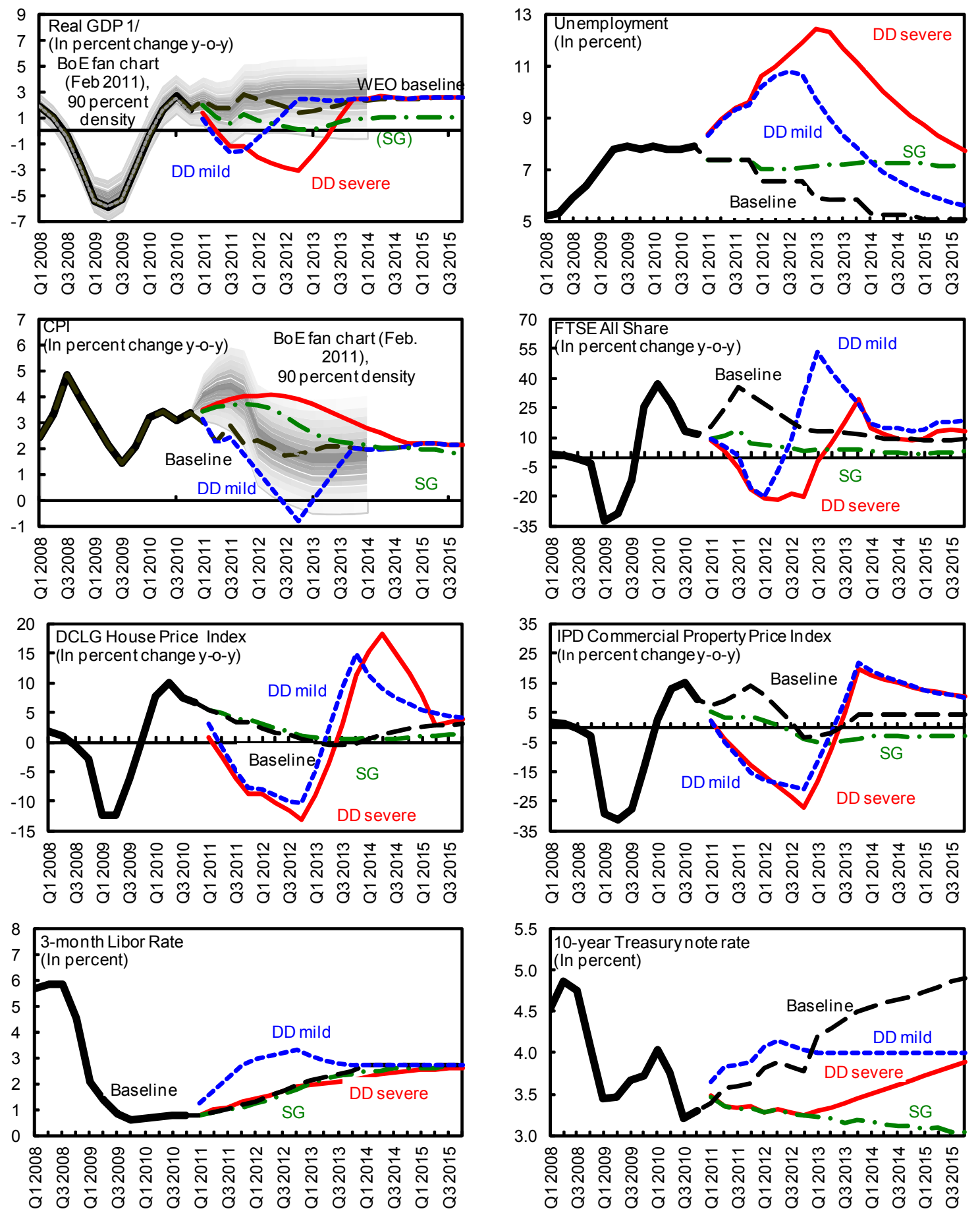

\footnotetext{
-- IMF mild double dip recession (DD mild) = European Banking Authority (EBA) 2011 adverse scenario.

- IMF severe double dip recession (DD severe) = FSA 2011 anchor scenario.

--- IMF Slow growth scenario (SG).
}

Sources: BoE; FSA; and IMF staff calculations. 
Table 3. Overview of the Basel II and III Minimum Capital Requirements

\begin{tabular}{|c|c|c|c|c|c|c|c|c|c|}
\hline \multicolumn{10}{|c|}{$\begin{array}{l}\text { Basel II and III: Current and Phase-In Arrangements } \\
\text { (All dates are as at January 1) }\end{array}$} \\
\hline & 2011 & 2012 & 2013 & 2014 & 2015 & 2016 & 2017 & 2018 & $\begin{array}{l}\text { As of } 1 \\
\text { January } \\
2019\end{array}$ \\
\hline Leverage ratio & \multicolumn{2}{|c|}{ Supervisory monitoring } & \multicolumn{4}{|c|}{$\begin{array}{c}\text { Parallel run } \\
\text { 1 Jan } 2013 \text { - } 1 \text { Jan } 2017 \\
\text { Disclosure starts } 1 \text { Jan } 2015\end{array}$} & & $\begin{array}{l}\text { Migration } \\
\text { to } \\
\text { Pillar } 1\end{array}$ & \\
\hline $\begin{array}{l}\text { Minimum Common Equity plus capital } \\
\text { conservation buffer }\end{array}$ & & & $3.5 \%$ & $4.0 \%$ & $4.5 \%$ & $5.125 \%$ & $5.750 \%$ & $6.375 \%$ & $7.0 \%$ \\
\hline $\begin{array}{l}\text { Phase-in of Deductions from CET1(including } \\
\text { amounts exceeding the limit for DIAs, MSRs and } \\
\text { financials) }\end{array}$ & & & & $20.0 \%$ & $40.0 \%$ & $60.0 \%$ & $80.0 \%$ & $100.0 \%$ & $100.0 \%$ \\
\hline Minimum Tier 1 Capital & $4.0 \%$ & $4.0 \%$ & $4.5 \%$ & $5.5 \%$ & $6.0 \%$ & $6.0 \%$ & $6.0 \%$ & $6.0 \%$ & $6.0 \%$ \\
\hline Liquidity coverage ratio & $\begin{array}{c}\text { Observation } \\
\text { period } \\
\text { begins }\end{array}$ & & & & $\begin{array}{l}\text { Introduce } \\
\text { minimum } \\
\text { standard }\end{array}$ & & & & \\
\hline Net stable funding ratio & & $\begin{array}{l}\text { Observation } \\
\text { period } \\
\text { begins }\end{array}$ & & & & & & $\begin{array}{l}\text { Introduce } \\
\text { minimum } \\
\text { standard }\end{array}$ & \\
\hline
\end{tabular}

Source: Basel Committee for Banking Supervision.

Currently Basel II.

Transition to Basel III.

CInternational Monetary Fund. Not for Redistribution 


\section{A. Bottom-Up Solvency Stress Tests}

17. The BU stress tests involving the seven major banks form the core element of the analytical framework for solvency risk. The exercise was administered jointly with the FSA, with banks conducting the stress tests using their own internal models. Detailed guidelines on assumptions were drawn up by the FSAP team in collaboration with the FSA and in consultation with the banks themselves and applied (Attachment). These guidelines contain key assumptions relating to the calibration and estimation of important risk drivers, which are necessary to ensure a robust and credible exercise. All banks in the sample have undergone, are or will be undergoing the FSA's supervisory stress tests under the Internal Capital Adequacy Assessment Process (ICAAP), which provides further opportunity for cross-validation by supervisors. ${ }^{4}$ The definition of capital as at end-2010 for the purposes of the BU stress testing exercise follows the FSA guidelines per the interim supervisory framework, which differ in parts from those defined by Basel III (Appendix II).

\section{Each bank submitted a "report card" of the outcome to the FSA, which} subsequently aggregated these results and provided them to the FSAP team on an anonymized basis for further analysis. The analysis estimates changes in potential losses as well as post-shock RWAs and, where applicable, the recapitalization needs of a particular bank (Figures 6-8). The team also met with the risk management team from each bank to discuss the nuances of the results.

\section{The results essentially show that banks hold robust capital positions and would remain well-capitalized and largely profitable under all three adverse scenarios:}

- $\quad$ Capital ratios stay above the respective minimum regulatory requirements.

- The weighted-average capital ratios (total capital, Tier 1 capital and core Tier 1 capital) for the seven banks exceed the Basel III minima by at least 6 percentage points at any time over the stress test horizon (and the FSA Interim Capital Regime requirements by at least 4 percentage points).

- The weighted-average core Tier 1 capital ratio for the aggregated sample stays at or above 8.8 percent (severe double-dip scenario) throughout the stress-test horizon and the average leverage ratio never drops below 4.6 percent.

O On an individual basis, the lowest capital ratios are typically observed in 2013. Under the severe double-dip scenario, the median core Tier 1 ratio drops to

\footnotetext{
${ }^{4}$ For the very high impact banks, supervisory review by the FSA, including rigorous capital stress testing, is undertaken annually. Smaller banks are obliged to submit their ICAAP results to the FSA each year, incorporating the results of their stress testing; the FSA is more likely to review these institutions on a longer cycle.
} 
7.6 percent, largely attributable to high credit losses during the first two years of the stress test horizon. During the same year, the median Tier 1 and total capital ratios are 9.3 and 12.2 percent, respectively.

- Even if voluntary capital buffers of 2.5 percentage points above the total capital ratio and one percentage point above the core Tier 1 and Tier 1 capital ratios are incorporated in the hurdle rates, the potential shortfall in total capital would not exceed $£ 2.1$ billion ( 0.1 percent of GDP) under the severe double-dip scenario.

- $\quad$ The severe double-dip scenario, which is consistent with the FSA's 2011 anchor scenario, has turned out to be the most stringent. The prolonged slow growth scenario does not have as negative an impact as initially anticipated - an outcome that banks attribute to the relatively benign unemployment profile associated with that scenario. Indeed, the impact of prolonged slow growth on all capital components generally appears more benign than that of the mild double-dip recession.

- $\quad$ The diverse operations of the major banks, both across business lines and in terms of their geographic footprints mean that each is exposed to a different set of risks. Almost all banks are most affected by the severe double-dip recession scenario, but the extent of the impact of the other two adverse scenarios appears to depend on their business focus, with retail banks more affected by the mild double-dip recession, while banks with investment banking operations appear more susceptible to the prolonged slow growth scenario. Nonetheless all banks appear to have sufficient capital to absorb the prescribed shocks.

- $\quad$ Aggregated information on common risk drivers suggests that the resilience exhibited - which could be aided by considerable creditor forbearance at some banks - may mask some vulnerabilities. Persistently high credit losses during a recession represent the main risk. ${ }^{5}$ Not surprisingly, retail-focused banks would be hardest hit by any sharp economic downturn. Separately, exchange rate shocks on major currencies and higher risk weights on securitization and counterparty risk exposures under revised regulatory standards are the main contributors to the increase in RWAs for market risk.

\footnotetext{
${ }^{5}$ See also FSAP Technical Note, "Vulnerabilities of Household and Corporate Balance Sheets and Risks for the Financial Sector."
} 
Figure 6. Distribution of Core Tier 1 Capital Ratios from the U.K. FSAP Update Bottom-Up Stress Tests, 2011-15

(In percent)

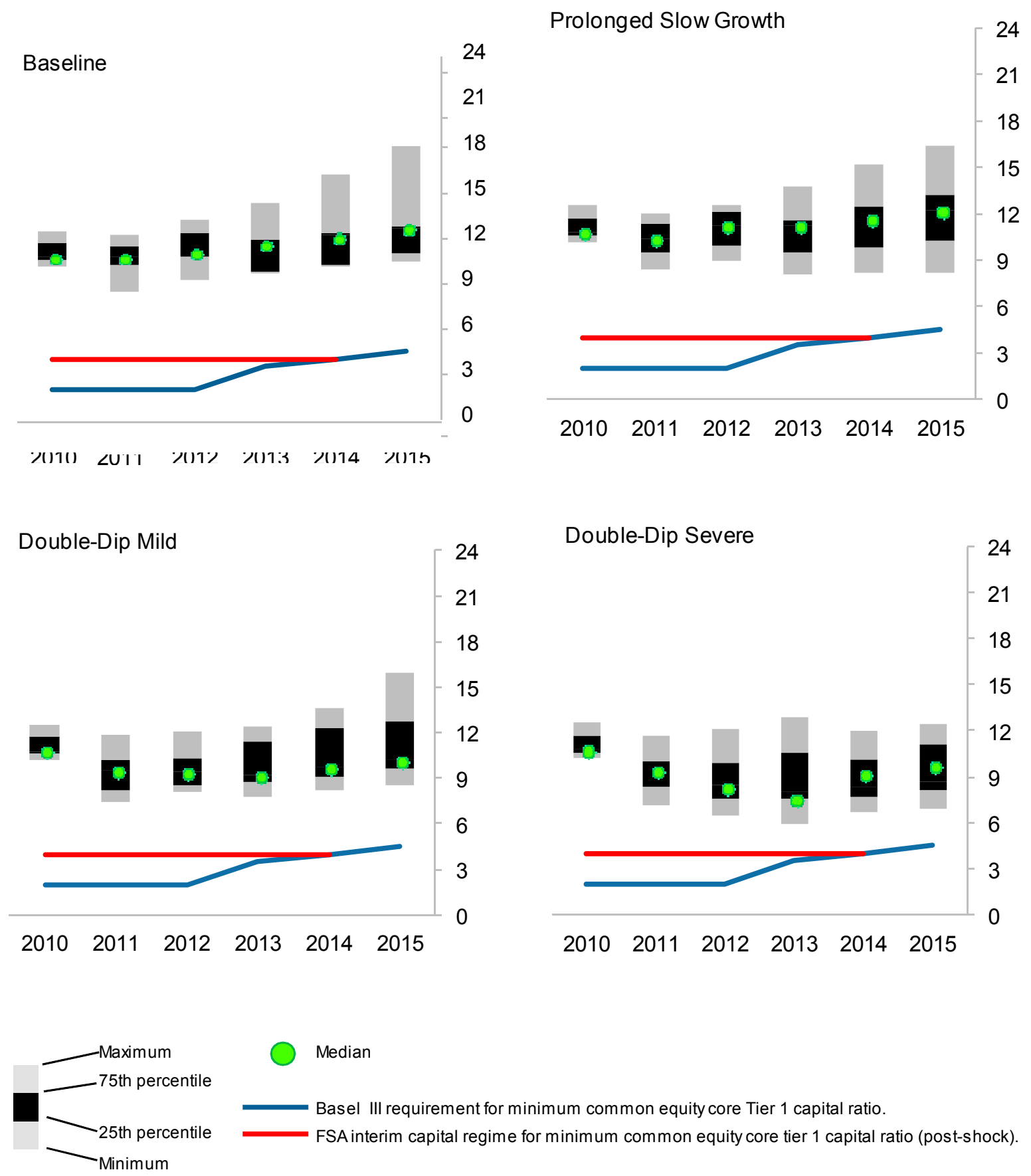

Sources: FSA; major U.K. banks; and IMF staff calculations.

CInternational Monetary Fund. Not for Redistribution 
Figure 7. Distribution of Tier 1 Capital Ratios from the U.K. FSAP Update Bottom-Up Stress Tests, 2011-15

(In percent)
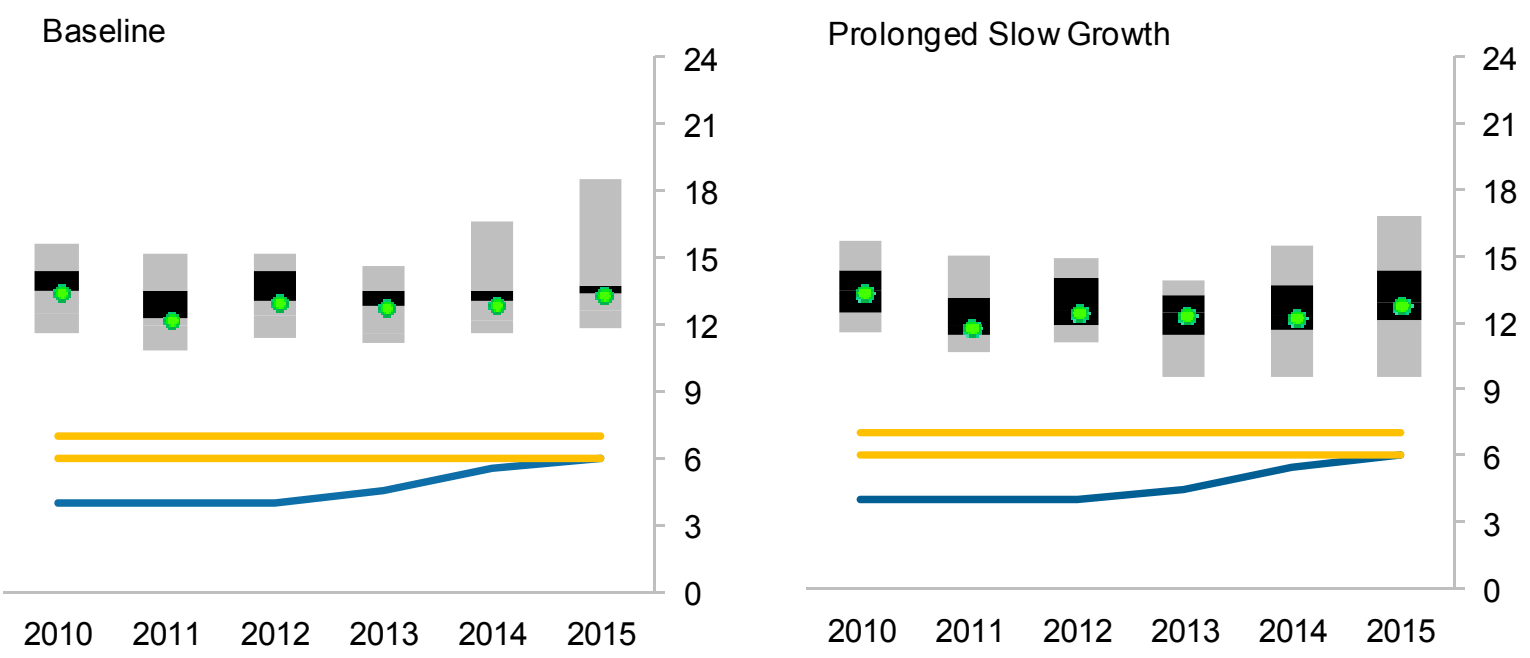

Double Dip Mild

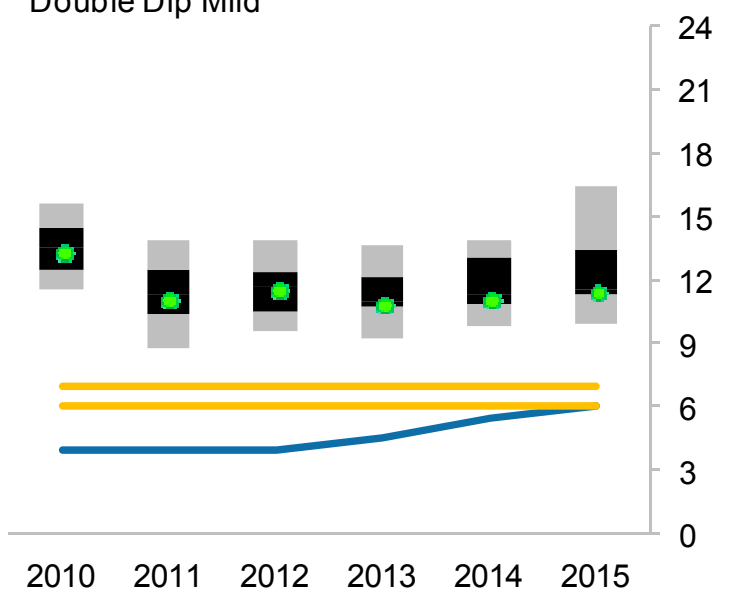

Double Dip Severe

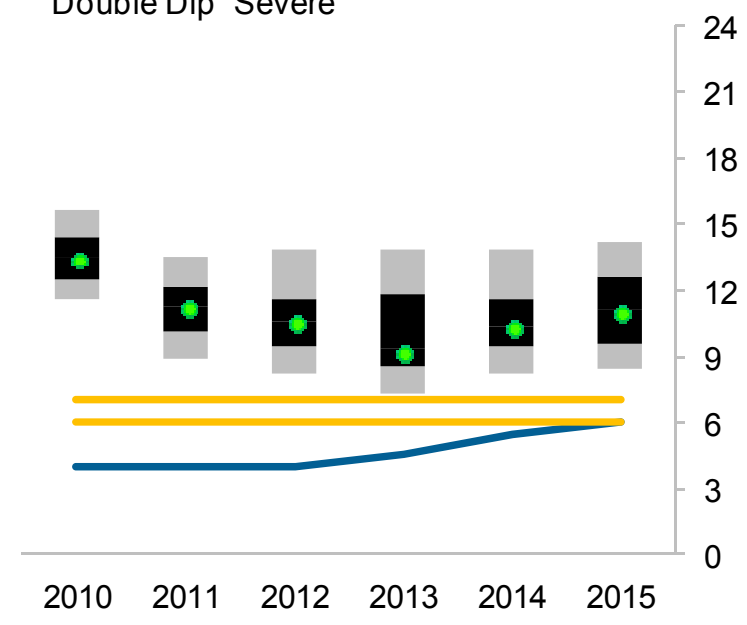

Basel III capital requirement for minimum Tier 1 capital ratio.

FSA Interim Capital Regime "band" for minimum Tier 1 capital ratio (post-shock).

Sources: FSA; major U.K. banks; and IMF staff calculations.

CInternational Monetary Fund. Not for Redistribution 
Figure 8. United Kingdom: Distribution of Total Capital Ratios from the U.K.

FSAP Update Bottom-Up Stress Tests, 2011-15

(In percent)

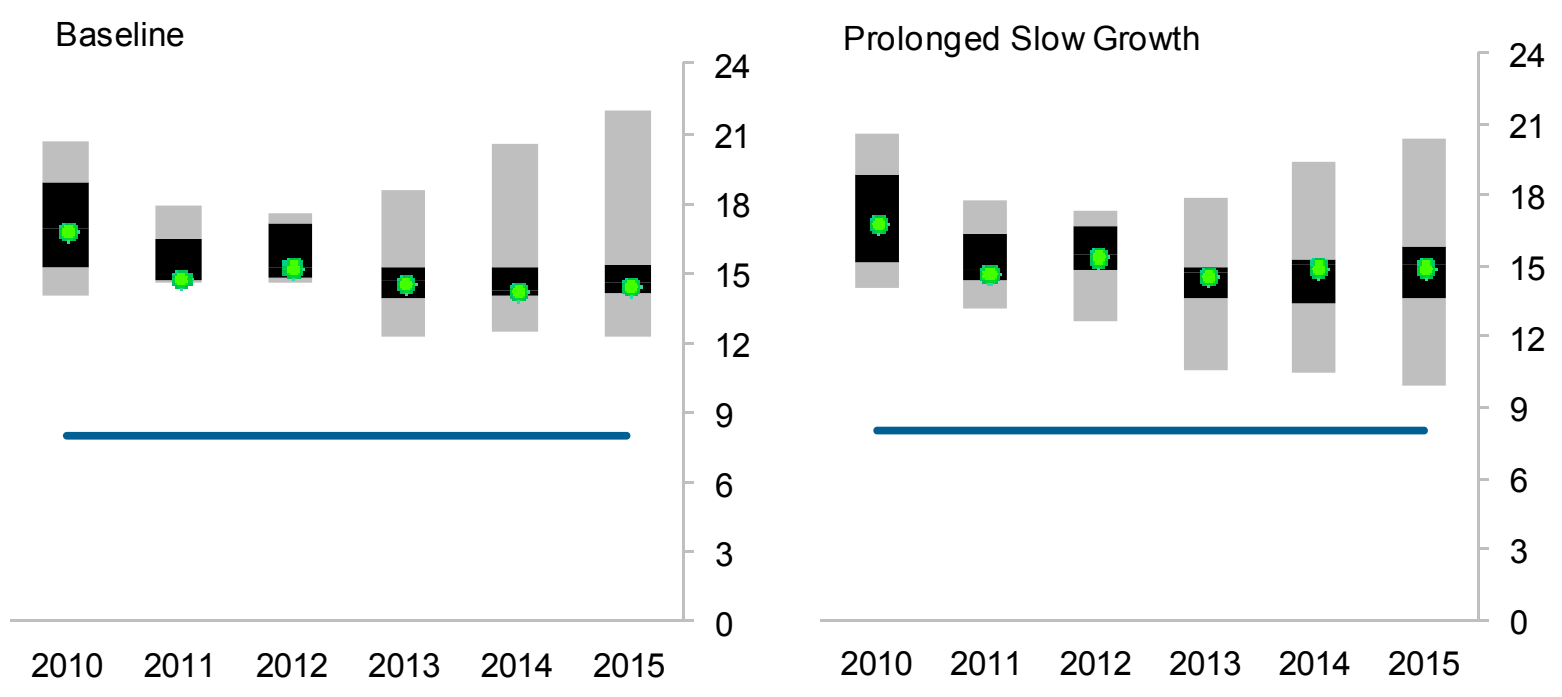

Double Dip Mild

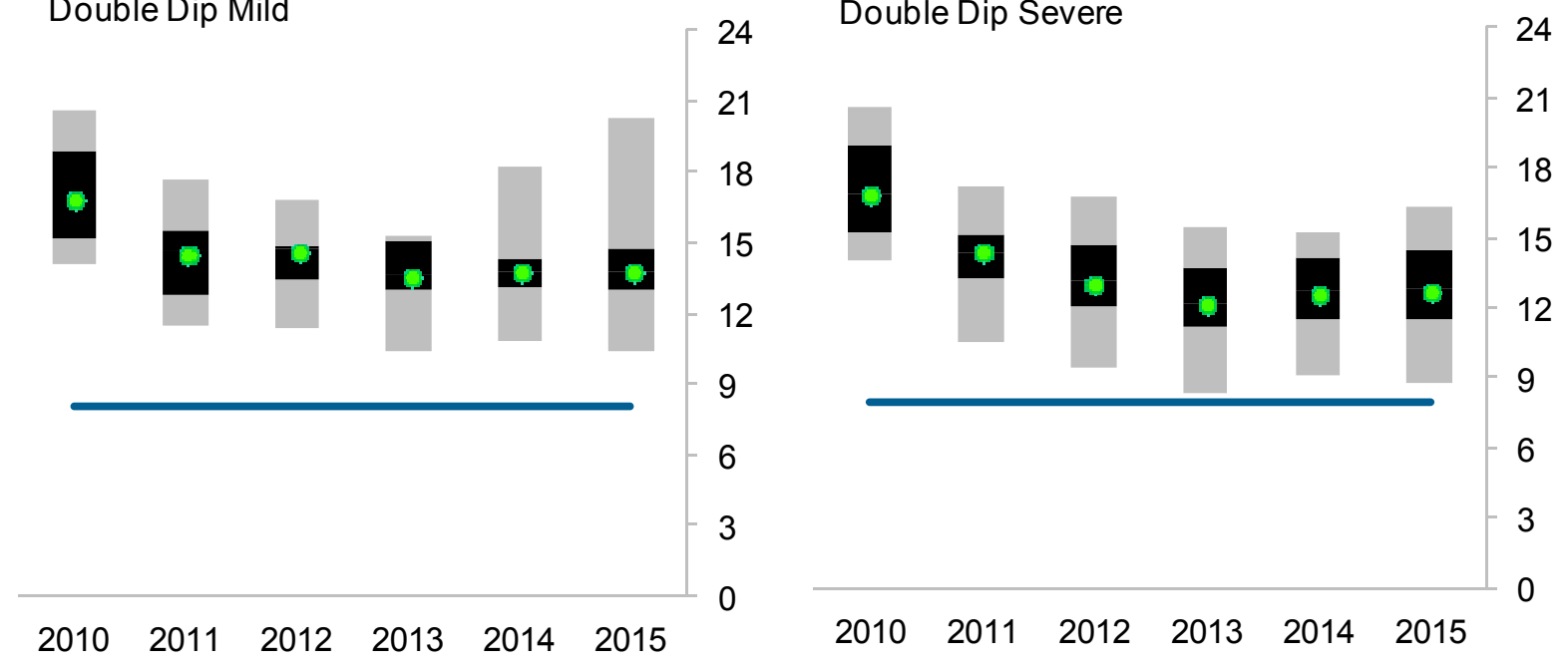

Basel III capital requirement for minimum total capital ratio.

Sources: FSA; major U.K. banks; and IMF staff calculations.

CInternational Monetary Fund. Not for Redistribution 
- $\quad$ The sovereign exposures of the major banks do not appear to represent a major source of risk, unless stresses lead to severe disruptions in wholesale funding markets (see below). In general, banks appear to have significantly reduced their banking book exposures to non-AAA rated sovereign and bank debt by end-2010, leaving their trading books to absorb any potential further haircuts. Under the severe double dip scenario, average potential losses amount to the equivalent of 0.07 percent of 2010 GDP ( $£ 1$ billion) over the stress test horizon, with 2011 losses alone amounting to an equivalent of 0.2 percent of 2010 GDP ( $£ 2.9$ billion) — around 20 percent of the exposure from the previous year's debt holding.

20. Overall, the results confirm the significant recapitalization efforts and the derisking of balance sheets by banks. The latter observation is consistent with the FSAP's own quantitative analysis (see below). However, a possible cumulative increase in RWAs of more than 30 percent over the stress test horizon under each scenario suggests that there may be room for further de-risking of balance sheets, a process that is continuing at present. Discussions with banks on their reverse stress tests reveal that a combination of severe adverse events (e.g., persistently high unemployment, stagflation, rising interest rates, sovereign defaults, geopolitical risks) could lead to solvency concerns. Banks are required to formally incorporate reverse stress tests in the next round of the ICAAP.

\section{B. Top-Down Solvency Stress Tests}

\section{The BoE's RAMSI}

21. RAMSI is used to generate stress estimates for assessing the systemic risk of the five largest U.K. banks, using end-2010 financial data. The model provides a quantitative framework for assessing how shocks transmit through balance sheets (Box 1). It incorporates network interactions and feedback effects arising from both the asset and liability sides of the balance sheets of banks.

\section{RAMSI's satellite models are initially used to generate idiosyncratic variables} from the macro-financial variables derived from the FSA's macro models (Figure 9). The model has at its center a detailed description of each banks' balance sheet and profit and loss account and uses a set of inter-connected modules to analyze banks' dynamic response to a change in macro-financial conditions. Projections of interest income, non-interest income, trading income, operating expenses and credit losses are used as inputs to estimate shocks to capital in RAMSI and as inputs to satellite models underpinning the Systemic CCA stress tests (Figure 10).

23. The stress test results obtained under the RAMSI framework suggest that the largest U.K. banks are resilient even against severe stress (Figures 11-13): 
- $\quad$ The cyclical treatment of projected trading income and a sluggish increase in credit losses are the key risk drivers. The largest impact appears to be on banks with the most diversified business models.

- $\quad$ Although all banks pass the capital hurdle rates under all scenarios, two banks experience a substantial impact on capital in the severe double-dip scenario. Core Tier 1 ratios diverge by as much as 6.2 percentage points from the corresponding baseline scenario, but remain at least 6 percentage points above the relevant hurdle rates.

- In contrast to the BU stress test results, shocks to sovereign and bank debt appear to have greater impact on capital adequacy. When the FSAP's debt haircut methodology is applied to bank holdings of non-AAA rated sovereign and bank debt on both the banking and trading books of banks, potential aggregate capital losses of up to a maximum equivalent to 1.8 percent of 2010 GDP ( $£ 26$ billion) in sovereign and bank debt are estimated under the severe double-dip scenario, in 2011. The combined impact on core Tier 1 capital would be 10 percent, translating to almost a one percentage point decline in the core Tier 1 ratio, still well above the relevant hurdle rates. Over the five-year stress test horizon, the realization of risks to sovereign and bank debt could have an impact averaging the equivalent of 1.7 percent of 2010 GDP (almost $£ 25$ billion).

- $\quad$ The impact of the prolonged slow growth scenario on the banking system appears similar to that of the mild double-dip recession. The distribution by bank differs somewhat between the two, but the median result above the relevant hurdle rates shows a generally consistent trend for each capital ratio. 


\section{Box 1. Overview of the BoE's RAMSI 1/}

RAMSI is a model of the major banks in the U.K. financial system. The model has at its centre a detailed description of each bank's balance sheet and profit and loss account, and uses a set of interconnected modules to analyze banks' dynamic response to a change in macro-financial conditions. The framework also incorporates a network model that captures second-round "contagion" risk stemming from interbank exposures, on both the asset and liability side, and from the interaction between balance sheets and asset prices. 2/

\section{RAMSI produces projections for key banking sector variables conditional on projections for the macro-}

financial environment. RAMSI can generate its own macro-financial projections using a medium-scale Vector Auto-regression,3/ or RAMSI can use macro-financial inputs from another source. For the FSAP, for example, the baseline conditioning paths were taken from the October WEO. A set of independent modules is then used to map these projections into bank-specific profit and loss numbers, focusing on five key headline items: net interest income, credit losses, non-interest income excluding trading income, net trading income and operating expenses. In addition, an asset pricing model is used to estimate any changes in the market value of banks' exposures triggered by changes in equity prices or market interest rates.

These modules are largely based on reduced-form econometric equations. For instance, credit losses are estimated using a system of regressions that link write-off rates on broad asset classes (e.g., domestic mortgages) to a set of empirically relevant macro indicators (e.g., unemployment and house prices). The main exceptions are the net interest income and market value calculations, which rely on a calibrated asset pricing model that incorporates a simple no-arbitrage condition.4/ A key feature of the model is that the spreads on banks' exposures relative to risk-free (government) yields are endogenous and will generally change in response to a macroeconomic shock; as credit losses rise, for example, banks increase the spread on risky lending to corporates and households.

Risk factors and profit and loss numbers are simulated on a quarterly basis, but RAMSI can be run over an arbitrary forecasting horizon because it takes account of the reinvestment of profits between quarters. Box Figure 1 gives a stylized overview of how the reinvestment model is linked to the P\&L projections, and illustrates the key behavioral assumption behind the model.5/

At the beginning of each quarter, each bank's income statement is simulated based on the estimated impact of the chosen macro-financial scenario. Profits are split between tax, dividends and potential retained earnings. Three cases can then arise. If the bank makes a loss, its capital buffer is eroded and the balance sheet shrinks. The process continues until the bank manages to make a profit or breaches the regulatory capital buffer. If the bank's earnings are positive but, given the state of the balance sheet, not sufficient to achieve an exogenously set capital ratio target, the bank retains the earnings entirely to boost capital and only purchases zero-risk weight assets (to ensure the balance sheet balances). It continues to do this in later periods until the target capital ratio is met. Finally, if earnings and existing capital are sufficient to exceed the target, the bank expands its assets to hit the target, holding constant the distribution of assets at the start of the projection.

The upper arrow in the diagram highlights that income in the following period depends on the updated values of assets and liabilities given the flows in the previous period, and given macro-financial conditions at that point. The reinvestment model thus generates a complex feedback loop where the size and composition of the balance sheets is allowed to change dynamically over time. Modeling the reinvestment process is necessary to achieve internal stock-flow consistency. It also implies that banks in RAMSI are not completely passive, although their responses to exogenous shocks are dictated by simple behavioral rules rather than an explicit forward-looking optimization. 


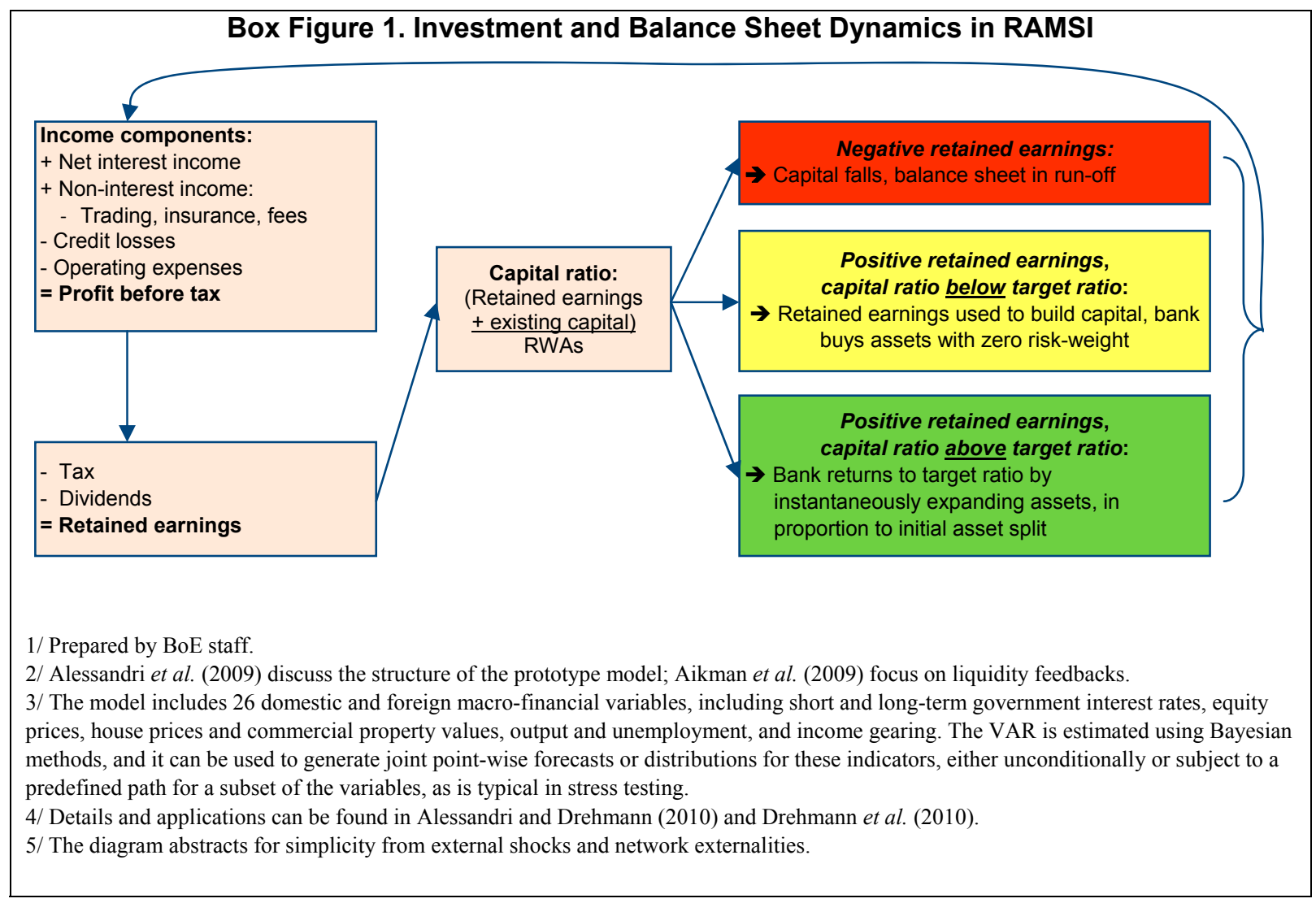


Figure 9. Estimation of Satellite Models in the U.K. FSAP Update Stress Testing Exercise

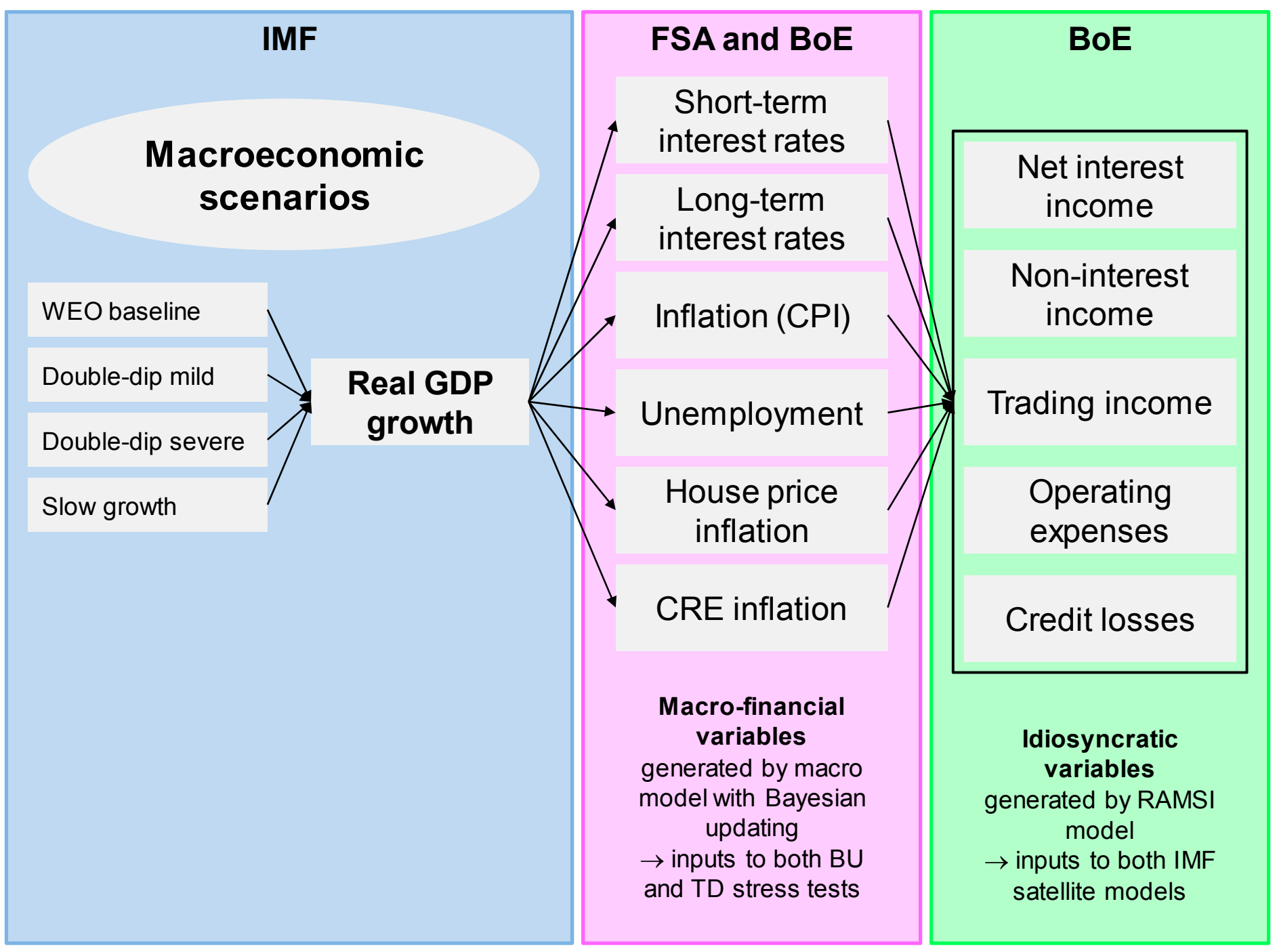


Figure 10. Application of Satellite Output in the RAMSI and the Systemic CCA Stress Tests

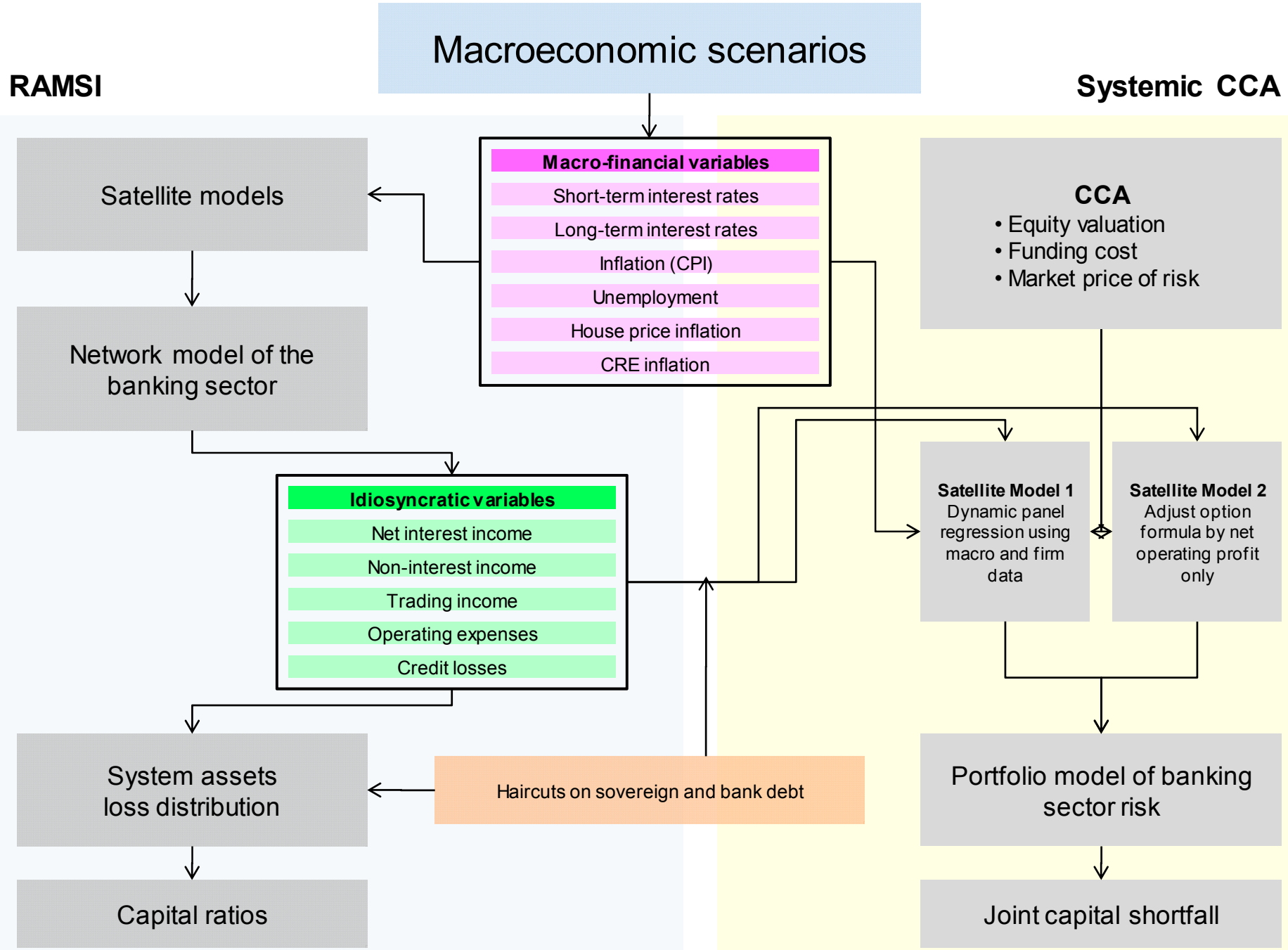


Figure 11. Distribution of Core Tier 1 Capital Ratios from the BoE RAMSI TopDown Stress Tests for the U.K. FSAP Update, 2011-15

(In percent)

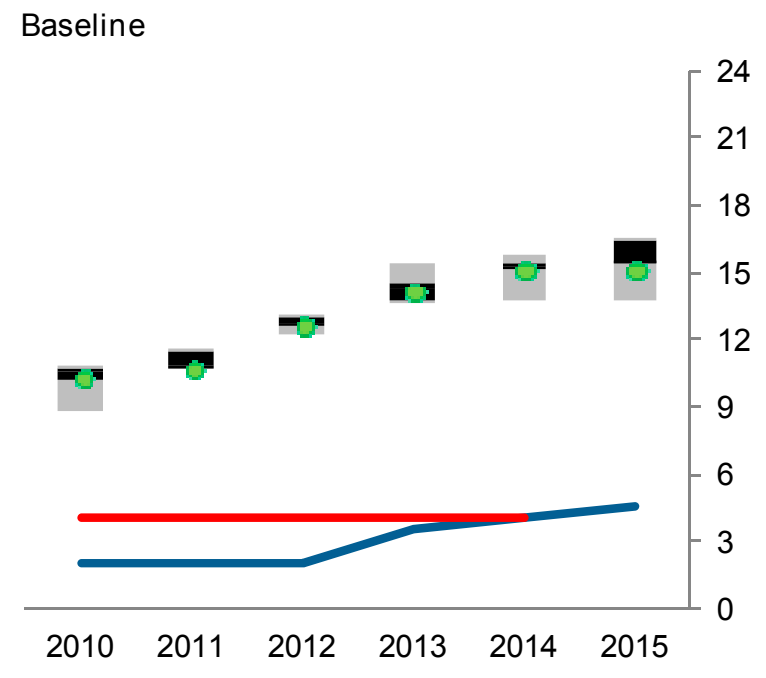

Prolonged Slow Growth

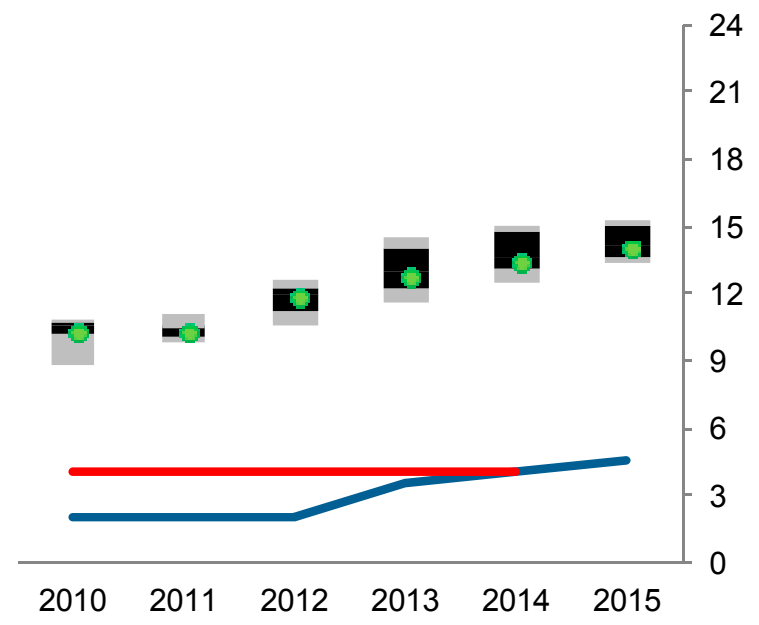

Double-Dip Mild

Double-Dip Severe
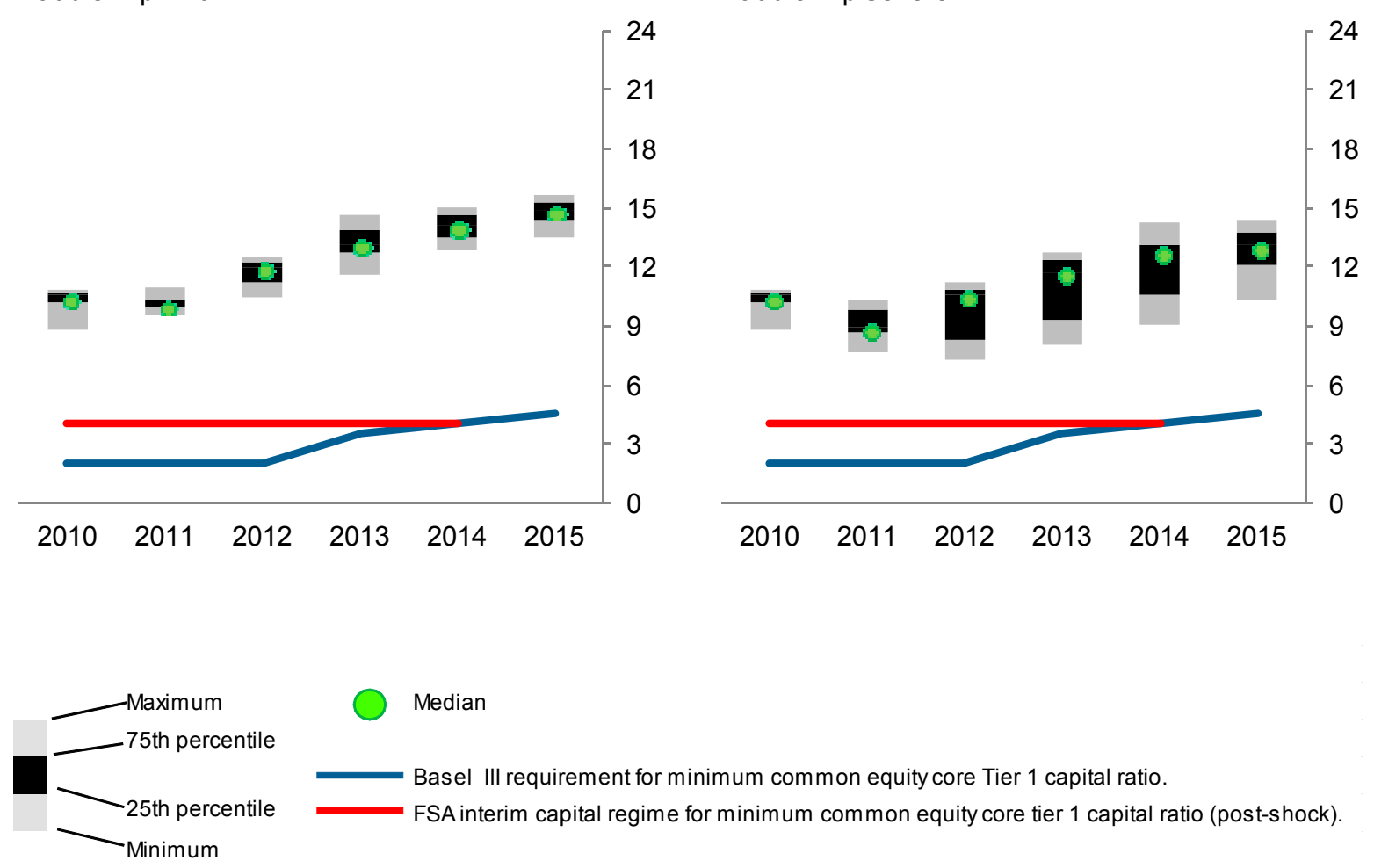

Sources: BoE; and IMF staff calculations.

CInternational Monetary Fund. Not for Redistribution 
Figure 12. United Kingdom: Distribution of Tier 1 Capital Ratios from the BoE RAMSI Top-Down Stress Tests for the U.K FSAP update, 2011-15

(In percent)

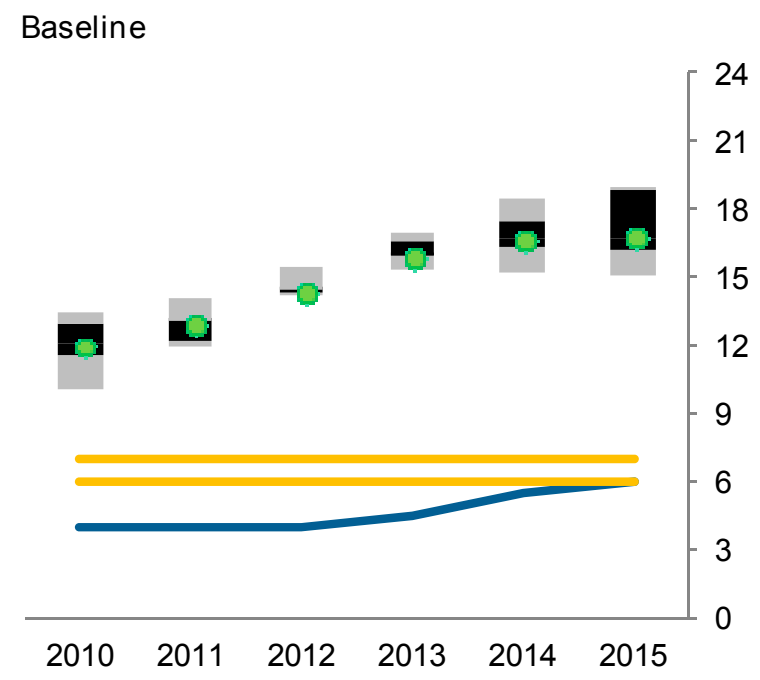

Prolonged Slow Growth

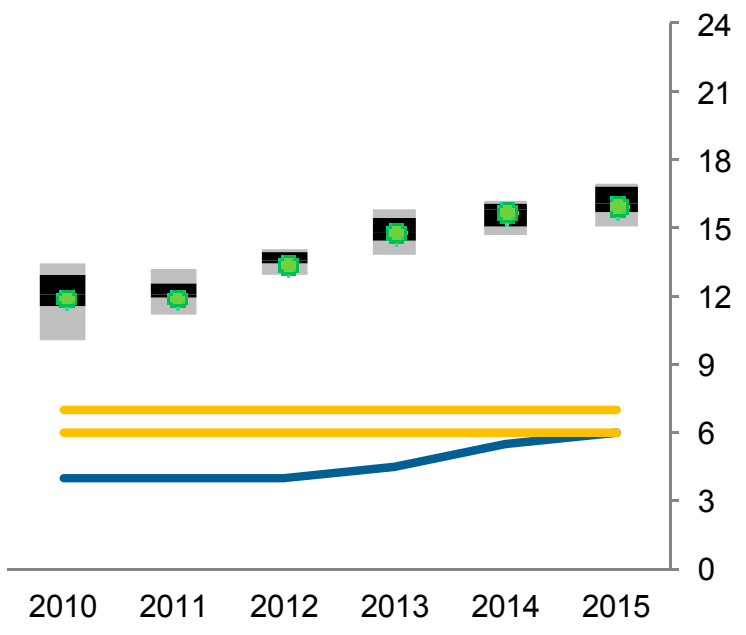

Double-Dip Mild

Double-Dip Severe
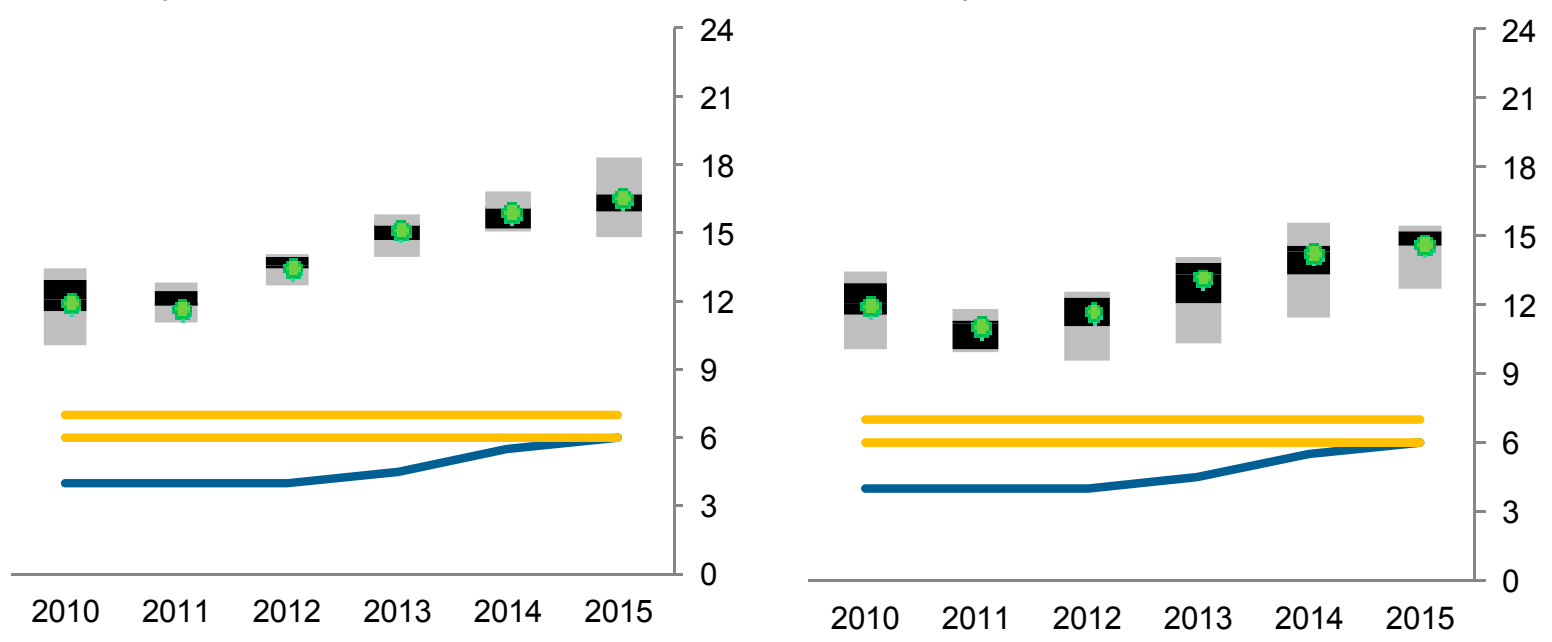

Basel III capital requirement for minimum Tier 1 capital ratio.

FSA Interim Capital Regime "band" for minimum Tier 1 capital ratio (post-shock).

Sources: BoE; and IMF staff calculations.

CInternational Monetary Fund. Not for Redistribution 
Figure 13. United Kingdom: Distribution of Total Capital Ratios from the BoE RAMSI Top-Down Stress Tests for the U.K. FSAP Update, 2011-15

(In percent)
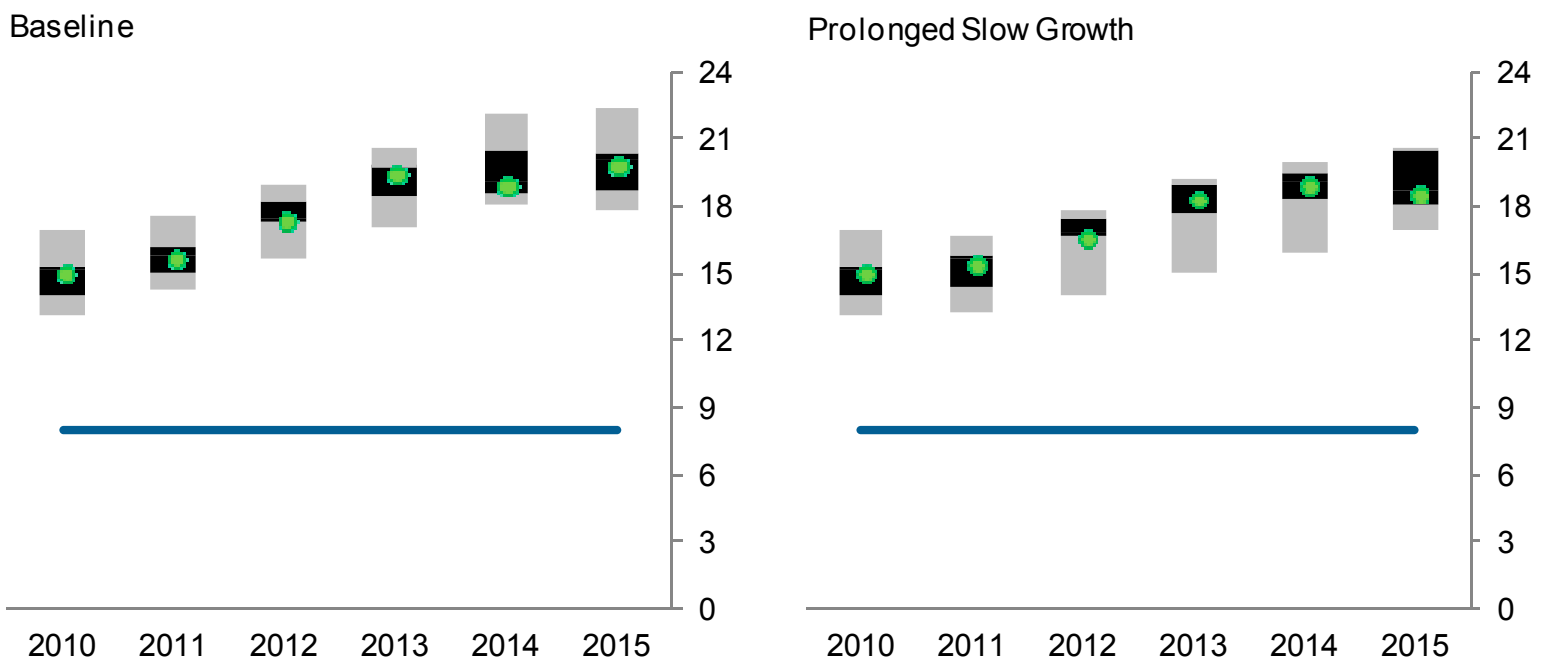

Double-Dip Mild

Double-Dip Severe
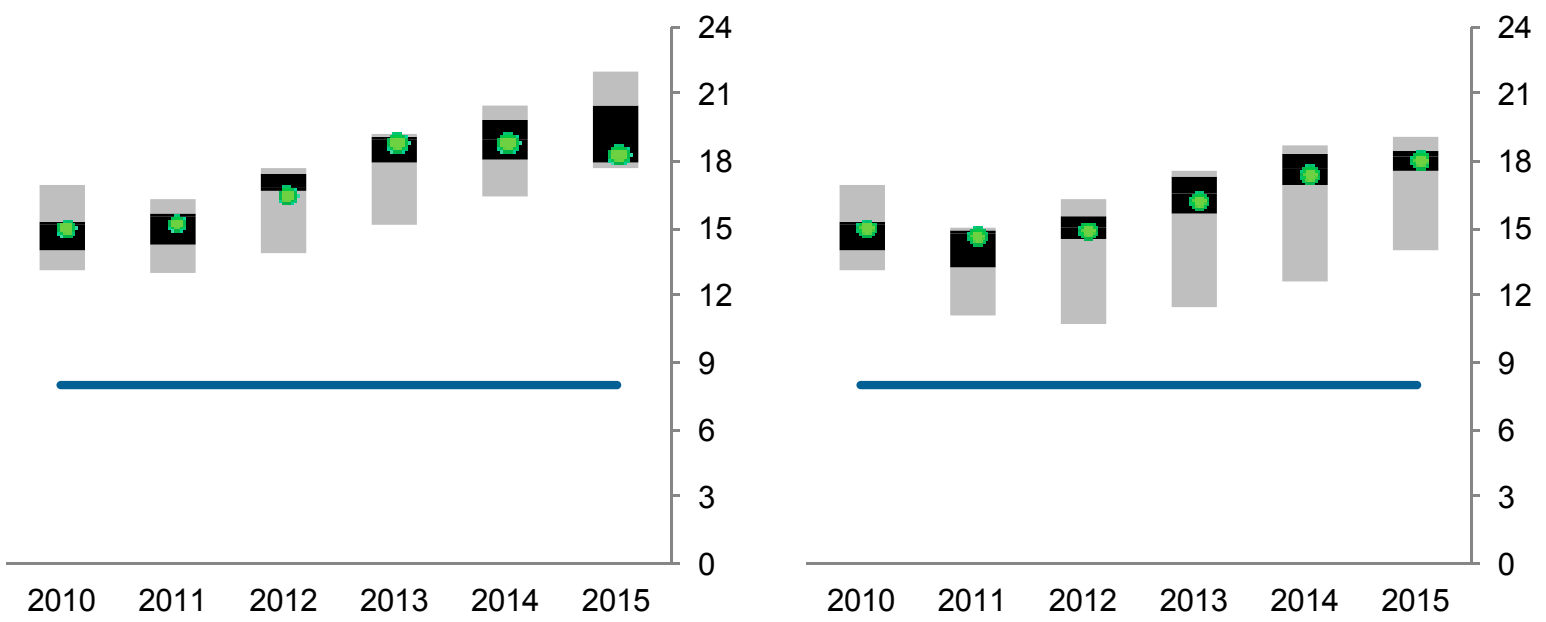

Basel III capital requirement for minimum total capital ratio.

Sources: BoE; and IMF staff calculations.

CInternational Monetary Fund. Not for Redistribution 


\section{The IMF's market-based systemic solvency model}

\section{A second approach to TD stress testing using the Systemic CCA model is} undertaken to estimate systemic solvency risk. The Systemic CCA framework accounts for the dependence among individual banks in estimating the joint market-implied potential losses under systemic distress assumptions in order to estimate the resulting shortfall (Box 2). Under this approach, the banking sector is essentially viewed as a portfolio of individual potential losses, specified as implicit put options with individual risk parameters, whose joint exposure to common risk factors can be accounted for by including their dependence structure (since conventional bivariate correlation is ill-suited for systemic risk analysis when extreme events occur jointly and in a non-linear fashion)

\section{The interdependencies, which proved critical during the crisis, are analyzed} using a forward-looking, market data-based framework. Data from January 2005 to March 2011 are used to estimate the central case (median) market-implied potential capital losses as well as the losses during extreme market stresses at a statistical probability of 5 percent or less (expressed as "tail risk"). ${ }^{6}$ The estimates are then used to determine individual contributions to systemic risk.

\section{Historical shock estimates}

\section{An examination of the historical estimates suggest that only a few banks generated the bulk of systemic risk during the crisis (Table 4):}

- At the time, the escalation of joint solvency stresses was mostly attributable to banks that required government support.

- The contributions of individual banks to both the median and extreme market-implied joint capital loss amounts are consistent with the BU stress test results insofar as the concentration of solvency risks in some banks creates a skewed dispersion.

- $\quad$ The estimated percentage share of systemic risk in different periods of the crisis reveals that at the apex of the credit crisis, the concentration of risks increased beyond the previous average, with the median contribution of under 10 percent of joint capital losses - far below the expected median share of 14.3 percent for the sample of seven banks in a uniform distribution.

- $\quad$ There has been significant de-risking of banks' balance sheets since late-2008.

\footnotetext{
${ }^{6}$ Two types of satellite models have been applied in order to determine the sensitivity of financial sector performance to changes in macroeconomic conditions. Under first approach forecasts of operating profit and credit losses generated in the RAMSI model are incorporated in the structural valuation approach that underpins the Systemic CCA approach.
} 
27. The historical estimates of the joint capital losses are used for stress testing. By modeling how macroeconomic conditions and bank-specific income and loss elements (net interest income, fee income, trading income, operating expenses, and credit losses) have influenced the changes in the financial institutions' market-implied potential losses-as measured by monthly implicit put option values based on an "elevated" default barrier - it is possible to link a particular macroeconomic path (and associated financial sector performance) to potential losses in the future. Alternatively, it is possible to adjust the implied assets of each sample bank by projected profitability in order to determine changes in the put option value underpinning the level of market-implied potential losses. The amount by which the capital losses fall below the defined "distress barrier" represents the potential capital shortfall.

28. Two different methods are thus adopted to model the macro-financial linkages affecting individual potential losses that determine joint capital shortfall under the Systemic CCA approach. Using projections on individual bank performance generated by RAMSI, two types of satellite models are applied for the specification of the macro-financial linkages of any capital shortfall, based on the implied Basel III Tier 1 capital hurdle rates (and compared against the FSA's Interim Capital Regime requirements). For each model, the individually estimated capital loss is aggregated using the Systemic CCA framework with a five-year sliding window and monthly updates over the forecast horizon:

- In the first model ("IMF satellite model"), the historical sensitivity of the marketimplied capital loss is estimated from several macroeconomic variables ${ }^{7}$ (short-term interest rate $[+]$, long-term interest rate [-], real GDP [-], and unemployment $[+])$ and bank-specific variables (net interest income [+], operating profit before taxes [-], credit losses $[+]$, leverage $[+]$, and funding gap $[+]$ ) using a dynamic panel regression specification.

- In the second model ("structural model"), the value of implied assets of each bank as at end-2010 is adjusted by forecasts of operating profit and credit losses generated in the RAMSI model in order to derive a revised put option value (after re-estimating implied asset volatility), which determines the market-implied capital loss.

\section{Central case tail risks}

29. The central case results under Systemic CCA could be considered analogous to those obtained under the BU and RAMSI tests; consistent with those approaches, the Systemic CCA findings are that any impact from the realization of systemic solvency risks would be limited even in a severe recession. After taking into account further

\footnotetext{
${ }^{7}$ The "+/_" signs indicate whether the selected variable exhibit a positive/negative regression coefficient. The statistical significance of model variables was restricted to no more than 10 percent.
} 
declines in the market value of sovereign and bank debt held by the major banks, we find that the joint potential capital loss would be contained under all adverse scenarios and that there would be no capital shortfall (Figure 14 and Table 5):

- $\quad$ Overall, both satellite models yield similar and consistent results despite their rather different specifications. They suggest robustness of estimates under either a panel regression approach or a structural approach via updates of model parameters using forecast changes in profitability.

- $\quad$ Consistent with the findings in the other two stress test approaches, the severe double-dip recession scenario has the biggest impact on the banking system. The impact of the mild double-dip and prolonged slow growth scenarios are almost similar. The banking system remains solvent in all cases.

- $\quad$ Existing capital buffers are sufficient to absorb the realization of central case (median) joint solvency risks. Under baseline conditions, potential joint solvency pressures from the realization of slowing profitability, moderate credit losses and risks to sovereign bank debt holdings would be relatively benign, resulting in joint potential capital losses averaging the equivalent of 0.03 percent of 2010 GDP ( $£ 0.4$ billion) over 2011-15. In the event that the severe double-dip scenario were to be realized, capital losses could amount up to an average 0.12 percent of 2010 GDP (£1.8 billion) over the next five years. The resulting capital balance would remain comfortably above the "distress barrier" under the Basel III capital hurdle rates, and there would be no resulting shortfall. (There would also be no shortfall under the FSA's Interim Capital Regime requirements.)

- As a comparison, perfect correlation of solvency risks across sample banks, as implied by the sum of individual potential losses without taking into account dependence across institutions, could result in larger capital losses albeit still above the required capital adequacy levels. In this case, average capital losses could amount up to 1.1 percent of 2010 GDP ( $£ 15.6$ billion) over the next five years under the severe double-dip scenario with haircuts to sovereign and bank debt, or as low as 0.1 percent of 2010 GDP ( $£ 1.6$ billion ) under the corresponding baseline scenario (Table $6)$.

\section{"Tail of the tail" risks}

30. Although much reduced since the crisis, potential challenges exist from the realization of a very low probability extreme tail risk of multiple banks experiencing a dramatic escalation of losses amid a rapidly deteriorating macroeconomic environment. The Systemic CCA model has the added advantage of estimating a distribution of the potential impact from shocks. Thus, we are able to estimate the outcome of a 5 percent "tail of the tail" risk event (at a very high statistical confidence level beyond the $95^{\text {th }}$ percentile) 
under this method. Under the adverse scenarios, the market-implied capital shortfall would be significantly higher, likely as a result of significantly lower profitability in conjunction with a sharp deterioration in asset quality and weaker fee-based income:

- $\quad$ The extreme tail risk of assumed macro shocks could erode current capital levels to below the distress barrier, resulting in a capital shortfall in the system. A 2 percent probability of a severe double-dip recession scenario beyond the $95^{\text {th }}$ percentile (i.e., a 0.1 percent probability event) could result in average joint capital losses of up to 3.4 percent of 2010 GDP ( $£ 50$ billion), albeit still well below the peaks seen during the crisis (Figure 14). Under this scenario, an average capital shortfall of between 1.3-1.6 percent of 2010 GDP could materialize relative to the Basel III Tier 1 hurdle rates (and 1.6-1.8 percent of 2010 GDP relative to the FSA Interim Capital Regime Tier 1 requirements). At the extreme tail, the prolonged slow growth scenario could yield average joint capital losses of up to 2 percent of GDP ( $£ 29$ billion), which translates to an average shortfall of up to 0.4 percent of 2010 GDP ( $£ 6.3$ billion).

- Depending on the timing and adversity of macroeconomic conditions as well as the evolution of sovereign risk affecting banks' government and bank debt holdings, capital losses could range widely over the five-year horizon. Estimates suggest that potential losses could range between zero (baseline, double-dip mild and double-dip severe without debt haircuts, from 2013 onwards) to an equivalent of between 6.47.1 percent of 2010 GDP (double-dip severe with sovereign and bank debt haircuts in 2011), or £94-104 billion, potentially resulting in an estimated capital shortfall of between 4.4-5.0 percent of GDP, or £63-73 billion, relative to Basel III Tier 1 capital hurdles (and 4.9-5.6 percent of GDP relative to FSA Interim Capital Regime requirements).

\section{An important caveat to the haircuts applied to banks' debt holdings of all non-} AAA rated sovereigns and banks in those countries is that their severity and dynamics are informed by the forward term structure of 5-year sovereign credit default swap (CDS) spreads as at end-2010 (Attachment). Since then, the sovereign CDS spreads for select debtor countries of U.K. banks have increased commensurately with the rising risks to the economic outlook (Figure 15), which are not reflected in the haircuts given the cut-off point for the stress tests. This means that U.K. banks could be affected by additional losseswell beyond the prescribed haircuts projected as at end-2010 — in the event that shocks lead to extreme stresses in the private sector in those countries or in core European banks to which they have large exposures. 


\section{Box 2: Overview of the Systemic CCA Framework}

The Systemic CCA framework can be decomposed into two sequential estimation steps. First, the marketimplied potential losses (and associated change in existing capital levels) are estimated for each sample bank using an advanced form of CCA. Then, these individual estimates are aggregated in a multivariate set-up in order to derivate estimates of joint potential losses and changes in capital levels.

In order to understand individual risk exposures in times of stress, first, CCA is applied to construct riskadjusted (economic) balance sheets of financial institutions (Appendix IV). In its basic concept, CCA quantifies default risk on the assumption that owners of corporate equity in leveraged firms hold a call option on the firm value after outstanding liabilities have been paid off.1/ So, corporate bond holders effectively write a European put option to equity owners, who hold a residual claim on the firm's asset value in non-default states of the world. More specifically, CCA applies this concept to determine the risk-adjusted balance sheet of firms whose assets are stochastic and may be above or below promised payments on debt. When there is a chance of default, the repayment of debt is considered "risky"- to the extent that it is not guaranteed in the event of default. Higher uncertainty about changes in future asset value, relative to the default barrier, increases default risk which occurs when assets decline below the barrier.

In this framework, market-implied potential losses associated with outstanding liabilities can be valued as an implicit put option in the form of a credit spread above the risk-free rate that compensates investors for holding risky debt. The put option value is determined by the duration of the total debt claim, the leverage of the firm, and the volatility of its asset value.2/ The put option was modeled based on a jump diffusion process (Appendix IV) to achieve robust and reliable estimation results in light of empirical shortcomings of the commonly used in the underpinning Merton (1974) model.3/ This approach is an alternative to other proposed extensions aimed at imposing more realistic assumptions, such as the introduction of stationary leverage ratios (Collin-Dufresne and Goldstein, 2001) and stochastic interest rates (Longstaff and Schwartz, 1995).4/

The CCA-generated, market-implied potential losses of individual banks can be transposed into estimates of market-implied potential capital shortfall and generalized to estimates of average and extreme systemwide solvency risk ("joint capital shortfall"). In order to establish greater comparability with balance sheetbased analysis of capital adequacy, the market-implied capital shortfall is estimated as the marginal change of the put option value after a graduated percentage point increase of the total debt claim in each year of the forecast horizon, in line with Tier 1 capital requirements under the current Basel III proposal (so that the "default barrier" becomes a "distress barrier"). So in each case, capital shortfall is derived as the marginal increase of potential losses below a default barrier that includes a capital level commensurate to the minimum

Tier 1 capital ratio (which is viewed as proxy for the market-implied capital level).5/ Then the Systemic CCA approach (Gray and Jobst, 2010 and forthcoming; Gray and others, 2010; see Appendix V) is applied to derive point estimates6/ of the market-implied joint capital shortfall from the multivariate density of each bank's individual marginal distribution of market-implied capital shortfalls (if any) and their dependence structure among all sample banks.

This approach can also be used to quantify the contribution of banks to systemic (solvency) risk (at different levels of statistical confidence) as measured by the market-implied joint capital shortfall. The joint capital shortfall can be written as a linear combination of individual shortfall amounts of banks, whose relative weights (in the weighted sum) are given by the second order cross-partial derivatives of the inverse of the joint probability density function to changes in both the dependence function and individual capital shortfalls. Thus, the contribution can be derived as the partial derivative of the multivariate density to changes in the relative weight of the univariate marginal distribution of individual capital shortfall and its impact on the dependence function (of all capital shortfalls of sample banks) at the specified percentile. 
1/ Shareholders also have the option to default if their firm's asset value ("reference asset") falls below the present value of the notional amount of outstanding debt ("strike price") owed to bondholders at maturity. Bond holders receive a put option premium in the form of a credit spread above the risk-free rate in return for holding risky corporate debt (and bearing the potential loss) due to the limited liability of equity owners.

2/ The value of the put option is subject three principles: (i) the values of liabilities (equity and debt) are derived from assets; (ii) liabilities have different priority (i.e., senior and junior claims); and (iii) assets follow a stochastic process.

3/ The Merton model has shown to consistently under-predict spreads (Jones and others, 1984; Ogden, 1987; Lyden and Saranti, 2000), with more recent studies pointing to considerable pricing errors due to its simplistic nature (Eom and others, 2004).

4/ Incorporating early default (Black and Cox, 1976) does not represent a useful extension in this context given the short estimation and forecasting time window used for the CCA analysis.

5/ The market value of equity is considered equivalent to core capital since CCA does not specify reported capital tiers but implicitly assumes that any potential loss first affects the most junior claims on bank assets (i.e., common equity). However, cross-sectional differences in the quality of capital will affect changes in valuation, which affects the accuracy of individual estimates of market-implied capital shortfall. Limited availability of market data on two banks in the FSAP stress tests means that additional calculations for the estimation of market-implied potential losses and capital shortfall on an individual basis are necessary. Since Santander U.K. and Nationwide are not listed companies, the implied asset values and asset volatilities underpinning the CCA model have to be derived via peer group analysis and historical balance sheet data. Implied assets for Nationwide are derived from quarterly reported total assets, scaled by the median ratio between the individual option-derived implied asset value (Appendix IV, Appendix Box 1) and quarterly reported total assets over the five sample banks with available equity prices. Its historical asset volatility (estimated via a simple GARCH $(1,1)$ specification using total assets is estimated at quarterly frequency and interpolated for daily values by using the dynamics from the median asset volatility of sample banks. For Santander, the implied asset values of the parent company are re-scaled using balance sheet data for the U.K. operations of the bank in order to obtain the implied assets of Santander U.K.. Similarly, the implied asset volatility is obtained after adjusting for the non-linear relationship between assets and asset volatility.

6/ Since point estimates of systemic risk are derived from a time-varying multivariate distribution, it is more comprehensive than the current exposition of both CoVaR (Adrian and Brunnermeier, 2008) and Marginal Expected Shortfall (MES) (Acharya and others, 2009) (as well as extensions thereof, such as Huang and others, 2009). 
Figure 14. Systemic CCA Estimates of the Market-Implied Joint Capital Losses from the U.K. FSAP Update Top-Down Stress Tests, Historical and Potential (with IMF Satellite Model)

(In billions of pound sterling)

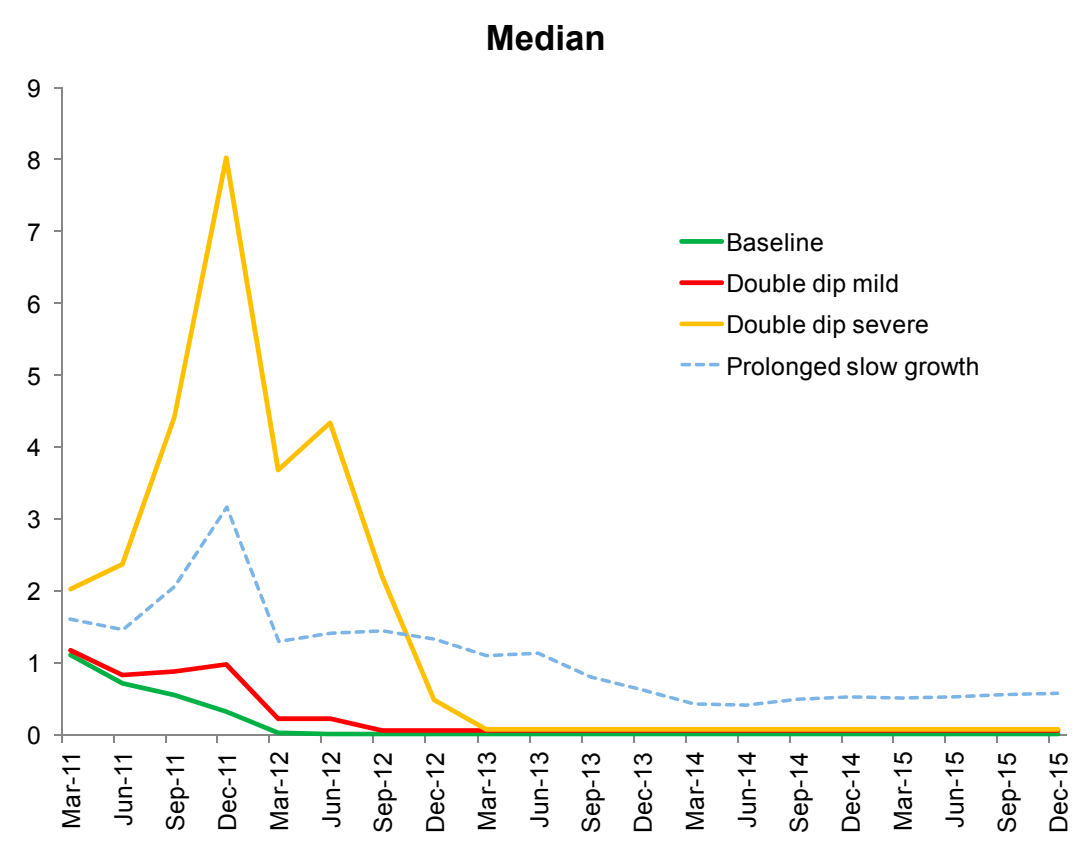

$95^{\text {th }}$ Percentile ("Tail Risk")

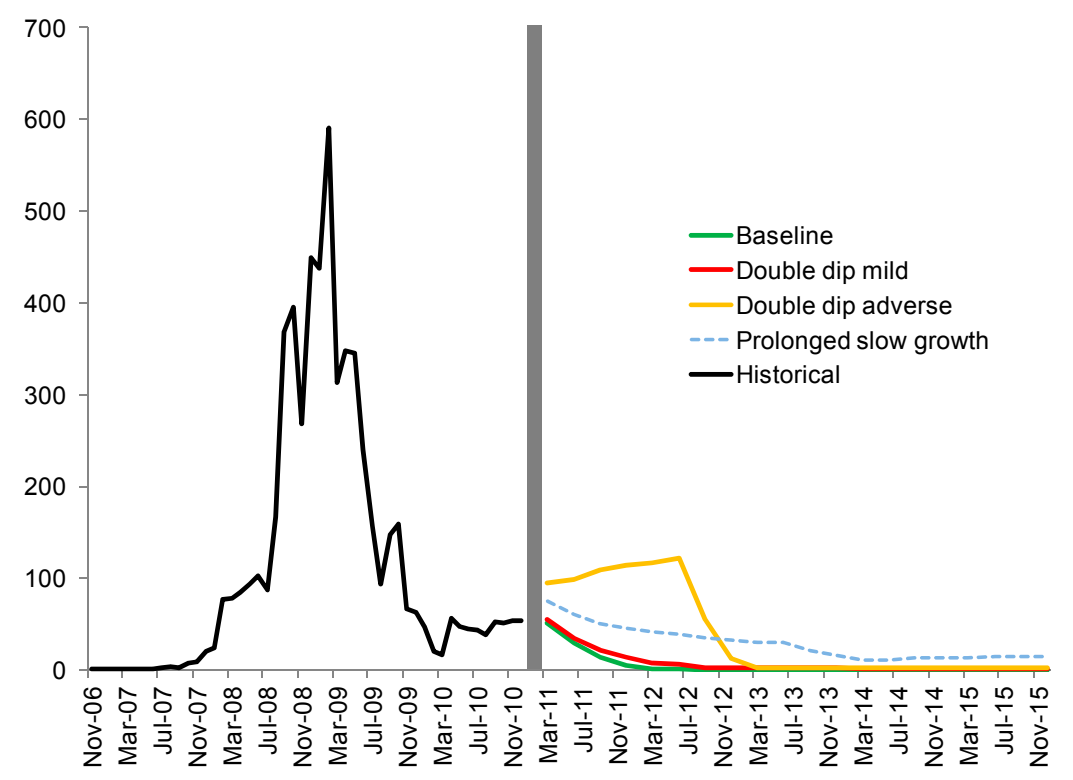

Source: IMF staff calculations.

CInternational Monetary Fund. Not for Redistribution 
Table 4. United Kingdom: Individual Contributions of Large Banks to Systemic Risk during the Crisis-MarketImplied Joint Capital Losses

(Average per time period, in percent of joint capital shortfall)

\begin{tabular}{|c|c|c|c|c|c|c|}
\hline $\begin{array}{c}\text { Pre-Crisis: } \\
\text { End-June 2005- } \\
\text { End-June } 2007\end{array}$ & $\begin{array}{c}\text { Subprime Crisis: } \\
\text { Jul 1, 2007- } \\
\text { Sep 14, } 2008\end{array}$ & $\begin{array}{c}\text { Crisis Period 1: } \\
\text { Sep 15-Dec 31, } \\
2008\end{array}$ & $\begin{array}{c}\text { Crisis Period 2: } \\
\text { Jan 1-Sep 30, } \\
2009\end{array}$ & $\begin{array}{c}\text { Crisis Period 3: } \\
\text { Oct 1, 2009- } \\
\text { Feb 28, 2010 }\end{array}$ & $\begin{array}{c}\text { Sovereign Crisis: } \\
\text { Mar 1, 2010- } \\
\text { Mar } 2011\end{array}$ & Average \\
\hline
\end{tabular}

Expected Joint Capital Shortfall (Median) 1/

\begin{tabular}{|c|c|c|c|c|c|c|c|}
\hline Minimum & 0.1 & 0.3 & 0.8 & 0.6 & 0.2 & 1.0 & 0.4 \\
\hline 25th percentile & 2.4 & 1.5 & 1.8 & 1.5 & 2.1 & 2.6 & 2.0 \\
\hline Median & 5.8 & 4.9 & 3.1 & 4.5 & 6.8 & 8.1 & 5.7 \\
\hline 75th percentile & 15.3 & 16.0 & 6.8 & 20.0 & 21.8 & 22.1 & 17.2 \\
\hline \multirow[t]{2}{*}{ Maximum } & 58.9 & 59.9 & 79.0 & 51.9 & 45.2 & 41.4 & 55.3 \\
\hline & \multicolumn{7}{|c|}{ Extreme Joint Capital Shortfall (95th Percentile) 1/ } \\
\hline Minimum & 0.1 & 0.4 & 1.4 & 1.0 & 0.6 & 1.1 & 0.6 \\
\hline 25th percentile & 3.6 & 2.9 & 4.3 & 3.2 & 2.9 & 4.8 & 3.6 \\
\hline Median & 7.4 & 7.3 & 6.2 & 6.5 & 4.9 & 9.5 & 7.5 \\
\hline 75th percentile & 14.0 & 19.1 & 13.4 & 14.0 & 16.0 & 20.3 & 16.2 \\
\hline Maximum & 57.2 & 48.4 & 56.9 & 58.0 & 56.7 & 39.3 & 52.2 \\
\hline
\end{tabular}

Source: IMF staff calculations.

1/ Each bank's percentage share is based on its time-varying contribution to the multivariate density of potential losses at the $50^{\text {th }}$ (median) and $95^{\text {th }}$ percentiles. The multivariate probability distribution is generated from univariate marginals (based on generalized extreme value assumption) and a time-varying dependence structure. 


\section{Table 5. Systemic CCA Estimates of the Market-Implied Joint Potential Capital Loss and Resulting Shortfall from the U.K. FSAP Update Top-Down Stress Tests, 2011-15}

(Average over time period, in billions of pound sterling unless stated otherwise)

\begin{tabular}{|c|c|c|c|c|c|c|c|c|c|c|c|c|c|c|c|c|}
\hline \multirow[t]{3}{*}{ Forecast Period } & \multirow{2}{*}{\multicolumn{8}{|c|}{$\begin{array}{l}\text { IMF Satellite Model 1/ } \\
\end{array}$}} & \multicolumn{8}{|c|}{ Structural Model $2 /$} \\
\hline & Without & vereign an & & & & ereign and & BankDebt & aircuts & Without & \multirow{2}{*}{\multicolumn{3}{|c|}{ Adverse Scenarios }} & Withs & \multirow{2}{*}{\multicolumn{3}{|c|}{ Adverse Scenarios }} \\
\hline & Baseline & \multicolumn{3}{|c|}{ Adverse Scenarios } & Baseline & \multicolumn{3}{|c|}{ Adverse Scenarios } & Baseline & & & & Baseline & & & \\
\hline & \multicolumn{16}{|c|}{ Market-Implied Joint Potential Capital Loss } \\
\hline & \multicolumn{16}{|c|}{ Median } \\
\hline 2011-15 & 0.13 & 0.20 & 1.35 & 0.67 & 0.14 & 0.26 & 1.43 & 1.07 & 0.43 & 0.62 & 0.98 & 0.71 & 0.48 & 1.04 & 1.77 & 0.98 \\
\hline In percent of GDP & 0.01 & 0.01 & 0.09 & 0.05 & 0.01 & 0.02 & 0.10 & 0.07 & 0.03 & 0.04 & 0.07 & 0.05 & 0.03 & 0.07 & 0.12 & 0.07 \\
\hline 2011 & 0.66 & 0.91 & 4.13 & 1.65 & 0.67 & 0.97 & 4.21 & 2.08 & 0.90 & 1.35 & 1.94 & 1.20 & 1.00 & 1.92 & 2.96 & 1.53 \\
\hline 2013 & 0.00 & 0.00 & 0.00 & 0.52 & 0.01 & 0.06 & 0.08 & 0.92 & 0.27 & 0.37 & 0.61 & 0.50 & 0.30 & 0.74 & 1.33 & 0.73 \\
\hline 2014 & 0.00 & 0.00 & 0.00 & 0.08 & 0.01 & 0.06 & 0.08 & 0.46 & 0.30 & 0.42 & 0.54 & 0.61 & 0.33 & 0.80 & 1.20 & 0.86 \\
\hline \multirow[t]{2}{*}{2015} & 0.00 & 0.00 & 0.00 & 0.16 & 0.01 & 0.06 & 0.08 & 0.54 & 0.30 & 0.34 & 0.41 & 0.59 & 0.33 & 0.64 & 0.94 & 0.83 \\
\hline & \multicolumn{16}{|c|}{95 Percent (Tail Risk) $3 /$} \\
\hline 2011-15 & 4.91 & 6.42 & 35.08 & 18.55 & 5.18 & 8.01 & 37.21 & 29.02 & 12.29 & 17.84 & 28.04 & 19.99 & 13.71 & 29.61 & 49.86 & 27.32 \\
\hline In percent of GDP & 0.34 & 0.44 & 2.41 & 1.28 & 0.36 & 0.55 & 2.56 & 2.00 & 0.85 & 1.23 & 1.93 & 1.38 & 0.94 & 2.04 & 3.43 & 1.88 \\
\hline 2011 & 24.39 & 29.58 & 101.46 & 46.88 & 24.69 & 31.16 & 103.60 & 57.80 & 28.56 & 42.68 & 61.46 & 37.97 & 31.71 & 60.83 & 93.68 & 48.42 \\
\hline 2012 & 0.13 & 2.53 & 73.94 & 26.22 & 0.43 & 4.18 & 76.15 & 37.07 & 10.31 & 17.02 & 38.30 & 17.65 & 11.76 & 30.56 & 65.12 & 25.17 \\
\hline 2013 & 0.00 & 0.00 & 0.00 & 13.61 & 0.27 & 1.63 & 2.19 & 24.10 & 6.97 & 9.73 & 15.88 & 13.05 & 7.85 & 19.42 & 34.93 & 19.04 \\
\hline 2014 & 0.00 & 0.00 & 0.00 & 1.95 & 0.26 & 1.57 & 2.10 & 12.04 & 7.85 & 10.97 & 14.00 & 15.90 & 8.68 & 20.67 & 31.21 & 22.38 \\
\hline \multirow{2}{*}{2015} & \multicolumn{16}{|c|}{ Market-Implied Joint Potential Capital Shortfall } \\
\hline & \multicolumn{16}{|c|}{ Median } \\
\hline 2011-15 & 0.00 & 0.00 & 0.00 & 0.00 & 0.00 & 0.00 & 0.00 & 0.00 & 0.00 & 0.00 & 0.00 & 0.00 & 0.00 & 0.00 & 0.00 & 0.00 \\
\hline In percent of GDP & 0.00 & 0.00 & 0.00 & 0.00 & 0.00 & 0.00 & 0.00 & 0.00 & 0.00 & 0.00 & 0.00 & 0.00 & 0.00 & 0.00 & 0.00 & 0.00 \\
\hline 2011 & 0.00 & 0.00 & 0.00 & 0.00 & 0.00 & 0.00 & 0.00 & 0.00 & 0.00 & 0.00 & 0.00 & 0.00 & 0.00 & 0.00 & 0.00 & 0.00 \\
\hline 2012 & 0.00 & 0.00 & 0.00 & 0.00 & 0.00 & 0.00 & 0.00 & 0.00 & 0.00 & 0.00 & 0.00 & 0.00 & 0.00 & 0.00 & 0.00 & 0.00 \\
\hline 2013 & 0.00 & 0.00 & 0.00 & 0.00 & 0.00 & 0.00 & 0.00 & 0.00 & 0.00 & 0.00 & 0.00 & 0.00 & 0.00 & 0.00 & 0.00 & 0.00 \\
\hline 2014 & 0.00 & 0.00 & 0.00 & 0.00 & 0.00 & 0.00 & 0.00 & 0.00 & 0.00 & 0.00 & 0.00 & 0.00 & 0.00 & 0.00 & 0.00 & 0.00 \\
\hline \multirow[t]{2}{*}{2015} & 0.00 & 0.00 & 0.00 & 0.00 & 0.00 & 0.00 & 0.00 & 0.00 & 0.00 & 0.00 & 0.00 & 0.00 & 0.00 & 0.00 & 0.00 & 0.00 \\
\hline & \multicolumn{16}{|c|}{95 Percent (Tail Risk) $3 /$} \\
\hline 2011-15 & 0.00 & 0.00 & 22.61 & 3.30 & 0.00 & 0.00 & 23.48 & 6.28 & 0.00 & 2.08 & 7.48 & 1.52 & 0.00 & 5.71 & 19.40 & 3.61 \\
\hline In percent of GDP & 0.00 & 0.00 & 1.56 & 0.23 & 0.00 & 0.00 & 1.62 & 0.43 & 0.00 & 0.14 & 0.51 & 0.10 & 0.00 & 0.39 & 1.33 & 0.25 \\
\hline 2011 & 0.00 & 0.00 & 71.20 & 16.49 & 0.00 & 0.00 & 73.34 & 27.41 & 0.00 & 10.40 & 31.19 & 7.58 & 0.00 & 28.55 & 63.42 & 18.03 \\
\hline 2012 & 0.00 & 0.00 & 41.84 & 0.00 & 0.00 & 0.00 & 44.05 & 3.98 & 0.00 & 0.00 & 6.20 & 0.00 & 0.00 & 0.00 & 33.02 & 0.00 \\
\hline 2013 & 0.00 & 0.00 & 0.00 & 0.00 & 0.00 & 0.00 & 0.00 & 0.00 & 0.00 & 0.00 & 0.00 & 0.00 & 0.00 & 0.00 & 0.54 & 0.00 \\
\hline 2014 & 0.00 & 0.00 & 0.00 & 0.00 & 0.00 & 0.00 & 0.00 & 0.00 & 0.00 & 0.00 & 0.00 & 0.00 & 0.00 & 0.00 & 0.00 & 0.00 \\
\hline 2015 & 0.00 & 0.00 & 0.00 & 0.00 & 0.00 & 0.00 & 0.00 & 0.00 & 0.00 & 0.00 & 0.00 & 0.00 & 0.00 & 0.00 & 0.00 & 0.00 \\
\hline
\end{tabular}

Source: IMF staff calculations.

Note: The estimations show the joint capital requirements for maintaining the market value of Tier 1 capital, with a gradual increase of the hurdle rate from 2013 onwards consistent with the Basel III proposal as at December 2010.

1/ The IMF satellite model uses a set of macroeconomic variables (short-term interest rates, long-term interest rates, real GDP growth, and unemployment) as well as income elements specific to each bank (operating profit, net interest income) to project potential losses generated by the CCA methodology.

2/ As an alternative, projected operating profit based on RAMSI model results is integrated in the CCA framework by adjusting implied bank assets, which increase potential losses via an option pricing approach. The treatment of losses from haircuts on holdings of sovereign and bank debt differs between both satellite model approaches. In the case of the former, these losses are calculated each year and added to the estimated overall potential losses. In contrast, for the alternative satellite model, losses from these debt holdings are subtracted from the RAMSI-model projected operating profit each quarter.

$3 /$ The tail risk at the 95th percentile represents the average probability density beyond the 95th percentile as a threshold level. 
Table 6. Systemic CCA Estimates of the Market-Implied Total Potential Capital Loss from the U.K. FSAP Update Top-Down Stress Tests, 2011-15

(Average over time period, in billions of pound sterling unless stated otherwise)

\begin{tabular}{|c|c|c|c|c|c|c|c|c|c|c|c|c|c|c|c|c|}
\hline \multirow{5}{*}{$\begin{array}{l}\text { Forecast } \\
\text { Period }\end{array}$} & \multicolumn{16}{|c|}{ Sum of Individual Potential Capital Losses } \\
\hline & \multicolumn{8}{|c|}{ IMF Satellite Model 1/ } & \multicolumn{8}{|c|}{ Alternative Satellite Model with RAMSI-based profit forecast 2I } \\
\hline & \multicolumn{4}{|c|}{ Without sovereign/bank debt haircuts } & \multicolumn{4}{|c|}{ With sovereign/bank debt haircuts } & \multirow{2}{*}{\multicolumn{4}{|c|}{$\begin{array}{l}\text { Without sovereign/bank debt haircuts } \\
\text { Baseline }\end{array}$}} & \multicolumn{4}{|c|}{ With sovereign/bank debt haircuts } \\
\hline & \multirow[t]{2}{*}{ Baseline } & \multicolumn{3}{|c|}{ Adverse Scenarios } & \multirow[t]{2}{*}{ Baseline } & \multicolumn{3}{|c|}{ Adverse Scenarios } & & & & & \multirow[t]{2}{*}{ Baseline } & \multicolumn{3}{|c|}{ Adverse Scenarios } \\
\hline & & DD Mild & DD Severe & SG & & DD Mild & DD Severe & SG & Baseline & DD Mild & DD Severe & SG & & DD Mild & DD Severe & SG \\
\hline 2011-15 & 1.54 & 2.01 & 10.97 & 5.80 & 1.62 & 2.51 & 11.64 & 9.08 & 3.84 & 5.58 & 8.77 & 6.25 & 4.29 & 9.26 & 15.59 & 8.54 \\
\hline In percent of GDP & 0.11 & 0.14 & 0.75 & 0.40 & 0.11 & 0.17 & 0.80 & 0.62 & 0.26 & 0.38 & 0.60 & 0.43 & 0.29 & 0.64 & 1.07 & 0.59 \\
\hline 2011 & 7.64 & 9.26 & 31.73 & 14.67 & 7.73 & 9.75 & 32.40 & 18.08 & 8.93 & 13.35 & 19.22 & 11.88 & 9.92 & 19.02 & 29.30 & 15.14 \\
\hline 2012 & 0.04 & 0.79 & 23.12 & 8.20 & 0.13 & 1.31 & 23.81 & 11.59 & 3.22 & 5.32 & 11.97 & 5.52 & 3.68 & 9.55 & 20.36 & 7.87 \\
\hline 2013 & 0.00 & 0.00 & 0.00 & 4.25 & 0.08 & 0.51 & 0.68 & 7.53 & 2.18 & 3.04 & 4.96 & 4.08 & 2.45 & 6.07 & 10.92 & 5.95 \\
\hline 2014 & 0.00 & 0.00 & 0.00 & 0.61 & 0.08 & 0.49 & 0.66 & 3.76 & 2.46 & 3.43 & 4.38 & 4.97 & 2.71 & 6.46 & 9.76 & 7.00 \\
\hline 2015 & 0.00 & 0.00 & 0.00 & 1.28 & 0.08 & 0.48 & 0.63 & 4.41 & 2.42 & 2.76 & 3.31 & 4.82 & 2.67 & 5.18 & 7.62 & 6.75 \\
\hline
\end{tabular}

Source: IMF staff calculations.

Note: The estimation shows joint capital shortfall below market-implied Tier 1 capital, with a gradual increase of the hurdle rate from 2013 onwards consistent with the Basel III proposal as of December 2010

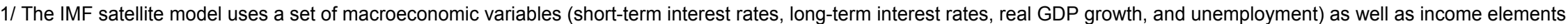
specific to each bank (operating profit, net interest income) to project potential losses generated by the CCA methodology.

2/ As an alternative, projected operating profit based on RAMSI model results is integrated in the CCA framework by adjusting implied bank assets, which increase potential losses via an option pricing approach. The treatment of losses from haircuts on holdings of sovereign and bank debt differs between both satellite model approaches. In the case of the former,

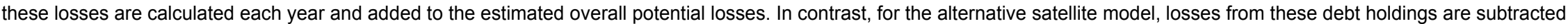
from the RAMSI-model projected operating profit each quarter. 


\section{Figure 15. Selected EU Countries: CDS Spreads}

(In basis points)

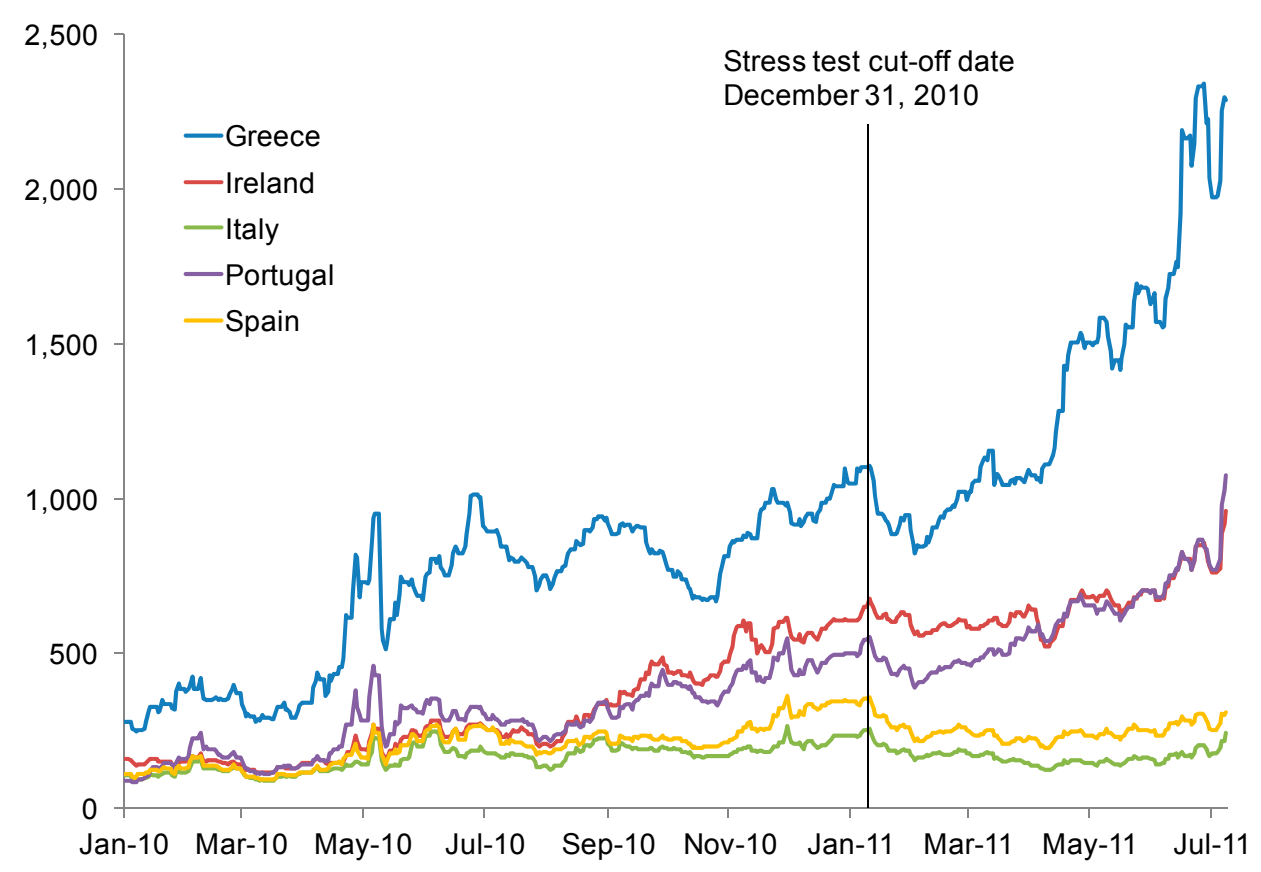

Source: Markit.

\section{Reconciliation of Bottom-Up with Top-Down Solvency Stress Test Results}

32. The RAMSI TD stress test results are broadly consistent with the aggregated BU findings. The trends for core Tier 1 and Tier 1 capital ratios, for the baseline and all three adverse scenarios, are broadly similar (Figures 16-18):

- $\quad$ The contrast between the RAMSI and BU results is partly driven by the differences in the baseline estimates. The RAMSI baseline is stronger than the BU baseline, largely due to the difference in the two approaches taken with regards to the growth of banks' RWAs: The BU tests assume higher asset growth than RAMSI, thus pushing the capital ratios down, with the effect becoming more marked in the latter years of the stress test horizon.

- $\quad$ Higher sovereign and bank debt haircuts account for the larger reduction in capital ratios in the RAMSI results, relative to the $B U$ ones. The impact is greater in the severe double dip and prolonged slow growth scenarios; the magnitude of these differences is reduced when the haircuts are excluded. 
33. Differences in the two sets of results are likely attributable to several factors:

- $\quad$ Sample banks. The BU tests are undertaken by the seven major U.K. banks; the RAMSI tests include five major banks (and Santander Group instead of Santander U.K.).

- $\quad$ Assumptions. Unavoidable differences in the stress test assumptions (Appendix I).

- $\quad$ Model design. The aggregate BU results are not derived from a specific model.

- $\quad$ Timeliness of exposure data. RAMSI assumes banks' sovereign debt exposures are unchanged from the 2010 CEBS stress test disclosures, whereas the BU tests use more up-to-date exposure data.

- $\quad$ Definition of and assumptions on capital and RWAs. RAMSI uses the Basel II definition of capital and RWAs, and assumes fixed risk weights for the baseline and stress projections. ${ }^{8}$ This would result in higher capital adequacy ratios compared to banks' BU results, which are based on the FSA's Interim Capital Regime definitions and assumes that changes in risk weights increase at the same rate as baseline nominal GDP growth throughout the period,

- Definition of exposures. RAMSI applies haircuts to banks' gross exposures, whereas banks implement the BU tests using their own risk management systems' exposure data that would have incorporated any hedged or netted positions.

- $\quad$ Trading book positions. Although both the RAMSI and BU stress tests apply haircuts to both banking and trading book positions, banks may have taken into account their marked-to-market losses as at end-2010 in applying the trading book haircuts.

\section{The Systemic CCA results provide support for the findings of the BU and}

RAMSI stress tests. The median shortfall amounts estimated by the Systemic CCA method suggest that markets are broadly comfortable that the current levels of capitalization of the major banks would be adequate to withstand the prescribed shocks. In all three stress testing approaches, the double-dip recession has proven to be the toughest shock scenario.

\footnotetext{
${ }^{8}$ Under RAMSI, banks are assumed to increase capital through retained earnings until they achieve challenging core Tier 1 capital ratio targets that are set using Basel III definitions and then translated back into Basel II terms.
} 
Figure 16. Weighted-Average Core Tier 1 Capital Ratios from the U.K. FSAP Update Bottom-Up and BoE RAMSI Top-Down Stress Tests, 2011-15

\author{
(In percentage points) 1/
}
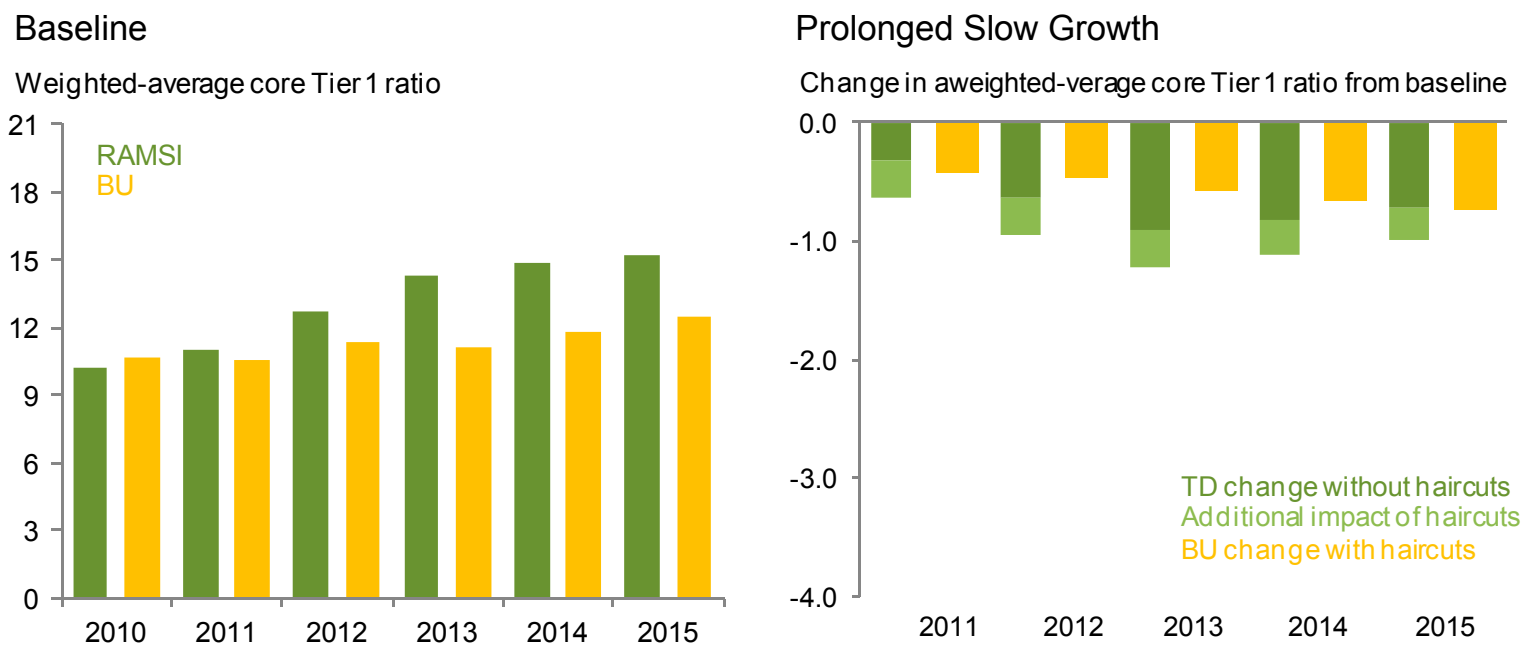

Double-Dip Mild

Change in weighted-average core Tier 1 ratio from baseline

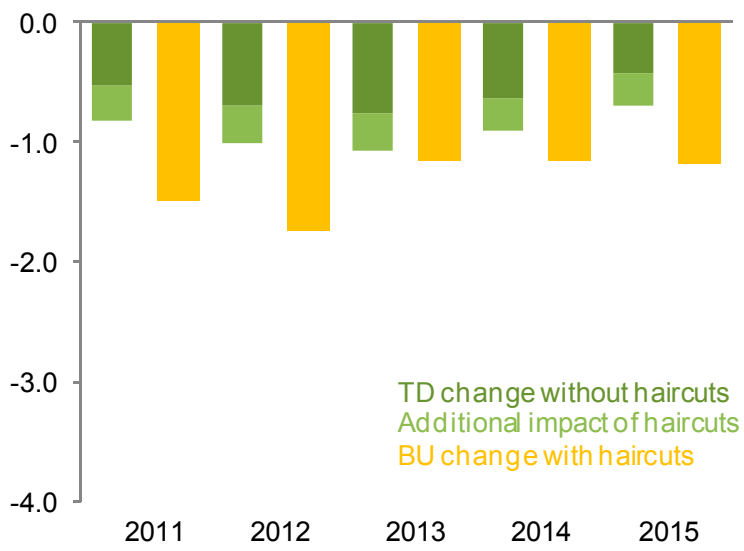

Double-Dip Severe

Change in weighted-average core Tier 1 ratio from baseline

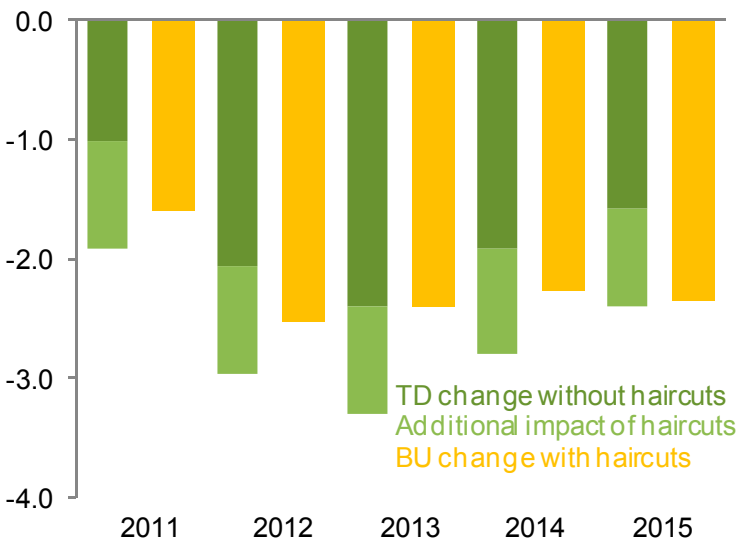

Sources: BoE; FSA; individual banks; and IMF staff calculations.

1/ The definitions of capital are as follows: For the BU exercise, the starting point is in line with FSA definitions as laid out in the FSA Handbook and the definition in the FSA's Interim Capital Regime; for the RAMSI, the Basel II-consistent definition of capital is used. 


\section{Figure 17. Tier 1 Capital Ratios from the U.K. FSAP Update Bottom-Up and BoE RAMSI Top-Down Stress Tests, 2011-15}

(In percentage points)

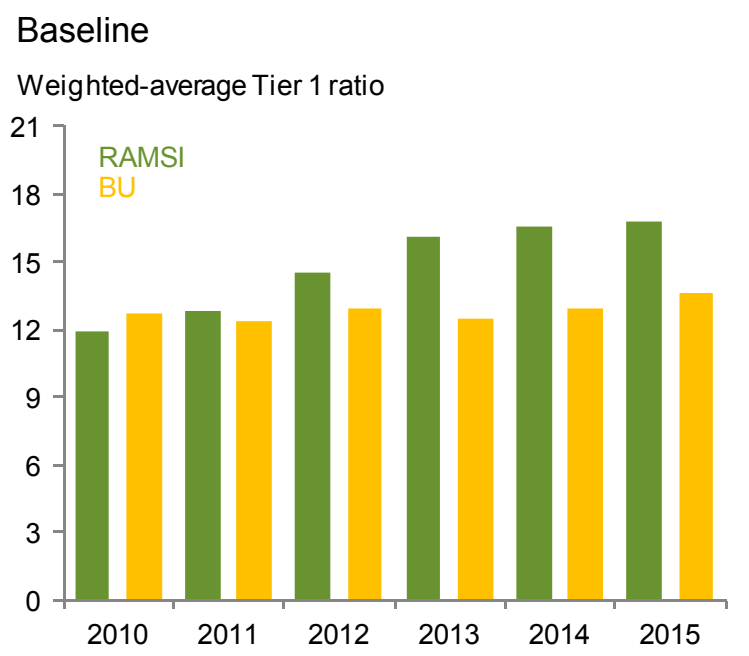

Double-Dip Mild

Change in weighted-average Tier 1 ratio from baseline

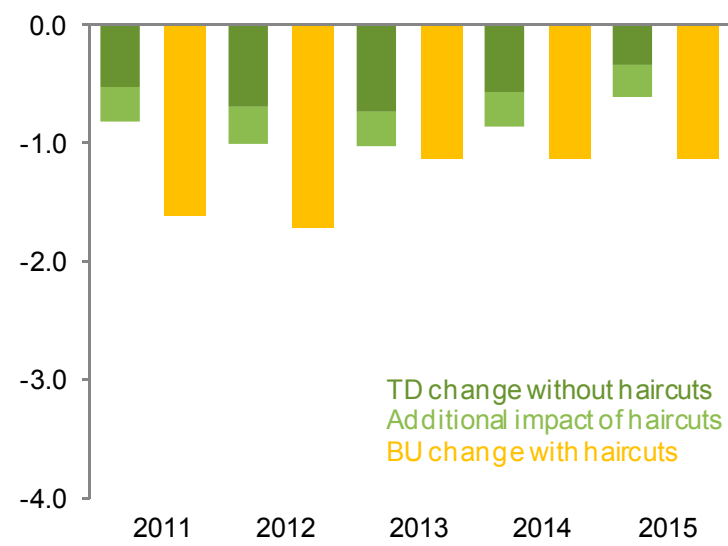

Prolonged Slow Growth

Change in weighted-average Tier 1 ratio from baseline

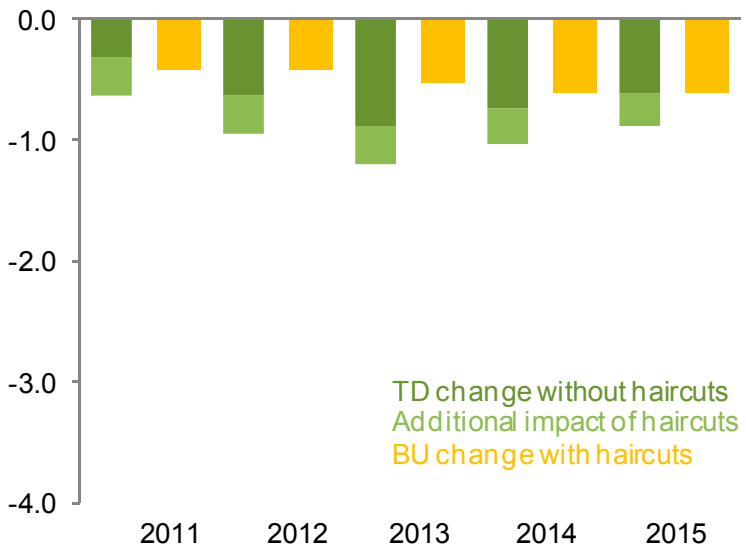

Double-Dip Severe

Change in weighted-average Tier 1 ratio from baseline

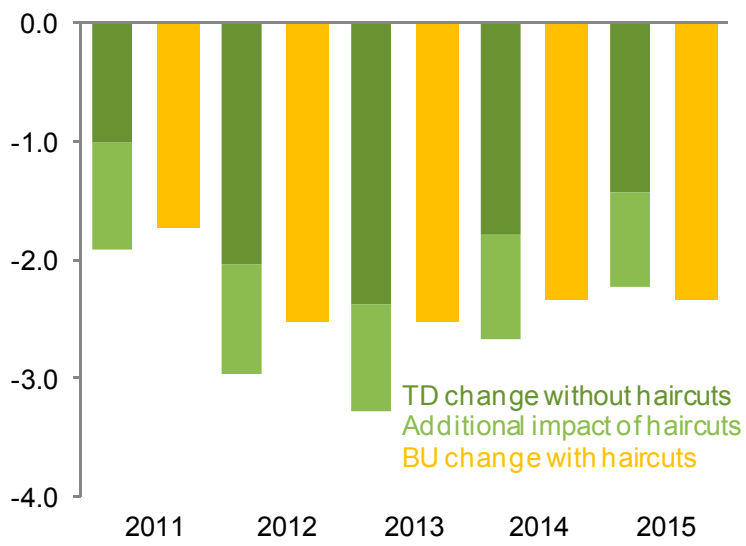

Sources: BoE; FSA; individual banks; and IMF staff calculations. 
Figure 18. Total Capital Ratios from the U.K. FSAP Update Bottom-Up and BoE RAMSI Top-Down Stress Tests, 2011-15

(In percentage points)

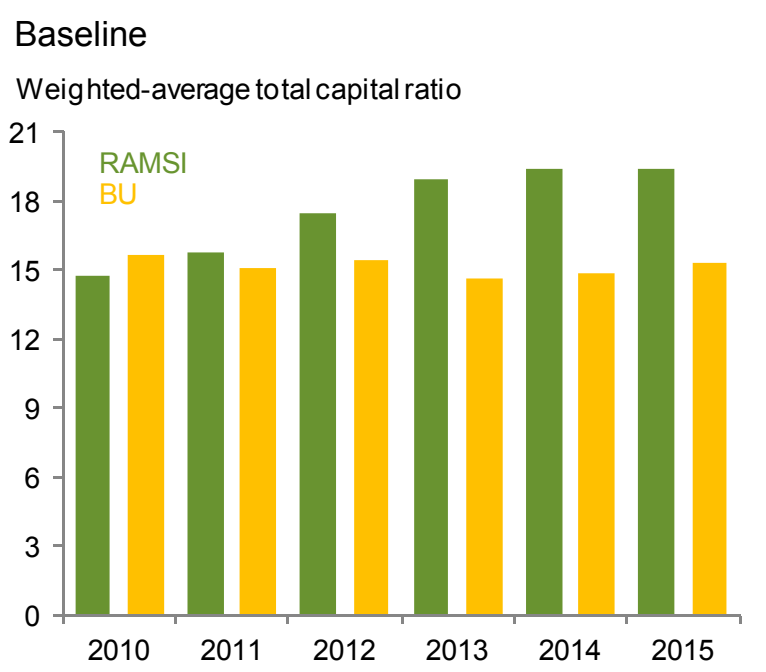

Double-Dip Mild

Change in weighted-average total capital ratio from baseline

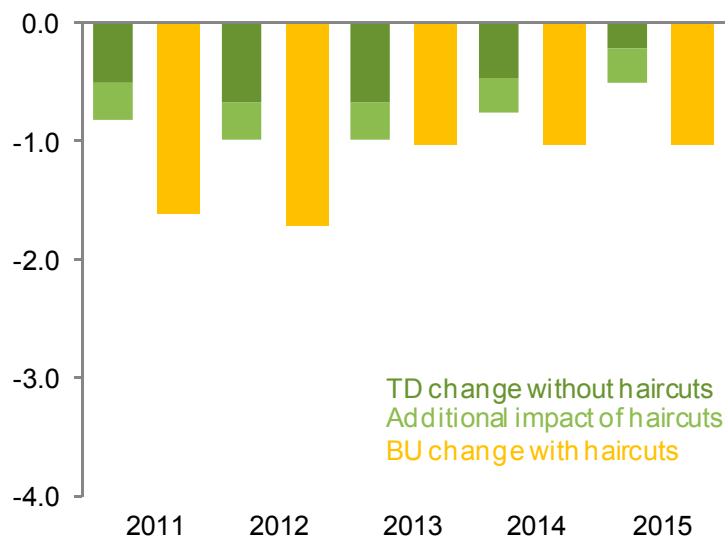

\section{Prolonged Slow Growth}

Change in weighted-average to tal capital ratio from baseline

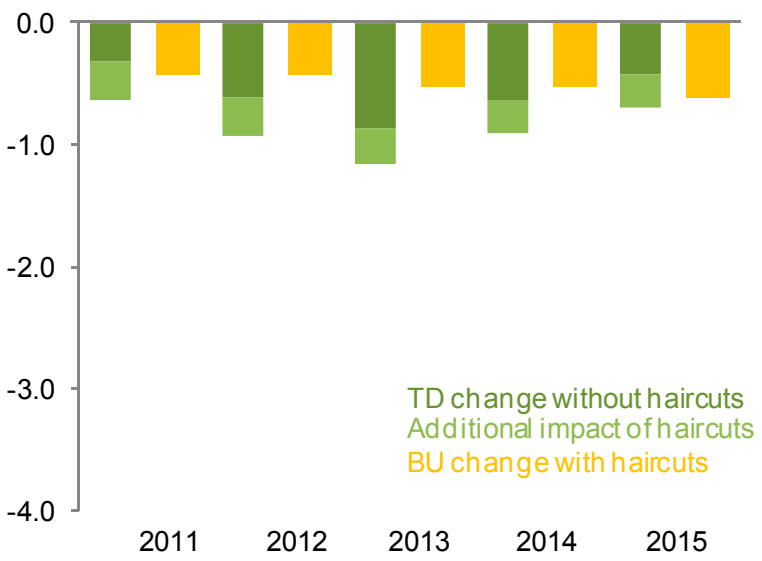

Double-Dip Severe

Change in weighted-average total capital ratio from baseline

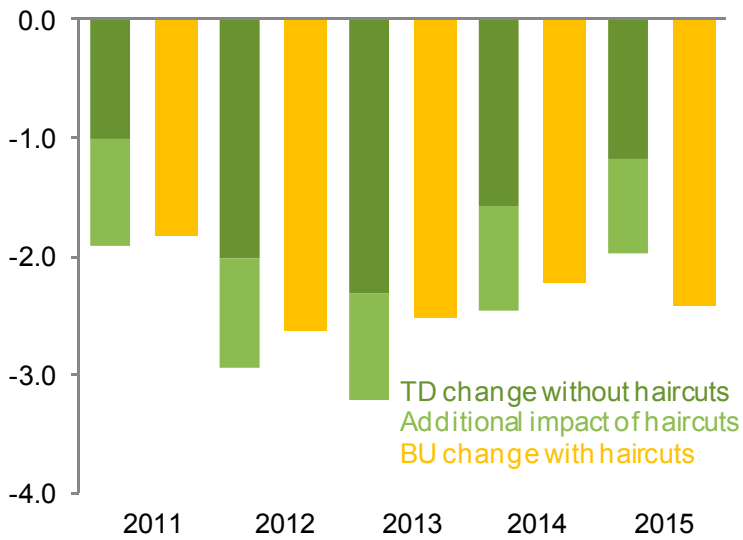

Sources: BoE; FSA; individual banks; and IMF staff calculations. 


\section{LIQUIDITY STRESS TESTS}

35. A suite of TD liquidity stress tests are carried out in order to assess the shortterm resilience of large financial institutions with respect to sudden, sizeable withdrawals of funding (liabilities). These liquidity tests focus on implied cash flow calculations and applied proxies for the proposed Basel III measures of liquidity risk, within the following parameters:

- $\quad$ The tests are conducted by the authorities using the spreadsheet-based tool provided by the FSAP team. The FSA's Liquidity Reporting Profile (LRP) data as at end-2010, for 16 large financial institutions consisting of the seven major banks (from the solvency stress test sample), building societies (including one cooperative bank) and five subsidiaries of foreign investment banks, are used in the exercise. The institutions are selected in collaboration with the U.K. authorities on the basis of supervisory remit.

- $\quad$ The liquidity stress tests are run separately from the solvency risk analysis.

- $\quad$ Outflow shocks are applied to a range of liabilities, including deposits, wholesale funding and intergroup funding, while haircuts to assets include investment and trading securities, derivatives and secured assets. Eligible securities could either be sold on secondary markets or used as collateral for normal access to central bank liquidity.

- $\quad$ The static nature of the tests and the assumption that all banks face escalating liquidity risk at the same time means that any estimated liquidity shortfall should be interpreted in terms of a general vulnerability to the particular assumptions rather than it being representative of an actual liquidity need.

- Where possible, the FSAP results are juxtaposed against the FSA's results for comparison purposes, to highlight the importance of the assumptions used (Appendix III).

36. The proposed liquidity tests comprise outflows of funding (liabilities) even as haircuts are being applied to assets on the balance sheet. Specifically:

- $\quad$ Two implied cash flow tests simulate a gradual outflow of funding over five consecutive days, and over a 30-day time horizon in keeping with a reverse stress test rationale. The analysis provides an assessment of the overall resilience of the system to a withdrawal of deposits and the run-off of wholesale funding. The aggregate outcome for European banks in the December 2010 quantitative impact study (QIS-6) is used as a proxy for cash flow assumptions. 
$>$ Two separate and additional specifications are also examined for each test: (i) customer deposits are assumed to be unaffected; ${ }^{9}$ (ii) intergroup funding is assumed to be available.

For simplicity of application, aggregate, rather than daily, flows data are used; the contractual nature of wholesale funding is ignored.

$>$ A bank is considered illiquid once deposits and wholesale funding are run down.

- $\quad$ The severity of the 30-day test exceeds the FSA's current supervisory requirements. The assumption of more than 40 percent outflows of deposits and wholesale funding for the 30-day test is considered a very severe one, worse than those experienced by Northern Rock during the crisis. ${ }^{10}$ This 30-day test is aimed at gauging the magnitude of shocks required to cause severe distress, using a reverse stress testing rationale, rather than at providing projections under scenarios. The objective is to reflect a series of assumptions that generate extremely severe liquidity risk scenarios. It does not take into account the following mitigating considerations:

Offsetting contractual capital inflows from maturing wholesale lending.

$>$ Possible central bank support via the BoE's discount window.

$>$ The likely positive effect on depositor confidence of having the Financial Services Compensation Scheme (FSCS) in place. ${ }^{11}$

$>$ A likely compensating outcome for the system as a whole, such as the reallocation of deposits within the banking sector when banks do not experience funding shocks simultaneously (and assuming that deposits largely remain in the banking system).

Additional analysis is conducted using the proposed Basel III liquidity risk measures. The LCR, which measures the sufficiency of the stock of high quality liquid assets to meet short-term liquidity needs under a specified acute stress scenario. The NSFR,

\footnotetext{
${ }^{9}$ The level of outflows of liabilities and the liquidity of assets under stress was set in accordance with empirical evidence, assumptions used in other FSAPs and upcoming regulatory changes.

${ }^{10}$ The implied cash flow analysis applies outflow assumptions to aggregate values of funding maturities of up to one month irrespective of callability.

${ }^{11}$ The scope of FSCS deposit insurance has been expanded from $£ 2000$ plus 90 percent of the next $£ 30,000$ to the maximum of $£ 85,000$ per customer, which covers around 80 percent of retail deposits in the system; speed of pay-out has also improved.
} 
which measures the amount of longer-term, stable sources of funding employed relative to the liquidity profiles of the assets funded and the potential for contingent calls on funding liquidity arising from off-balance sheet commitments and obligations, are derived to inform insights into the quality of liquid assets and the maturity profile and stability of funding. Given the tentative nature of these proposed measures, the FSAP team's interpretation of the proposed Basel III liquidity risk measures are applied, and referred to as quasi-measures. The FSAP's assumptions regarding contractual maturities and liquidity risk have been adopted on a best effort basis and reconciled with the FSA's own interpretation and assumptions, which differ somewhat. The results are juxtaposed against the FSA's for completeness:

- For the quasi-LCR, the minimum parameters for the outflow of stable and less stable deposits are selected for the FSAP tests. Other assumptions include: (i) the share of high quality liquid assets needed to satisfy margin calls (10 percent); (ii) the change in the market value of derivatives (20 percent); (iii) the share of assetbacked securities maturing within the next 30 days (10 percent); (iv) the share of undrawn but committed liabilities that are withdrawn (50 percent); and (v) the share of assets that is reinvested ( 80 percent). An LCR ratio of unity or greater suggests sufficient high-quality liquidity.

- For the quasi-NSFR, the FSAP's assumptions underpinning the definition of available sources of funding are very conservative and are defined in line with the final Basel III publication as of December 2010 (BCBS, 2010) and recent Fund staff analysis on systemic liquidity risk published in the April 2011 issue of the Global Financial Stability Report (IMF, 2011). Stable funding is defined by an NSFR ratio of unity or greater.

37. The results indicate that the banking system would be resilient against shortlived shocks to funding but may be vulnerable to more prolonged disruptions to funding access :

- $\quad$ Implied 5-day cash flow tests (Table 7). The banking system would largely be able to support a short-lived shock to cash flows.

○ The aggregate shortfall would equal 0.03 percent of assets included in the test.

- If deposits are assumed to remain stable, banks would generate sufficient cash inflows from asset sales to offset outflows.

- If intra-group lending is assumed to be readily available, the shortfall would be equivalent to around 0.03 percent of assets for the sample of 16 banks and 0.04 percent for the seven major banks. 
- Overall, the results suggest that retail deposits are a much more important source of funding for the banking system, and that intra-group funding does not play a big role for the foreign subsidiaries in the sample.

- Implied 30-day cash flow tests (Table 7). Despite the extreme severity of the test, the overall liquidity shortfall remains largely contained under more severe cash outflows over 30 days, where deposit outflows and run-offs of liabilities are doubled. ${ }^{12}$

- Although more banks would be affected - as would be expected - with an aggregate shortfall equal to under 6 percent of assets used in the liquidity calculations for the sample of 16 banks (an average shortfall of 0.4 percent of assets) and about 6.6 percent of assets under consideration for the seven major banks (an average shortfall of 1 percent of assets), significant increases in the liquidity shortfall remain concentrated in a very few institutions.

- Retail deposits remain the key source of funding for banks that survive the 30-day test.

- These results are reflective of the relative importance of the maturity gap (i.e., a high portion of short-term deposits and a focus on medium and long-term lending, which applies to the retail-focused commercial banks and building societies in the sample) as well as the share of wholesale funding (which is high for some of the larger banks).

- By comparison, the FSA's 30-day survival test shows that all seven major banks would have had sufficient liquidity to sustain the prescribed shocks, while four banks out of the total sample of 16 would have come up short.

Quasi-LCR test (Table 8). All 16 banks pass the FSAP's quasi-LCR test, indicating a sufficient degree of highly liquid assets to withstand short-lived shocks to cash flows. Under the FSA's assumptions, with numerous banks - accounting about 85 percent of assets in the sample of sixteen banks and about 93 percent of assets of the seven major banks - falling below unity, largely concentrated in the $0.55-0.75$ range.

\footnotetext{
${ }^{12}$ The stress testing framework does not use daily cash flows for wholesale funding maturities but aggregates funding maturities of up to one month irrespective of callability. It is assumed that a proportion of such wholesale funding, which is otherwise contractual in nature, is withdrawn under the 5-day and 30-day cash flow test. This simplified assumption may overstate actual outflows unless daily cash inflows and outflows are matched and equally distributed over one month.
} 
Table 7. U.K. FSAP Update Liquidity Stress Tests: 5- and 30-Day Implied Cash Flow Analysis

\begin{tabular}{|c|c|c|c|c|c|}
\hline & \multirow{2}{*}{$\begin{array}{l}\text { Number of } \\
\text { Banks below } \\
\text { Defined } \\
\text { Benchmark }\end{array}$} & \multicolumn{2}{|c|}{$\begin{array}{c}\text { Shortfall } \\
\text { (In percent of total sample assets } \\
\text { included in the liquidity tests) }\end{array}$} & \multirow{2}{*}{$\begin{array}{c}\text { Cumulative } \\
\text { Withdrawal of } \\
\text { Deposits } 1 / \\
\text { (In percent of total } \\
\text { deposits) }\end{array}$} & \multirow{2}{*}{$\begin{array}{c}\text { Cumulative Loss } \\
\text { of Wholesale } \\
\text { Funding } 1 / \\
\text { (In percent of total } \\
\text { wholesale funding) }\end{array}$} \\
\hline & & Total & $\begin{array}{c}\text { Average per Bank } \\
\text { in Shortfall }\end{array}$ & & \\
\hline & \multicolumn{5}{|c|}{ 5-Day Test } \\
\hline \multicolumn{6}{|l|}{ All firms (16) } \\
\hline Original assumptions & 1 & 0.03 & 0.03 & 18.0 & 25.5 \\
\hline Alternative 1: No withdrawal of retail deposits & 0 & 0.00 & 0.00 & 5.0 & 25.5 \\
\hline Alternative 2: Availability of intergroup funding & 1 & 0.03 & 0.03 & 18.0 & 25.5 \\
\hline \multicolumn{6}{|l|}{ Largest firms (7) } \\
\hline Original assumptions & 1 & 0.04 & 0.04 & 18.4 & 27.5 \\
\hline Alternative 1: No withdrawal of retail deposits & 0 & 0.00 & 0.00 & 4.9 & 27.5 \\
\hline Alternative 2: Availability of intergroup funding & 1 & 0.04 & 0.04 & 18.4 & 27.5 \\
\hline & \multicolumn{5}{|c|}{ 30-Day Test } \\
\hline \multicolumn{6}{|l|}{ All firms (16) } \\
\hline Original assumptions & 14 & 5.77 & 0.41 & 43.8 & 40.9 \\
\hline Alternative 1: No withdrawal of retail deposits & 4 & 0.41 & 0.10 & 15.2 & 40.9 \\
\hline Alternative 2: Availability of intergroup funding & 9 & 2.22 & 0.25 & 43.8 & 40.9 \\
\hline \multicolumn{6}{|l|}{ Largest firms (7) } \\
\hline Original assumptions & 7 & 6.64 & 0.95 & 44.6 & 41.5 \\
\hline Alternative 1: No withdrawal of retail deposits & 1 & 0.02 & 0.02 & 14.6 & 41.5 \\
\hline Alternative 2: Availability of intergroup funding & 5 & 2.81 & 0.56 & 44.6 & 41.5 \\
\hline
\end{tabular}

Sources: FSA; and IMF staff calculations.

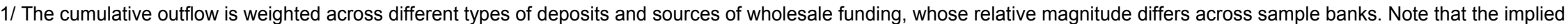
cash flow analysis applies outflow assumptions to aggregate values of funding maturities of up to one month irrespective of callability. The FSA does not complete tests that are directly comparable to these results. However, the survival day metric monitored by the FSA to assess vulnerabilities to wholesale funding is broadly similar to the 30 -day test. 


\section{Table 8. U.K. FSAP Update Liquidity Stress Tests: Quasi-Basel III and Maturity Mismatch Analysis}

(In percent of total sample assets included in the liquidity tests)

\begin{tabular}{|c|c|c|c|c|c|}
\hline \multirow[b]{3}{*}{ Ratio range } & \multicolumn{5}{|c|}{ Measure } \\
\hline & \multicolumn{5}{|c|}{ Quasi-Liquidity Coverage Ratio (LCR) } \\
\hline & $<0.25$ & $0.25-0.50$ & $0.50-0.75$ & $0.75-1.00$ & $>1.00$ \\
\hline & \multicolumn{5}{|c|}{ FSAP Assumptions } \\
\hline All firms (16) & - & - & - & - & 100.0 \\
\hline \multirow[t]{2}{*}{ Largest firms (7) } & - & - & - & - & 100.0 \\
\hline & \multicolumn{5}{|c|}{ FSA Assumptions } \\
\hline All firms (16) & - & 5.1 & 64.2 & 15.4 & 15.3 \\
\hline \multirow[t]{2}{*}{ Largest firms (7) } & - & - & 74.7 & 19.0 & 6.3 \\
\hline & \multicolumn{5}{|c|}{ Quasi-Net Stable Funding Ratio (NSFR) } \\
\hline \multirow[t]{2}{*}{ Ratio range } & $<0.25$ & $0.25-0.50$ & $0.50-0.75$ & $0.75-1.00$ & $>1.00$ \\
\hline & \multicolumn{5}{|c|}{ FSAP Assumptions } \\
\hline All firms (16) & 11.4 & 25.4 & 50.9 & 9.9 & 2.3 \\
\hline \multirow[t]{2}{*}{ Largest firms (7) } & - & 28.3 & 58.2 & 12.3 & 1.2 \\
\hline & \multicolumn{5}{|c|}{ FSA Assumptions } \\
\hline All firms (16) & - & 2.6 & - & 89.8 & 7.6 \\
\hline \multirow[t]{2}{*}{ Largest firms (7) } & - & - & - & 100.0 & - \\
\hline & \multicolumn{5}{|c|}{ Maturity Mismatch 1/ } \\
\hline Maturity tenor & $\begin{array}{l}\text { less than } 1 \\
\text { month }\end{array}$ & $\begin{array}{l}\text { within 1-3 } \\
\text { months }\end{array}$ & $\begin{array}{l}\text { within 3-6 } \\
\text { months }\end{array}$ & $\begin{array}{c}\text { between 6-12 } \\
\text { months }\end{array}$ & $\begin{array}{l}\text { after } 12 \\
\text { months }\end{array}$ \\
\hline All firms (16) & 11.6 & 29.1 & 22.3 & 68.9 & 89.2 \\
\hline Largest firms (7) & - & 23.9 & 16.8 & 70.5 & 92.7 \\
\hline
\end{tabular}

Sources: FSA; and IMF staff calculations.

1/ The maturity mismatch of each bank is calculated as the difference of the value of assets and liabilities in each of six "maturity buckets" determined by their tenor and callability, i.e., (i) on demand, (ii) up to one month, (iii) between one month and three months, (iv) between three months and six months, (v) between six months and twelve months, and (v) greater than 12 months. For a given "maturity bucket", the total assets of all banks that exhibit mismatch are added and divided by the total assets of all banks in the sample. The differences between the FSAP and FSA assumptions lie largely in the interpretation of the proposed Basel III measures. 
Quasi-NSFR (Table 8). In the FSAP test, the indicator falls below unity for banks accounting for more than 95 percent of assets in each sample. In both samples, banks accounting for some 50-60 percent of assets have NSFRs falling in the 0.50-0.75 range, suggesting insufficiently stable sources of funding in the system. The concentration is different for the FSA's corresponding test, with banks accounting for around 90 percent of assets in the sample of 16 banks and 100 percent of all seven major banks clustered in the $0.75-1.00$ range.

Maturity mismatch. The maturity mismatch in banks' liquidity profiles support the quasi-NSFR findings. In the 6-12 months maturity bucket, assets that are mismatched amount to about 70 percent of the total assets of all banks in the sample, and the proportion goes up to around 90 percent in the 12-plus months maturity bucket. For some banks, this vulnerability would be amplified by concentrations of sizeable reliance on wholesale funding.

38. The overall results suggest that the banking system would be able to withstand moderately severe cash flow shocks, without the need for access to central bank liquidity. However, intensification of market stresses, amplified by the considerable interconnectedness of the United Kingdom to the global financial system is an important concern. Sustained disruptions to wholesale funding markets - possibly due to the realization of sovereign risks in the EU and potentially exacerbated by market uncertainty about the outcome of current deliberations by the ICB - affecting repo markets and counterparty risk assessments, coupled with a persistent decline in asset values, could expose vulnerabilities if individual banks lose access to their funding sources.

\section{Summary ANd Policy ImPlications}

39. The U.K. banking system appears to be adequately capitalized against adverse shocks and banks are well-placed to meet the Basel III solvency requirements. It is evident that the significant recapitalization of the U.K. banking sector, in tandem with the derisking of balance sheets, has been critical in boosting the solvency of the system. Both the BU stress test results by banks as well as the cross-validation TD tests by the BoE indicate that the capital adequacy of the aggregate banking system as at end-2010 would comfortably pass the Basel III (and FSA Interim Capital Regime) hurdle rates under the defined shock scenarios; the capital adequacy of individual banks varies, but all would be able to absorb the shocks clear the hurdle rates as well. The FSAP's own TD tests suggest that markets also consider banks to be sufficiently capitalized against the prescribed shocks.

40. While banks have continued to improve their funding profiles, significant work is still required to reduce liquidity risk in the system. The liquidity stress tests, comprising reverse stress tests and proxies for the proposed liquidity measures under Basel III, assess the resilience of the banking system to a loss in funding and market access (including the closure of long-term and short-term funding markets and higher funding costs), as well as haircuts in 
the realization of liquid assets. The results indicate that the banking system would have sufficient liquid assets to withstand short-lived cash flow stresses (without taking into account access to central bank liquidity), but that significant maturity mismatch exist in banks' liquidity profiles at the six-month maturity mark and beyond.

\section{It is imperative that complacency does not set in and that the restructuring and} de-risking of banks' balance sheets continue. The asset quality of institutions may be at risk in the event of a severe double-dip recession or if the recovery of the U.K. economy is drawn out, especially if lender forbearance is also masking the true extent of risks in residential and commercial real estate lending. Any significant escalation in stresses under these scenarios resulting in the realization of extreme tail risks could and potentially push joint potential capital losses below the distress barrier, resulting in a capital shortfall relative to the Basel III (and FSA) hurdle rates. The deterioration in the outlook for vulnerable EU sovereigns since the cut-off date for the stress tests represents a potentially significant concern for solvency and liquidity risks in the U.K. banking system, while the as yet unknown outcome of current regulatory deliberations on the banking sector adds to the uncertainty. Banks' funding sources are not yet sufficiently stable, and they remain vulnerable to sustained disruptions to funding markets.

\section{Overall, the stress test results confirm the supervisory focus to require banks to} build up capital and liquidity buffers both in terms of institution-specific requirements as well as industry-wide standards. U.K. banks are subject to the Basel III capital requirements, including trading book capital charges, according to the agreed gradual phasein schedule, in order to balance the potential adverse implications on lending, while the core Tier 1 and Tier 1 capital requirements of the FSA's interim supervisory framework were implemented during the crisis in anticipation of the Basel III proposals. The authorities have also decided to implement liquidity requirements ahead of the phase-in schedule agreed internationally. While the solvency and liquidity regulations are more stringent than in other major jurisdictions presently, they appropriately reflect the authorities' response to the specific structure and vulnerabilities of the U.K. financial system presently and the lessons learned from the crisis. 


\section{APPENDIX I. KeY ASSUMPTIONS APPLIED IN THE U.K. FSAP UPDATE SOLVENCY STRESS TESTS RELATIVE TO THE EUROPEAN BANKING AUTHORITY (EBA) AND FSA SUPERVISORY STRESS TESTS}

\begin{tabular}{|c|c|c|c|c|c|c|}
\hline \multirow[t]{3}{*}{ Domain } & \multirow[t]{3}{*}{ Element } & \multicolumn{5}{|c|}{ Assumptions Made in Stress Tests } \\
\hline & & \multicolumn{3}{|c|}{ FSAP Update } & EBA & FSA 1/ \\
\hline & & $\begin{array}{l}\text { Bottom-Up by } \\
\text { Banks }\end{array}$ & $\begin{array}{l}\text { Top-Down by } \\
\text { Authorities }\end{array}$ & $\begin{array}{l}\text { Top-Down by } \\
\text { FSAP Team }\end{array}$ & $\begin{array}{c}\text { Bottom-Up by U.K. } \\
\text { Banks }\end{array}$ & $\begin{array}{c}\text { Bottom-Up by U.K. } \\
\text { Banks }\end{array}$ \\
\hline Institutions & Banks & $\begin{array}{l}\text { - Seven SIFIs } \\
\text { (Barclays, HSBC, } \\
\text { LBG, RBS, SCB, } \\
\text { Santander U.K., } \\
\text { Nationwide). }\end{array}$ & $\begin{array}{l}\text { Five SIFIs } \\
\text { (Barclays, HSBC, } \\
\text { LBG, RBS, } \\
\text { Santander U.K.). }\end{array}$ & $\begin{array}{l}\text { Seven SIFIs } \\
\text { (Barclays, HSBC, } \\
\text { LBG, RBS, SCB, } \\
\text { Santander U.K., } \\
\text { Nationwide). }\end{array}$ & $\begin{array}{l}\text { - Four SIFIs } \\
\text { (Barclays, HSBC, } \\
\text { LBG, RBS). }\end{array}$ & $\begin{array}{l}\text { - Major U.K. banking } \\
\text { groups. }\end{array}$ \\
\hline Market share & $\begin{array}{l}\text { Assets } \\
\text { Lending }\end{array}$ & $\begin{array}{l}\text { - } 71 \text { percent of } \\
\text { banking system } \\
\text { assets. } \\
\text { - } 89 \text { percent of total } \\
\text { lending. }\end{array}$ & $\begin{array}{l}\text { - } 65 \text { percent of } \\
\text { banking system } \\
\text { assets. } \\
\text { - } 79 \text { percent of total } \\
\text { lending. }\end{array}$ & $\begin{array}{l}\text { - } 71 \text { percent of } \\
\text { banking system } \\
\text { assets. } \\
\text { - } 89 \text { percent of total } \\
\text { lending. }\end{array}$ & $\begin{array}{l}\text { - } 62 \text { percent of } \\
\text { banking system } \\
\text { assets. } \\
\text { - } 72 \text { percent of total } \\
\text { lending. }\end{array}$ & $\begin{array}{l}\text { - } 72 \text { percent of } \\
\text { banking system } \\
\text { assets. } \\
\text { - } 90 \text { percent of total } \\
\text { lending. }\end{array}$ \\
\hline Data & Source & - Bank's own data. & $\begin{array}{l}\text { - Supervisory data. } \\
\text { - Publicly available } \\
\text { data. }\end{array}$ & $\begin{array}{l}\text { - Supervisory data. } \\
\text { - Publicly available } \\
\text { data. }\end{array}$ & - Bank's own data. & - Bank's own data. \\
\hline Methodology & Model & $\begin{array}{l}\text { - Banks' internal } \\
\text { models. }\end{array}$ & - BoE RAMSI. & - Systemic CCA. & $\begin{array}{l}\text { - } \begin{array}{l}\text { Banks' internal } \\
\text { models. }\end{array} \\
\text { model }\end{array}$ & $\begin{array}{l}\text { - Banks' internal } \\
\text { models. }\end{array}$ \\
\hline $\begin{array}{l}\text { Scope of } \\
\text { consolidation }\end{array}$ & & \multicolumn{5}{|c|}{ - Consolidated banking group. } \\
\hline Stress test horizon & Years & \multicolumn{3}{|l|}{ - 2011-2015. } & - 2011-2012. & $\begin{array}{l}\text { - Up to } 5 \text { years with } \\
\text { first year being } \\
2010 \text { or } 2011 \\
\text { depending on the } \\
\text { bank. }\end{array}$ \\
\hline Scenario & Macro-financial & \multicolumn{3}{|c|}{$\begin{array}{l}\text { - Shocks are conditional on macro scenarios (GDP, inflation, } \\
\text { interest rates, unemployment, U.K. commercial and residential } \\
\text { property and equity prices). } \\
\text { GDP shock scenarios: } \\
\text { - One standard deviation from the WEO baseline. }\end{array}$} & $\begin{array}{l}\text { Shocks are } \\
\text { conditional on } \\
\text { macro-financial } \\
\text { scenarios (GDP, } \\
\text { inflation, interest } \\
\text { rates, }\end{array}$ & $\begin{array}{l}\text { Shocks are } \\
\text { conditional on } \\
\text { macro-financial } \\
\text { scenarios (GDP, } \\
\text { U.K. housing and } \\
\text { commercial }\end{array}$ \\
\hline
\end{tabular}




\begin{tabular}{|c|c|c|c|c|c|c|}
\hline \multirow[t]{3}{*}{ Domain } & \multirow[t]{3}{*}{ Element } & \multicolumn{5}{|c|}{ Assumptions Made in Stress Tests } \\
\hline & & \multicolumn{3}{|c|}{ FSAP Update } & \multirow{2}{*}{\begin{tabular}{|c|} 
EBA \\
$\begin{array}{c}\text { Bottom-Up by U.K. } \\
\text { Banks }\end{array}$
\end{tabular}} & \multirow{2}{*}{$\begin{array}{c}\text { FSA 1/ } \\
\text { Bottom-Up by U.K. } \\
\text { Banks }\end{array}$} \\
\hline & & $\begin{array}{l}\text { Bottom-Up by } \\
\text { Banks }\end{array}$ & $\begin{array}{l}\text { Top-Down by } \\
\text { Authorities }\end{array}$ & $\begin{array}{l}\text { Top-Down by } \\
\text { FSAP Team }\end{array}$ & & \\
\hline & & \multicolumn{3}{|c|}{$\begin{array}{l}\text { - Two standard deviations from the WEO baseline. } \\
\text { - Prolonged slow growth (with over } 7 \text { percent cumulative } \\
\text { deviation from WEO baseline). }\end{array}$} & $\begin{array}{l}\text { unemployment, } \\
\text { U.K. commercial } \\
\text { and residential } \\
\text { property prices, } \\
\text { nominal U.S. dollar } \\
\text { exchange rate). } \\
\text { GDP shock scenario: } \\
\text { 1.3-1.4 standard } \\
\text { deviations from the } \\
\text { Autumn } 2010 \\
\text { European } \\
\text { Commission } \\
\text { baseline. }\end{array}$ & $\begin{array}{l}\text { property and equity } \\
\text { prices, } \\
\text { unemployment, key } \\
\text { economic variables } \\
\text { for America, } \\
\text { Europe and Asia). } \\
\text { GDP shock scenario: } \\
\text { - Two standard } \\
\text { deviations from } \\
\text { Consensus } \\
\text { forecasts. }\end{array}$ \\
\hline \multirow[t]{2}{*}{ Risk factors } & Credit losses & $\begin{array}{l}\text { - Credit losses are } \\
\text { based on banks' } \\
\text { satellite models. }\end{array}$ & \multicolumn{2}{|c|}{$\begin{array}{l}\text { - Credit losses are based on satellite } \\
\text { model using various macro and bank- } \\
\text { specific variables. }\end{array}$} & $\begin{array}{l}\text { - Impairment flows } \\
\text { are estimated both } \\
\text { on defaulted and } \\
\text { non-defaulted } \\
\text { assets by applying } \\
\text { expected loss } \\
\text { given default } \\
\text { (LGD) rates. } \\
\text { - New defaulted } \\
\text { assets are } \\
\text { estimated by } \\
\text { applying the } \\
\text { probability of } \\
\text { default (PD) on the } \\
\text { initial exposure at } \\
\text { default (EAD). }\end{array}$ & $\begin{array}{l}\text { Impairments based } \\
\text { on link to macro- } \\
\text { economic variables } \\
\text { as determined by } \\
\text { each bank. }\end{array}$ \\
\hline & Profitability & $\begin{array}{l}\text { - Profit (interest } \\
\text { income, interest }\end{array}$ & \multicolumn{2}{|c|}{$\begin{array}{l}\text { - Profit and trading income are based on } \\
\text { satellite models using various macro and }\end{array}$} & $\begin{array}{l}\text { - The P\&L base is } \\
\text { determined in a }\end{array}$ & $\begin{array}{l}\text { - Profit (interest } \\
\text { income, interest }\end{array}$ \\
\hline
\end{tabular}

CInternational Monetary Fund. Not for Redistribution 


\begin{tabular}{|c|c|c|c|c|c|c|}
\hline \multirow[t]{3}{*}{ Domain } & \multirow[t]{3}{*}{ Element } & \multicolumn{5}{|c|}{ Assumptions Made in Stress Tests } \\
\hline & & \multicolumn{3}{|c|}{ FSAP Update } & \multirow{2}{*}{\begin{tabular}{|c|} 
EBA \\
$\begin{array}{c}\text { Bottom-Up by U.K. } \\
\text { Banks }\end{array}$ \\
\end{tabular}} & \multirow{2}{*}{$\begin{array}{c}\text { FSA 1/ } \\
\text { Bottom-Up by U.K. } \\
\text { Banks }\end{array}$} \\
\hline & & $\begin{array}{c}\text { Bottom-Up by } \\
\text { Banks }\end{array}$ & $\begin{array}{c}\text { Top-Down by } \\
\text { Authorities }\end{array}$ & $\begin{array}{l}\text { Top-Down by } \\
\text { FSAP Team }\end{array}$ & & \\
\hline & & $\begin{array}{l}\text { expense, net fee } \\
\text { and commission } \\
\text { income, operation } \\
\text { expenses) should } \\
\text { be based on } \\
\text { banks' satellite } \\
\text { models or expert } \\
\text { judgment. } \\
\text { - Trading income is } \\
\text { derived from } \\
\text { banks' satellite } \\
\text { models or } \\
\text { statistical } \\
\text { matching with } \\
\text { GDP growth } \\
\text { (conditional on } \\
\text { changes in } \\
\text { trading assets). }\end{array}$ & \multicolumn{2}{|c|}{ bank-specific variables. } & $\begin{array}{l}\text { conservative way } \\
\text { and directly reflects } \\
\text { the translation of } \\
\text { macro-economic } \\
\text { scenarios, avoiding } \\
\text { non-recurrent } \\
\text { income and } \\
\text { expenses. }\end{array}$ & $\begin{array}{l}\text { expense, net fee } \\
\text { and commission } \\
\text { income, operation } \\
\text { expenses) based } \\
\text { on banks' own } \\
\text { models or expert } \\
\text { judgment. } \\
\text { - Trading income is } \\
\text { derived from } \\
\text { banks' own models } \\
\text { taking account of } \\
\text { GDP growth } \\
\text { (conditional on } \\
\text { changes in trading } \\
\text { assets). }\end{array}$ \\
\hline & Funding costs & $\begin{array}{l}\text { - Funding costs are } \\
\text { derived from } \\
\text { either satellite } \\
\text { models for } \\
\text { interest expense } \\
\text { or an IMF- } \\
\text { provided } \\
\text { methodology. } \\
\text { Changes in costs } \\
\text { due to solvency } \\
\text { conditions cannot } \\
\text { be smaller than } \\
\text { those generated. }\end{array}$ & \multicolumn{2}{|c|}{$\begin{array}{l}\text { - Funding costs are based on satellite } \\
\text { model using various macro and bank- } \\
\text { specific variables. }\end{array}$} & $\begin{array}{l}\text { - Funding costs are } \\
\text { driven by the } \\
\text { increase in short } \\
\text { and long term } \\
\text { interest rates, the } \\
\text { rise in banks' credit } \\
\text { spreads; the drop } \\
\text { in the value of the } \\
\text { sovereign assets } \\
\text { used as collateral; } \\
\text { deposits. } \\
\text { Maturing liabilities } \\
\text { are expected to be } \\
\text { substituted with } \\
\text { liabilities having }\end{array}$ & $\begin{array}{l}\text { - Reflects bank's } \\
\text { specific funding } \\
\text { profile and impacts } \\
\text { from changes in } \\
\text { interest rates as } \\
\text { specified in stress, } \\
\text { funding } \\
\text { implications of } \\
\text { balance sheet } \\
\text { evolution including } \\
\text { liquidity costs, and } \\
\text { any increase in } \\
\text { funding costs } \\
\text { stemming from } \\
\text { increase in bank's }\end{array}$ \\
\hline
\end{tabular}

CInternational Monetary Fund. Not for Redistribution 


\begin{tabular}{|c|c|c|c|c|c|c|}
\hline \multirow[t]{3}{*}{ Domain } & \multirow[t]{3}{*}{ Element } & \multicolumn{5}{|c|}{ Assumptions Made in Stress Tests } \\
\hline & & \multicolumn{3}{|c|}{ FSAP Update } & \multirow{2}{*}{\begin{tabular}{|c|} 
EBA \\
$\begin{array}{c}\text { Bottom-Up by U.K. } \\
\text { Banks }\end{array}$ \\
\end{tabular}} & \multirow{2}{*}{$\begin{array}{c}\text { FSA 1/ } \\
\text { Bottom-Up by U.K. } \\
\text { Banks }\end{array}$} \\
\hline & & $\begin{array}{c}\text { Bottom-Up by } \\
\text { Banks }\end{array}$ & $\begin{array}{l}\text { Top-Down by } \\
\text { Authorities }\end{array}$ & $\begin{array}{l}\text { Top-Down by } \\
\text { FSAP Team }\end{array}$ & & \\
\hline & & & & & $\begin{array}{l}\text { the same residual } \\
\text { maturity. }\end{array}$ & credit spreads. \\
\hline & $\begin{array}{l}\text { Fixed income } \\
\text { holdings }\end{array}$ & $\begin{array}{l}\text { - Haircuts (using an } \\
\text { IMF-provided } \\
\text { methodology) are } \\
\text { applied to } \\
\text { holdings of both } \\
\text { sovereign and } \\
\text { bank debt, in both } \\
\text { the trading and } \\
\text { banking books. } \\
\text { - Haircuts are } \\
\text { applied only to } \\
\text { non-AAA rated } \\
\text { issuers. } \\
\text { - Cash at central } \\
\text { banks as well as } \\
\text { repos or asset } \\
\text { swaps where } \\
\text { there is no } \\
\text { economic interest } \\
\text { in the security are } \\
\text { excluded. }\end{array}$ & $\begin{array}{l}\text { - Haircuts (using } \\
\text { methodology) a } \\
\text { sovereign debt } \\
\text { available data- } \\
\text { bank debt (base } \\
\text { banking statistic } \\
\text { and banking bo }\end{array}$ & $\begin{array}{l}\text {-provided } \\
\text { ied to holdings of } \\
\text { on latest } \\
2010 \text { ) and to } \\
\text { IS consolidated } \\
\text { oth the trading }\end{array}$ & $\begin{array}{l}\text { Haircuts are } \\
\text { applied to holdings } \\
\text { of sovereign debt } \\
\text { in the trading book. }\end{array}$ & $\begin{array}{l}\text { Application of } \\
\text { haircuts to fixed } \\
\text { income positions in } \\
\text { the trading and } \\
\text { banking books } \\
\text { based on banks' } \\
\text { own assumptions. }\end{array}$ \\
\hline & Exchange rate & $\begin{array}{l}\text { - Impact of } \\
\text { valuation changes } \\
\text { of net open } \\
\text { positions as a } \\
\text { result of shocks to } \\
\text { the U.S, dollar, } \\
\text { the euro and the } \\
\text { Japanese yen. } \\
\text { - Shock should be }\end{array}$ & - N.A. & & $\begin{array}{l}\text { - Impact must be in } \\
\text { line with the } \\
\text { expected evolution } \\
\text { of exchange rates } \\
\text { in the } \\
\text { macroeconomic } \\
\text { scenario. }\end{array}$ & $\begin{array}{l}\text { Impact as } \\
\text { assessed by each } \\
\text { bank in line with } \\
\text { their assumptions } \\
\text { about how } \\
\text { exchange rates will } \\
\text { evolve under the } \\
\text { designated } \\
\text { macroeconomic }\end{array}$ \\
\hline
\end{tabular}

CInternational Monetary Fund. Not for Redistribution 


\begin{tabular}{|c|c|c|c|c|c|c|}
\hline \multirow[t]{3}{*}{ Domain } & \multirow[t]{3}{*}{ Element } & \multicolumn{5}{|c|}{ Assumptions Made in Stress Tests } \\
\hline & & \multicolumn{3}{|c|}{ FSAP Update } & \multirow{2}{*}{\begin{tabular}{|c|} 
EBA \\
$\begin{array}{c}\text { Bottom-Up by U.K. } \\
\text { Banks }\end{array}$ \\
\end{tabular}} & \multirow{2}{*}{$\begin{array}{c}\text { FSA 1/ } \\
\text { Bottom-Up by U.K. } \\
\text { Banks }\end{array}$} \\
\hline & & $\begin{array}{c}\text { Bottom-Up by } \\
\text { Banks }\end{array}$ & $\begin{array}{l}\text { Top-Down by } \\
\text { Authorities }\end{array}$ & $\begin{array}{l}\text { Top-Down by } \\
\text { FSAP Team }\end{array}$ & & \\
\hline & & $\begin{array}{l}\text { twice the standard } \\
\text { deviation of the } \\
\text { respective FX } \\
\text { volatility during } \\
2010 \text { and impact } \\
\text { the trading book } \\
\text { in } 2011 \text { and } 2012 \\
\text { only. }\end{array}$ & & & & scenario. \\
\hline & Taxes & $\begin{array}{l}\text { A rate of } 25 \\
\text { percent in the } \\
\text { case of positive } \\
\text { profits, zero } \\
\text { otherwise. }\end{array}$ & $\begin{array}{l}\text { - Each bank's } \\
\text { tax/profit ratio set } \\
\text { to historical } \\
\text { averages unless } \\
\text { profits are } \\
\text { negative. Banks } \\
\text { not currently } \\
\text { paying tax } \\
\text { gradually increase } \\
\text { their ratio from } \\
\text { zero. }\end{array}$ & - N.A. & $\begin{array}{l}\text { - The tax regime as } \\
\text { at December } 2010 . \\
\text { - Deferred tax } \\
\text { credits may be } \\
\text { recognized. }\end{array}$ & $\begin{array}{l}\text { Banks provide tax } \\
\text { rate for each year } \\
\text { of the stress in } \\
\text { which they forecast } \\
\text { profits and their } \\
\text { assumptions about } \\
\text { creation of deferred } \\
\text { tax assets in loss } \\
\text { making years. }\end{array}$ \\
\hline Risk measurement & PDs and LGDs & $\begin{array}{l}\text { - Assumed to be } \\
\text { "through the } \\
\text { cycle." }\end{array}$ & - Point in time. & & & $\begin{array}{l}\text { - Through the cycle } \\
\text { or point in time } \\
\text { depending on } \\
\text { banks' own } \\
\text { approaches to risk } \\
\text { measurement. }\end{array}$ \\
\hline $\begin{array}{l}\text { Behavioral } \\
\text { adjustments }\end{array}$ & $\begin{array}{l}\text { Balance sheet } \\
\text { growth }\end{array}$ & $\begin{array}{l}\text { - Constant balance } \\
\text { sheet (growing in } \\
\text { line with nominal } \\
\text { GDP). } \\
\text { - Banks affected by } \\
\text { stress reduce } \\
\text { asset growth }\end{array}$ & $\begin{array}{l}\text { - Each bank holds } \\
\text { assets flat unless } \\
\text { and until its } \\
\text { capital ratio target } \\
\text { is met. }\end{array}$ & $\begin{array}{l}\text { - Endogenous to } \\
\text { market } \\
\text { expectations } \\
\text { implied by equity } \\
\text { cash and } \\
\text { derivative prices. }\end{array}$ & \begin{tabular}{|l} 
- Static balance \\
sheet (zero growth \\
and constant \\
business mix).
\end{tabular} & $\begin{array}{l}\text { - Dynamic balance } \\
\text { sheet based on } \\
\text { banks' } \\
\text { assumptions about } \\
\text { adjustments to } \\
\text { their base case } \\
\text { forecasts. }\end{array}$ \\
\hline
\end{tabular}

CInternational Monetary Fund. Not for Redistribution 


\begin{tabular}{|c|c|c|c|c|c|c|}
\hline \multirow[t]{3}{*}{ Domain } & \multirow[t]{3}{*}{ Element } & \multicolumn{5}{|c|}{ Assumptions Made in Stress Tests } \\
\hline & & \multicolumn{3}{|c|}{ FSAP Update } & \multirow{2}{*}{$\begin{array}{c}\text { EBA } \\
\text { Bottom-Up by U.K. } \\
\text { Banks }\end{array}$} & \multirow{2}{*}{$\begin{array}{c}\text { FSA 1/ } \\
\text { Bottom-Up by U.K. } \\
\text { Banks }\end{array}$} \\
\hline & & $\begin{array}{c}\text { Bottom-Up by } \\
\text { Banks }\end{array}$ & $\begin{array}{l}\text { Top-Down by } \\
\text { Authorities }\end{array}$ & $\begin{array}{l}\text { Top-Down by } \\
\text { FSAP Team }\end{array}$ & & \\
\hline & & $\begin{array}{l}\text { through } \\
\text { deleveraging or } \\
\text { other means. }\end{array}$ & & & & \\
\hline & Dividend payout & $\begin{array}{l}\text { - Payable out of the } \\
\text { previous year's } \\
\text { profit and cannot } \\
\text { result in a drop } \\
\text { below any of the } \\
\text { minimum capital } \\
\text { requirements. } \\
\text { - Banks are } \\
\text { assumed to pay } \\
\text { out dividends only } \\
\text { if they report } \\
\text { profits, remain } \\
\text { above minimum } \\
\text { capital } \\
\text { requirement } \\
\text { levels and exhibit } \\
\text { a leverage ratio of } \\
\text { no less than } 3 \\
\text { percent in a given } \\
\text { year. } \\
\text { Payout rule } \\
\text { consistent with } \\
\text { maximum payout } \\
\text { ratios defined } \\
\text { under Basel III. }\end{array}$ & $\begin{array}{l}\text { - Constant dividend } \\
\text { payout (at current } \\
\text { levels until capital } \\
\text { ratio target is } \\
\text { met). }\end{array}$ & $\begin{array}{l}\text { - Endogenous to } \\
\text { market } \\
\text { expectations } \\
\text { implied by equity } \\
\text { cash and } \\
\text { derivative prices. }\end{array}$ & $\begin{array}{l}\text { - Historical figures } \\
\text { must be provided } \\
\text { for computation. } \\
\text { - In the adverse } \\
\text { scenario, the } \\
\text { payout ratio is in } \\
\text { line with the } \\
\text { median of the last } \\
\text { three years. }\end{array}$ & $\begin{array}{l}\text { - Bank's own } \\
\text { assumptions about } \\
\text { dividend payout in } \\
\text { profitable and } \\
\text { unprofitable years. }\end{array}$ \\
\hline & Asset disposal & $\begin{array}{l}\text { - Disallowed except } \\
\text { where agreed } \\
\text { with legally } \\
\text { binding }\end{array}$ & \multicolumn{2}{|l|}{ - No asset disposals. } & $\begin{array}{l}\text { Disallowed except } \\
\text { for restructuring } \\
\text { plans agreed with } \\
\text { the European }\end{array}$ & $\begin{array}{l}\text { - Banks' own } \\
\text { assumptions about } \\
\text { asset disposals in } \\
\text { line with current }\end{array}$ \\
\hline
\end{tabular}

CInternational Monetary Fund. Not for Redistribution 


\begin{tabular}{|c|c|c|c|c|c|c|}
\hline \multirow[t]{3}{*}{ Domain } & \multirow[t]{3}{*}{ Element } & \multicolumn{5}{|c|}{ Assumptions Made in Stress Tests } \\
\hline & & \multicolumn{3}{|c|}{ FSAP Update } & EBA & FSA 1/ \\
\hline & & $\begin{array}{c}\text { Bottom-Up by } \\
\text { Banks }\end{array}$ & $\begin{array}{l}\text { Top-Down by } \\
\text { Authorities }\end{array}$ & $\begin{array}{l}\text { Top-Down by } \\
\text { FSAP Team }\end{array}$ & $\begin{array}{c}\text { Bottom-Up by U.K. } \\
\text { Banks }\end{array}$ & $\begin{array}{c}\text { Bottom-Up by U.K. } \\
\text { Banks }\end{array}$ \\
\hline & & $\begin{array}{l}\text { commitments } \\
\text { under European } \\
\text { Commission state } \\
\text { aid rules. } \\
\text { - Maturing } \\
\text { exposures are } \\
\text { assumed to be } \\
\text { replaced. }\end{array}$ & & & $\begin{array}{l}\text { Commission or } \\
\text { other legally } \\
\text { binding } \\
\text { agreements or } \\
\text { plans publicly } \\
\text { disclosed before } \\
\text { April } 30,2011 .\end{array}$ & $\begin{array}{l}\text { business plans } \\
\text { which may be } \\
\text { amended under } \\
\text { stress. }\end{array}$ \\
\hline & $\begin{array}{l}\text { Lending } \\
\text { standards and } \\
\text { credit balance }\end{array}$ & $\begin{array}{l}\text { - In accordance } \\
\text { with changes in } \\
\text { credit growth } \\
\text { experienced } \\
\text { during the last } \\
\text { business cycle. }\end{array}$ & $\begin{array}{l}\text { - Determined by } \\
\text { total asset growth. }\end{array}$ & - N.A. & $\begin{array}{l}\text { - Defaulted assets } \\
\text { are not replaced. } \\
\text { - No charge-offs or } \\
\text { write-offs take } \\
\text { place within the } \\
\text { two year horizon. } \\
\text { - Maturing assets } \\
\text { are replaced with } \\
\text { assets having the } \\
\text { same quality and } \\
\text { risk characteristics } \\
\text { at maturity. }\end{array}$ & $\begin{array}{l}\text { - Banks' own } \\
\text { assumptions } \\
\text { regarding } \\
\text { replacement of } \\
\text { defaulted assets } \\
\text { and the credit } \\
\text { quality of replaced } \\
\text { and maturing } \\
\text { assets. }\end{array}$ \\
\hline & $\begin{array}{l}\text { Portfolio } \\
\text { allocation }\end{array}$ & \multicolumn{3}{|l|}{ - No change. } & - N.A. & $\begin{array}{l}\text { - Banks' own } \\
\text { assumptions about } \\
\text { what they would do } \\
\text { under the specified } \\
\text { scenario. } \\
\end{array}$ \\
\hline $\begin{array}{l}\text { Regulatory } \\
\text { standards }\end{array}$ & Hurdle rates & $\begin{array}{l}\text { - Solvency } \\
\text { assessed in } \\
\text { accordance with } \\
\text { the Basel III } \\
\text { schedule and the } \\
\text { FSA Interim } \\
\text { Capital Regime. }\end{array}$ & $\begin{array}{l}\text { Solvency } \\
\text { assessed in } \\
\text { accordance with } \\
\text { the Basel III } \\
\text { schedule and the } \\
\text { FSA Interim } \\
\text { Capital Regime. }\end{array}$ & $\begin{array}{l}\text { - Solvency } \\
\text { assessed in } \\
\text { accordance with } \\
\text { the Basel III } \\
\text { schedule and the } \\
\text { FSA Interim } \\
\text { Capital Regime. }\end{array}$ & $\begin{array}{l}\text { - Solvency assessed } \\
\text { in accordance with } \\
\text { the (Capital } \\
\text { Requirements } \\
\text { Directive) CRD } \\
\text { schedule. }\end{array}$ & $\begin{array}{l}\text { - Solvency assessed } \\
\text { in accordance with } \\
\text { the Basel } 2.5 \text { and } \\
\text { Basel III schedule. }\end{array}$ \\
\hline
\end{tabular}

CInternational Monetary Fund. Not for Redistribution 


\begin{tabular}{|c|c|c|c|c|c|c|}
\hline \multirow[t]{3}{*}{ Domain } & \multirow[t]{3}{*}{ Element } & \multicolumn{5}{|c|}{ Assumptions Made in Stress Tests } \\
\hline & & \multicolumn{3}{|c|}{ FSAP Update } & \multirow{2}{*}{$\begin{array}{c}\text { EBA } \\
\text { Bottom-Up by U.K. } \\
\text { Banks }\end{array}$} & \multirow{2}{*}{$\begin{array}{c}\text { FSA 1/ } \\
\text { Bottom-Up by U.K. } \\
\text { Banks }\end{array}$} \\
\hline & & $\begin{array}{c}\text { Bottom-Up by } \\
\text { Banks }\end{array}$ & $\begin{array}{l}\text { Top-Down by } \\
\text { Authorities }\end{array}$ & $\begin{array}{l}\text { Top-Down by } \\
\text { FSAP Team }\end{array}$ & & \\
\hline & & $\begin{array}{l}\text { Basel III hurdle } \\
\text { rates with capital } \\
\text { conservation } \\
\text { buffers are tested } \\
\text { as a sensitivity } \\
\text { check. }\end{array}$ & & & & \\
\hline & $\begin{array}{l}\text { Definition of } \\
\text { capital }\end{array}$ & $\begin{array}{l}\text { - Starting point is in } \\
\text { line with FSA } \\
\text { definitions as laid } \\
\text { out in the FSA } \\
\text { Handbook and } \\
\text { the definition of } \\
\text { capital in the FSA } \\
\text { Interim Capital } \\
\text { Regime. } \\
\text { - Phase-in of } \\
\text { capital } \\
\text { deductions. } \\
\text { - Phase-out of non- } \\
\text { core Tier } 1 \text { and } \\
\text { Tier } 2 \text { capital } \\
\text { elements. } \\
\text { - Existing capital } \\
\text { instruments are } \\
\text { not } \\
\text { grandfathered. }\end{array}$ & $\begin{array}{l}\text { Basel II- } \\
\text { consistent } \\
\text { definition of } \\
\text { capital. }\end{array}$ & $\begin{array}{l}\text { - Common equity } \\
\text { (Tier 1). }\end{array}$ & $\begin{array}{l}\text { - The definition of } \\
\text { capital is based on } \\
\text { existing EU } \\
\text { legislation in the } \\
\text { Capital } \\
\text { Requirements } \\
\text { Directive; } \\
\text { specifically in the } \\
\text { way it allows } \\
\text { capital } \\
\text { participation in } \\
\text { other financial } \\
\text { institutions to be } \\
\text { included. } \\
\text { - All hybrid } \\
\text { instruments and } \\
\text { preference shares } \\
\text { are ruled out, } \\
\text { - Government } \\
\text { support measures } \\
\text { put in place after } \\
\text { the start of the } \\
\text { financial crisis are } \\
\text { recognized, } \\
\text { except if they } \\
\text { expire before the }\end{array}$ & $\begin{array}{l}\text { - Starting point is in } \\
\text { line with FSA } \\
\text { definitions as laid } \\
\text { out in the FSA } \\
\text { Handbook and the } \\
\text { definition of Core } \\
\text { Tier I in the FSA's } \\
\text { Interim Capital } \\
\text { Regime. } \\
\text { - Government } \\
\text { support measures } \\
\text { put in place after } \\
\text { the start of the } \\
\text { financial crisis are } \\
\text { recognized }\end{array}$ \\
\hline
\end{tabular}

CInternational Monetary Fund. Not for Redistribution 


\begin{tabular}{|c|c|c|c|c|c|c|}
\hline \multirow[t]{3}{*}{ Domain } & \multirow[t]{3}{*}{ Element } & \multicolumn{5}{|c|}{ Assumptions Made in Stress Tests } \\
\hline & & \multicolumn{3}{|c|}{ FSAP Update } & \multirow{2}{*}{\begin{tabular}{|c|} 
EBA \\
Bottom-Up by U.K. \\
Banks
\end{tabular}} & \multirow{2}{*}{$\begin{array}{c}\text { FSA 1/ } \\
\text { Bottom-Up by U.K. } \\
\text { Banks }\end{array}$} \\
\hline & & $\begin{array}{c}\text { Bottom-Up by } \\
\text { Banks }\end{array}$ & $\begin{array}{c}\text { Top-Down by } \\
\text { Authorities }\end{array}$ & $\begin{array}{l}\text { Top-Down by } \\
\text { FSAP Team }\end{array}$ & & \\
\hline & & & & & end of 2012. & \\
\hline & RWAs & $\begin{array}{l}\text { - Changes in risk } \\
\text { weights for all risk } \\
\text { types increase at } \\
\text { the same rate as } \\
\text { baseline nominal } \\
\text { GDP growth } \\
\text { throughout period. } \\
\text { - Risk weights for } \\
\text { credit risk } \\
\text { reduced by the } \\
\text { RWAs of } \\
\text { defaulted } \\
\text { exposures. }\end{array}$ & $\begin{array}{l}\text { - No change in risk } \\
\text { weights. } \\
\text { - Balance sheet } \\
\text { growth as above. }\end{array}$ & $\begin{array}{l}\text { RWAs are } \\
\text { endogenous to } \\
\text { market valuation } \\
\text { of bank risk. }\end{array}$ & $\begin{array}{l}\text { - The RWAs for the } \\
\text { standardized } \\
\text { portfolios are } \\
\text { calculated based } \\
\text { on the scenarios } \\
\text { assuming rating } \\
\text { migration as } \\
\text { appropriate. } \\
\text { - The RWAs on } \\
\text { securitization } \\
\text { positions will be } \\
\text { stress according to } \\
\text { a pre-defined } \\
\text { migration of the } \\
\text { exposures by end- } \\
2012 \text { in the } \\
\text { different rating } \\
\text { classes. } \\
\text { - The RWAs on } \\
\text { market risk are } \\
\text { considered stable. } \\
\text { - Operational risk is } \\
\text { taken into account } \\
\text { by computing a } \\
\text { proxy of year-on- } \\
\text { year changes in } \\
\text { operating profit. }\end{array}$ & $\begin{array}{l}\text { - Changes in RWAs } \\
\text { under the FSA } \\
\text { macroeconomic } \\
\text { scenario based on } \\
\text { banks' approaches } \\
\text { to estimating } \\
\text { RWAs for credit, } \\
\text { securitization, } \\
\text { market and } \\
\text { operational risk } \\
\text { taking account of } \\
\text { their approved } \\
\text { approaches for } \\
\text { Pillar } 1 \text { and their } \\
\text { own assumptions } \\
\text { about rating } \\
\text { migration, change } \\
\text { in asset mix and } \\
\text { changes to } \\
\text { operating profit } \\
\text { from base case } \\
\text { assumptions. }\end{array}$ \\
\hline
\end{tabular}

Prepared by: BoE; FSA; and IMF staff.

1/ The FSA's stress testing framework for major UK banking groups involves a bottom up stress test by individual banking groups based on a designated macroeconomic scenario covering a 5 year horizon. Banks' results reflect each banking groups own methodologies and assumptions. In parallel, the FSA undertakes its own stress testing using banks' data applying internally approved methodologies as well as expert judgmental overlays to bank results.

\section{(CInternational Monetary Fund. Not for Redistribution}


APPENdiX II. Comparison of CAPITAl DEFINitions-BASEl, EBA, FSA AND U.K. FSAP UPDATE

\begin{tabular}{|c|c|c|c|c|c|c|}
\hline Capital Component & Basel II & Basel III & EBA & $\begin{array}{c}\text { FSA General } \\
\text { Prudential } \\
\text { Sourcebook }\end{array}$ & $\begin{array}{c}\text { FSA Interim Capital } \\
\text { Regime/ } \\
\text { Definition for FSAP } \\
\text { Bottom-Up Stress } \\
\text { Testing }\end{array}$ & Comments \\
\hline Core Tier 1 & $\begin{array}{l}\text { - Ordinary shares. } \\
\text { - Retained } \\
\text { earnings and } \\
\text { reserves. } \\
\text { - Share premium } \\
\text { account. } \\
\text { - Minority } \\
\text { Interests. } \\
\\
\text { - Externally } \\
\text { verified interim } \\
\text { net profits. }\end{array}$ & $\begin{array}{l}\text { - Ordinary shares. } \\
\text { - Retained } \\
\text { earnings and } \\
\text { reserves. } \\
\text { - Share premium } \\
\text { account relating } \\
\text { to CT1 } \\
\text { instruments. } \\
\text { - Minority Interests } \\
\text { (subject to } \\
\text { limits). } \\
\text { - Interim net } \\
\text { profits. }\end{array}$ & $\begin{array}{l}\text { - Ordinary shares. } \\
\text { - Retained } \\
\text { earnings and } \\
\text { reserves. } \\
\text { - Share premium } \\
\text { account relating } \\
\text { to CT1 } \\
\text { instruments. } \\
\text { - Minority } \\
\text { Interests. } \\
\text { - Externally } \\
\text { verified interim } \\
\text { net profits. } \\
\text { - Existing } \\
\text { government } \\
\text { support } \\
\text { measures } \\
\text { counted as CT1. }\end{array}$ & $\begin{array}{l}\text { - Ordinary shares. } \\
\text { - Retained } \\
\text { earnings and } \\
\text { reserves. } \\
\text { - Share premium } \\
\text { account relating } \\
\text { to CT1 } \\
\text { instruments. } \\
\text { - Minority } \\
\text { Interests. } \\
\text { - Externally } \\
\text { verified interim } \\
\text { net profits. }\end{array}$ & $\begin{array}{l}\text { - Ordinary shares. } \\
\text { - Retained } \\
\text { earnings and } \\
\text { reserves. } \\
\text { - Share premium } \\
\text { account relating } \\
\text { to CT1 } \\
\text { instruments. } \\
\text { - Minority } \\
\text { Interests. } \\
\text { - Externally } \\
\text { verified interim } \\
\text { net profits. }\end{array}$ & \\
\hline Core Tier 1 Filters & & & $\begin{array}{l}\text { - Existing national } \\
\text { filters - see FSA } \\
\text { GENPRU } \\
\text { column for UK } \\
\text { filters. }\end{array}$ & $\begin{array}{l}\text { - Pension deficit } \\
\text { net of deficit } \\
\text { reduction amount } \\
\text { (if DRA approach } \\
\text { chosen). } \\
\text { - Unrealized gains } \\
\text { on AFS equities. } \\
\text { - Unrealized gains } \\
\text { on Investment } \\
\text { property. }\end{array}$ & $\begin{array}{l}\text { - Pension deficit } \\
\text { net of deficit } \\
\text { reduction amount } \\
\text { (if DRA approach } \\
\text { chosen). } \\
\text { - Unrealized gains } \\
\text { on AFS equities. } \\
\text { - Unrealized gains } \\
\text { on Investment } \\
\text { property. }\end{array}$ & \\
\hline
\end{tabular}




\begin{tabular}{|c|c|c|c|c|c|c|}
\hline Capital Component & Basel II & Basel III & EBA & $\begin{array}{c}\text { FSA General } \\
\text { Prudential } \\
\text { Sourcebook }\end{array}$ & $\begin{array}{l}\text { FSA Interim Capital } \\
\text { Regime/ } \\
\text { Definition for FSAP } \\
\text { Bottom-Up Stress } \\
\text { Testing }\end{array}$ & Comments \\
\hline & & $\begin{array}{l}\text { - Cash-flow hedge } \\
\text { reserve not fair- } \\
\text { valued on } \\
\text { balance sheet. } \\
\text { - Gain on sale } \\
\text { related to } \\
\text { securitization } \\
\text { transactions. } \\
\text { - Cumulative gains } \\
\text { and losses due } \\
\text { to changes in } \\
\text { own credit risk } \\
\text { on fair valued } \\
\text { financial } \\
\text { liabilities. }\end{array}$ & & $\begin{array}{l}\text { - Unrealized gains } \\
\text { on land and } \\
\text { buildings. } \\
\text { - Unrealized } \\
\text { losses (gains) on } \\
\text { AFS debt. } \\
\text { - Cash-flow hedge } \\
\text { reserve not fair- } \\
\text { valued on } \\
\text { balance sheet. } \\
\text { - Gain on sale } \\
\text { related to } \\
\text { securitization } \\
\text { transactions. } \\
\text { - Cumulative gains } \\
\text { and losses due to } \\
\text { changes in own } \\
\text { credit risk on fair } \\
\text { valued financial } \\
\text { liabilities. }\end{array}$ & $\begin{array}{l}\text { - Unrealized gains } \\
\text { on land and } \\
\text { buildings. } \\
\text { - Unrealized } \\
\text { losses (gains) on } \\
\text { AFS debt. } \\
\text { - Cash-flow hedge } \\
\text { reserve not fair- } \\
\text { valued on } \\
\text { balance sheet. } \\
\text { - Gain on sale } \\
\text { related to } \\
\text { securitization } \\
\text { transactions. } \\
\text { - Cumulative gains } \\
\text { and losses due } \\
\text { to changes in } \\
\text { own credit risk } \\
\text { on fair valued } \\
\text { financial } \\
\text { liabilities. }\end{array}$ & \\
\hline $\begin{array}{l}\text { Deductions from } \\
\text { Core Tier } 1\end{array}$ & - Interim net losses & $\begin{array}{l}\text { - Interim net } \\
\text { losses. } \\
\text { - Intangibles } \\
\text { including } \\
\text { goodwill (limited } \\
\text { recognition of } \\
\text { mortgage } \\
\text { servicing rights). } \\
\text { - Investments in } \\
\text { own shares. }\end{array}$ & $\begin{array}{l}\text { - Interim net } \\
\text { losses. } \\
\text { - Intangibles } \\
\text { including } \\
\text { goodwill. } \\
\text { - Investments in } \\
\text { own shares. } \\
\text { - } 50 \text { percent } \\
\text { shortfall in stock } \\
\text { of provisions to }\end{array}$ & $\begin{array}{l}\text { - Interim net } \\
\text { losses. }\end{array}$ & \begin{tabular}{|l} 
- Interim net \\
losses. \\
- Intangibles \\
including \\
goodwill. \\
- Investments in \\
own shares. \\
- 50 percent \\
shortfall in stock \\
of provisions to
\end{tabular} & \\
\hline
\end{tabular}




\begin{tabular}{|c|c|c|c|c|c|c|}
\hline Capital Component & Basel II & Basel III & EBA & $\begin{array}{c}\text { FSA General } \\
\text { Prudential } \\
\text { Sourcebook }\end{array}$ & $\begin{array}{c}\text { FSA Interim Capital } \\
\text { Regime/ } \\
\text { Definition for FSAP } \\
\text { Bottom-Up Stress } \\
\text { Testing }\end{array}$ & Comments \\
\hline & & $\begin{array}{l}\text { - Shortfall of the } \\
\text { stock of } \\
\text { provisions to } \\
\text { expected losses. } \\
\\
\text { - Defined benefit } \\
\text { pension fund } \\
\text { assets and } \\
\text { liabilities (include } \\
\text { liabilities in full, } \\
\text { deduct assets). } \\
\text { Deferred tax } \\
\text { assets (limited } \\
\text { recognition } \\
\text { allowed). } \\
\text { - Reciprocal cross } \\
\text { holdings in the } \\
\text { common stock of } \\
\text { banking, financial } \\
\text { and insurance } \\
\text { entities. } \\
\text { Investments in } \\
\text { the common } \\
\text { stock of banking, } \\
\text { financial and } \\
\text { insurance } \\
\text { entities that are } \\
\text { outside the } \\
\text { scope of } \\
\text { and }\end{array}$ & $\begin{array}{l}\text { expected losses. } \\
\text { - } 50 \text { percent } \\
\text { certain } \\
\text { securitization } \\
\text { exposures. } \\
\\
\text { - } \text { Certain qualifying } \\
\text { holdings. } \\
50 \text { percent } \\
\text { material holdings } \\
\text { in financial } \\
\text { institutions } \\
\text { (excluding } \\
\text { material } \\
\text { insurance } \\
\text { holdings). } \\
50 \text { percent free } \\
\text { deliveries. }\end{array}$ & & $\begin{array}{l}\text { expected losses. } \\
\text { - } 50 \text { percent } \\
\text { certain } \\
\text { securitization } \\
\text { exposures. }\end{array}$ & \\
\hline
\end{tabular}

CInternational Monetary Fund. Not for Redistribution 


\begin{tabular}{|c|c|c|c|c|c|c|}
\hline Capital Component & Basel II & Basel III & EBA & $\begin{array}{l}\text { FSA General } \\
\text { Prudential } \\
\text { Sourcebook }\end{array}$ & $\begin{array}{c}\text { FSA Interim Capital } \\
\text { Regime/ } \\
\text { Definition for FSAP } \\
\text { Bottom-Up Stress } \\
\text { Testing } \\
\end{array}$ & Comments \\
\hline & & $\begin{array}{l}\text { regulatory } \\
\text { consolidation } \\
\text { and where the } \\
\text { bank does not } \\
\text { own more than } \\
10 \text { percent of the } \\
\text { issued common } \\
\text { share capital of } \\
\text { the entity (the } \\
\text { amount held } \\
\text { above } 10 \text { percent } \\
\text { to be deducted, } \\
\text { based on the } \\
\text { ratio held in } \\
\text { common stock). } \\
\text { Significant } \\
\text { investments in } \\
\text { the common } \\
\text { stock of banking, } \\
\text { financial and } \\
\text { insurance } \\
\text { entities that are } \\
\text { outside the } \\
\text { scope of } \\
\text { regulatory } \\
\text { consolidation } \\
\text { (limited } \\
\text { recognition } \\
\text { allowed). }\end{array}$ & & & & \\
\hline Tier 1 & $\begin{array}{l}\text { - Perpetual non- } \\
\text { cumulative } \\
\text { preference }\end{array}$ & $\begin{array}{l}\text { "Additional Tier } \\
\text { 1" instruments } \\
\text { without any }\end{array}$ & $\begin{array}{l}\text { - Non cumulative } \\
\text { preference } \\
\text { shares. }\end{array}$ & $\begin{array}{l}\text { - Hybrid } \\
\text { instruments } \\
\text { without }\end{array}$ & $\begin{array}{l}\text { - Hybrid } \\
\text { instruments } \\
\text { without }\end{array}$ & \\
\hline
\end{tabular}

CInternational Monetary Fund. Not for Redistribution 


\begin{tabular}{|c|c|c|c|c|c|c|}
\hline Capital Component & Basel II & Basel III & EBA & $\begin{array}{l}\text { FSA General } \\
\text { Prudential } \\
\text { Sourcebook }\end{array}$ & $\begin{array}{c}\text { FSA Interim Capital } \\
\text { Regime/ } \\
\text { Definition for FSAP } \\
\text { Bottom-Up Stress } \\
\text { Testing }\end{array}$ & Comments \\
\hline & $\begin{array}{l}\text { shares. } \\
\text { - Innovative hybrid } \\
\text { instruments } \\
\text { allowing } \\
\text { incentives to } \\
\text { redeem. }\end{array}$ & $\begin{array}{l}\text { incentive to } \\
\text { redeem. }\end{array}$ & $\begin{array}{l}\text { - Innovative hybrid } \\
\text { instruments with } \\
\text { incentives to } \\
\text { redeem. }\end{array}$ & $\begin{array}{l}\text { incentives to } \\
\text { redeem. } \\
\text { - Innovative hybrid } \\
\text { instruments } \\
\text { allowing } \\
\text { incentives to } \\
\text { redeem. }\end{array}$ & $\begin{array}{l}\text { incentives to } \\
\text { redeem. } \\
\text { - Innovative hybrid } \\
\text { instruments } \\
\text { allowing } \\
\text { incentives to } \\
\text { redeem. }\end{array}$ & \\
\hline Tier 1 Filters & & & & $\begin{array}{l}\text { - Net loss on AFS } \\
\text { equities. }\end{array}$ & & \\
\hline $\begin{array}{l}\text { Deductions from } \\
\text { Tier } 1\end{array}$ & $\begin{array}{l}\text { - Goodwill. } \\
\text { - Investments in } \\
\text { own shares. } \\
\text { - } 50 \text { percent } \\
\text { certain } \\
\text { securitization } \\
\text { exposures. } \\
\text { - } 50 \text { percent } \\
\text { shortfall in stock } \\
\text { of provisions to } \\
\text { expected losses. } \\
\text { - } 50 \text { percent } \\
\text { material holdings } \\
\text { in financial } \\
\text { institutions. }\end{array}$ & $\begin{array}{l}\text { - Reciprocal cross } \\
\text { holdings in the }\end{array}$ & & $\begin{array}{l}\text { - Intangibles } \\
\text { including } \\
\text { goodwill. } \\
\text { - Investments in } \\
\text { own shares. } \\
\text { - } 50 \text { percent } \\
\text { securitization } \\
\text { positions. } \\
50 \text { percent } \\
\text { shortfall in stock } \\
\text { of provisions to } \\
\text { expected losses. } \\
\text { - } 50 \text { percent } \\
\text { material holdings } \\
\text { in financial } \\
\text { institutions. }\end{array}$ & $\begin{array}{l}\text { - } 50 \text { percent of } \\
\text { material holdings } \\
\text { in financial } \\
\text { institutions. }\end{array}$ & $\begin{array}{l}\text { Transitional } \\
\text { provisions apply to } \\
\text { insurance holdings } \\
\text { (GENPRU and } \\
\text { FSA interim } \\
\text { supervisory } \\
\text { framework) until } \\
2013 \text {. }\end{array}$ \\
\hline
\end{tabular}




\begin{tabular}{|c|c|c|c|c|c|c|}
\hline Capital Component & Basel II & Basel III & EBA & $\begin{array}{c}\text { FSA General } \\
\text { Prudential } \\
\text { Sourcebook }\end{array}$ & $\begin{array}{c}\text { FSA Interim Capital } \\
\text { Regime/ } \\
\text { Definition for FSAP } \\
\text { Bottom-Up Stress } \\
\text { Testing }\end{array}$ & Comments \\
\hline & & $\begin{array}{l}\text { AT1 of banking, } \\
\text { financial and } \\
\text { insurance } \\
\text { entities. } \\
\text { - Non-significant } \\
\text { investments in } \\
\text { the AT1 of } \\
\text { banking, financial } \\
\text { and insurance } \\
\text { entities that are } \\
\text { outside the } \\
\text { scope of } \\
\text { regulatory } \\
\text { consolidation } \\
\text { and where the } \\
\text { bank does not } \\
\text { own more than } \\
10 \text { percent of the } \\
\text { issued common } \\
\text { share capital of } \\
\text { the entity (the } \\
\text { amount held } \\
\text { above } 10 \text { percent } \\
\text { to be deducted, } \\
\text { based on the } \\
\text { ratio held in } \\
\text { AT1). } \\
\text { Significant } \\
\text { investments in } \\
\text { the AT1 of } \\
\text { banking, financial } \\
\text { and insurance }\end{array}$ & & & & \\
\hline
\end{tabular}

CInternational Monetary Fund. Not for Redistribution 


\begin{tabular}{|c|c|c|c|c|c|c|}
\hline Capital Component & Basel II & Basel III & EBA & $\begin{array}{l}\text { FSA General } \\
\text { Prudential } \\
\text { Sourcebook }\end{array}$ & $\begin{array}{c}\text { FSA Interim Capital } \\
\text { Regime/ } \\
\text { Definition for FSAP } \\
\text { Bottom-Up Stress } \\
\text { Testing }\end{array}$ & Comments \\
\hline & & $\begin{array}{l}\text { entities that are } \\
\text { outside the } \\
\text { scope of } \\
\text { regulatory } \\
\text { consolidation (full } \\
\text { deduction, } \\
\text { subject to the } \\
10 \text { percent } \\
\text { threshold). }\end{array}$ & & & & \\
\hline Upper Tier 2 & $\begin{array}{l}\text { - Perpetual } \\
\text { cumulative } \\
\text { preference } \\
\text { shares. } \\
\text { - Perpetual } \\
\text { subordinated } \\
\text { debt. } \\
\text { - Perpetual } \\
\text { subordinated } \\
\text { securities. } \\
\text { - Revaluation } \\
\text { reserves. } \\
\text { - General/collectiv } \\
\text { e provisions. } \\
\text { - Minority } \\
\text { Interests. } \\
\text { - Surplus } \\
\text { provisions. }\end{array}$ & & & $\begin{array}{l}\text { - Perpetual } \\
\text { cumulative } \\
\text { preference } \\
\text { shares. } \\
\text { - Perpetual } \\
\text { subordinated } \\
\text { debt. } \\
\text { - Perpetual } \\
\text { subordinated } \\
\text { securities. } \\
\text { - Revaluation } \\
\text { reserves. } \\
\text { - General/collectiv } \\
\text { e provisions. } \\
\text { - Minority } \\
\text { Interests. } \\
\text { - Surplus } \\
\text { provisions. }\end{array}$ & & \\
\hline Lower Tier 2 & $\begin{array}{l}\text { - Fixed term } \\
\text { preference } \\
\text { shares. }\end{array}$ & $\begin{array}{l}\text { - } \text { "Tier 2" } \\
\text { instruments. } \\
\text { - Stock surplus } \\
\text { resulting from T2 }\end{array}$ & & $\begin{array}{l}\text { Fixed term } \\
\text { preference } \\
\text { shares. }\end{array}$ & & \\
\hline
\end{tabular}




\begin{tabular}{|c|c|c|c|c|c|c|}
\hline Capital Component & Basel II & Basel III & EBA & $\begin{array}{c}\text { FSA General } \\
\text { Prudential } \\
\text { Sourcebook }\end{array}$ & $\begin{array}{c}\text { FSA Interim Capital } \\
\text { Regime/ } \\
\text { Definition for FSAP } \\
\text { Bottom-Up Stress } \\
\text { Testing }\end{array}$ & Comments \\
\hline & $\begin{array}{l}\text { - Long term } \\
\text { subordinated } \\
\text { debt. } \\
\text { - Minority } \\
\text { Interests. } \\
\text { - Fixed term } \\
\text { subordinated } \\
\text { securities. }\end{array}$ & $\begin{array}{l}\text { instruments. } \\
\text { - Certain loan loss } \\
\text { provisions. } \\
\text { - Minority Interests } \\
\text { (subject to } \\
\text { limits). }\end{array}$ & & $\begin{array}{l}\text { - Long term } \\
\text { subordinated } \\
\text { debt. } \\
\text { - Minority } \\
\text { Interests. } \\
\text { - Fixed term } \\
\text { subordinated } \\
\text { securities. }\end{array}$ & & \\
\hline $\begin{array}{l}\text { Deductions from } \\
\text { Tier } 1 \text { and Tier } 2\end{array}$ & $\begin{array}{l}\text { - Qualifying } \\
\text { holdings. } \\
\text { - } 50 \text { percent } \\
\text { material holdings. }\end{array}$ & $\begin{array}{l}\text { - Reciprocal cross } \\
\text { holdings in the } \\
\text { T2 of banking, } \\
\text { financial and } \\
\text { insurance } \\
\text { entities. } \\
\text { - Non-significant } \\
\text { investments in } \\
\text { the T2 of } \\
\text { banking, financial } \\
\text { and insurance } \\
\text { entities that are } \\
\text { outside the } \\
\text { scope of } \\
\text { regulatory } \\
\text { consolidation } \\
\text { and where the } \\
\text { bank does not } \\
\text { own more than } \\
10 \text { percent of the } \\
\text { issued common } \\
\text { share capital of } \\
\text { the entity (the } \\
\text { amount held }\end{array}$ & & $\begin{array}{l}\text { - Qualifying } \\
\text { holdings. } \\
\text { - } 50 \text { percent } \\
\text { material holdings. }\end{array}$ & & \\
\hline
\end{tabular}

CInternational Monetary Fund. Not for Redistribution 


\begin{tabular}{|c|c|c|c|c|c|c|}
\hline Capital Component & Basel II & Basel III & EBA & $\begin{array}{c}\text { FSA General } \\
\text { Prudential } \\
\text { Sourcebook }\end{array}$ & $\begin{array}{c}\text { FSA Interim Capital } \\
\text { Regime/ } \\
\text { Definition for FSAP } \\
\text { Bottom-Up Stress } \\
\text { Testing }\end{array}$ & Comments \\
\hline & $\begin{array}{l}\text { - } 50 \text { percent } \\
\text { expected loss } \\
\text { amounts and } \\
\text { other negative } \\
\text { amounts. } \\
\text { - } 50 \text { percent } \\
\text { securitization } \\
\text { positions. } \\
\\
\text { - Reciprocal cross- } \\
\text { holdings. }\end{array}$ & $\begin{array}{l}\text { above } 10 \text { percent } \\
\text { to be deducted, } \\
\text { based on the } \\
\text { ratio held in } \\
\text { AT1). } \\
\text { - Significant } \\
\text { investments in } \\
\text { the T2 of } \\
\text { banking, financial } \\
\text { and insurance } \\
\text { entities that are } \\
\text { outside the } \\
\text { scope of } \\
\text { regulatory } \\
\text { consolidation (full } \\
\text { deduction, } \\
\text { subject to the } \\
10 \text { percent } \\
\text { threshold). } \\
\text { Investments in } \\
\text { own T2. }\end{array}$ & & $\begin{array}{l}\text { - } 50 \text { percent } \\
\text { expected loss } \\
\text { amounts and } \\
\text { other negative } \\
\text { amounts. } \\
\text { - } 50 \text { percent } \\
\text { securitization } \\
\text { positions. } \\
\\
\text { - Reciprocal cross- } \\
\text { holdings. } \\
\text { Investments in } \\
\text { subsidiary } \\
\text { undertakings and } \\
\text { participations. } \\
\text { Connected } \\
\text { lending of a }\end{array}$ & & \\
\hline
\end{tabular}




\begin{tabular}{|c|c|c|c|c|c|c|}
\hline Capital Component & Basel II & Basel III & EBA & $\begin{array}{l}\text { FSA General } \\
\text { Prudential } \\
\text { Sourcebook }\end{array}$ & $\begin{array}{c}\text { FSA Interim Capital } \\
\text { Regime/ } \\
\text { Definition for FSAP } \\
\text { Bottom-Up Stress } \\
\text { Testing }\end{array}$ & Comments \\
\hline & & & & capital nature. & & \\
\hline Tier 3 & $\begin{array}{l}\text { - Short term } \\
\text { subordinated } \\
\text { debt. } \\
\text { - Net interim } \\
\text { trading book } \\
\text { profit and loss. }\end{array}$ & & & $\begin{array}{l}\text { Short term } \\
\text { subordinated } \\
\text { debt. } \\
\text { - Net interim } \\
\text { trading book } \\
\text { profit and loss. }\end{array}$ & & \\
\hline $\begin{array}{l}\text { Deductions from } \\
\text { Tier } 3\end{array}$ & $\begin{array}{l}\text { Excess trading } \\
\text { book position. } \\
\text { - Free deliveries. }\end{array}$ & & & $\begin{array}{l}\text { Excess trading } \\
\text { book position. } \\
\text { - Free deliveries. }\end{array}$ & & \\
\hline Footnotes & & $\begin{array}{l}\text { - Securitization } \\
\text { positions risk } \\
\text { weighted } \\
1250 \text { percent not } \\
\text { deducted. }\end{array}$ & $\begin{array}{l}\text { - Deduction of } \\
\text { certain } \\
\text { securitization } \\
\text { exposures is } \\
2010 \text { only, } \\
\text { unless } \\
\text { Government } \\
\text { measures apply. } \\
\text { For } 2011 \text { and } \\
2012, \\
\text { securitization } \\
\text { positions are } \\
\text { risk-weighted at } \\
1250 \text { percent. }\end{array}$ & $\begin{array}{l}\text { - Tier } 1 \text { capital } \\
\text { resources include } \\
\text { instruments that } \\
\text { are being } \\
\text { grandfathered } \\
\text { within Tier } 1 \\
\text { under CRD2 } \\
\text { transitional } \\
\text { arrangements. } \\
\text { These include } \\
\text { preference } \\
\text { shares and } \\
\text { innovative Tier } 1 \\
\text { instruments that } \\
\text { do not have a } \\
\text { principal loss } \\
\text { absorbency } \\
\text { (PLA) } \\
\text { mechanism. (A } \\
\text { suitable PLA } \\
\text { mechanism is }\end{array}$ & $\begin{array}{l}\text { - Tier } 1 \text { capital } \\
\text { resources } \\
\text { include } \\
\text { instruments that } \\
\text { are being } \\
\text { grandfathered } \\
\text { within Tier } 1 \\
\text { under CRD2 } \\
\text { transitional } \\
\text { arrangements. } \\
\text { These include } \\
\text { preference } \\
\text { shares and } \\
\text { innovative Tier } 1 \\
\text { instruments that } \\
\text { do not have a } \\
\text { principal loss } \\
\text { absorbency } \\
\text { (PLA) } \\
\text { mechanism. (A } \\
\text { suitable PLA }\end{array}$ & \\
\hline
\end{tabular}

CInternational Monetary Fund. Not for Redistribution 


\begin{tabular}{|c|c|c|c|c|c|c|}
\hline Capital Component & Basel II & Basel III & EBA & $\begin{array}{c}\text { FSA General } \\
\text { Prudential } \\
\text { Sourcebook }\end{array}$ & $\begin{array}{c}\text { FSA Interim Capital } \\
\text { Regime/ } \\
\text { Definition for FSAP } \\
\text { Bottom-Up Stress } \\
\text { Testing }\end{array}$ & Comments \\
\hline & & $\begin{array}{l}\text { - Qualifying } \\
\text { holdings risk } \\
\text { weighted } \\
\text { 1250 percent not } \\
\text { deducted. } \\
\text { Deferred tax } \\
\text { assets arising } \\
\text { from temporary } \\
\text { differences, } \\
\text { significant } \\
\text { investment in the } \\
\text { common shares } \\
\text { of }\end{array}$ & & $\begin{array}{l}\text { required for an } \\
\text { item to be eligible } \\
\text { as hybrid capital } \\
\text { under CRD2, as } \\
\text { implemented in } \\
\text { GENPRU.) } \\
\text { However, such } \\
\text { instruments } \\
\text { issued prior to } \\
31 / 12 / 10 \\
\text { currently } \\
\text { continue to count } \\
\text { towards Tier } 1 \\
\text { subject to the } \\
\text { limits in place in } \\
\text { GENPRU prior to } \\
\text { that date. }\end{array}$ & $\begin{array}{l}\text { mechanism is } \\
\text { required for an } \\
\text { item to be } \\
\text { eligible as hybrid } \\
\text { capital under } \\
\text { CRD2, as } \\
\text { implemented in } \\
\text { GENPRU.) } \\
\text { However, such } \\
\text { instruments } \\
\text { issued prior to } \\
31 / 12 / 10 \\
\text { currently } \\
\text { continue to count } \\
\text { towards Tier } 1 \\
\text { subject to the } \\
\text { limits in place in } \\
\text { GENPRU prior to } \\
\text { that date. }\end{array}$ & \\
\hline
\end{tabular}

CInternational Monetary Fund. Not for Redistribution 


\begin{tabular}{|c|c|c|c|c|c|c|}
\hline Capital Component & Basel II & Basel III & EBA & $\begin{array}{l}\text { FSA General } \\
\text { Prudential } \\
\text { Sourcebook }\end{array}$ & $\begin{array}{c}\text { FSA Interim Capital } \\
\text { Regime/ } \\
\text { Definition for FSAP } \\
\text { Bottom-Up Stress } \\
\text { Testing }\end{array}$ & Comments \\
\hline & & $\begin{array}{l}\text { unconsolidated } \\
\text { financial } \\
\text { institutions, and } \\
\text { mortgage } \\
\text { servicing rights } \\
\text { allowed up to } \\
10 \text { percent of } \\
\text { CT1 each but } \\
15 \text { percent limit } \\
\text { in aggregate. }\end{array}$ & & & & \\
\hline References & $\begin{array}{l}\text { - Capital } \\
\text { Requirements } \\
\text { Directive. 1/ }\end{array}$ & $\begin{array}{l}\text { December } 2010 \\
\text { final Basel } \\
\text { capital } \\
\text { framework } \\
\text { proposals. 2/ }\end{array}$ & - EBA definition. 3/ & $\begin{array}{l}\text { - FSA Handbook. } \\
\text { 4/ }\end{array}$ & $\begin{array}{l}\text { BBA letter from } \\
\text { Paul Sharma. 5/ }\end{array}$ & \\
\hline
\end{tabular}

Prepared by: FSA.

1/ http://ec.europa.eu/internal_market/bank/regcapital/index_en.htm\#crd.

2/ http://www.bis.org/publ/bcbs189.htm.

3/ http://www.eba.europa.eu/News--Communications/Year/2011/The-EBA-publishes-details-of-its-stress-test-scena.aspx.

4/ http://fsahandbook.info/FSA/html/handbook/GENPRU/2/Annex2.

5/ http://www.fsa.gov.uk/pubs/other/bba_letter.pdf. 


\section{APPENDIX III. PARAMETERS APPLIED IN THE U.K. FSAP UPDATE LIQUIDITY STRESS TESTS}

\begin{tabular}{|c|c|c|c|c|}
\hline \multirow[t]{2}{*}{ Test } & \multirow[t]{2}{*}{ Definition } & \multicolumn{2}{|c|}{ Basic Assumptions } & \multirow[t]{2}{*}{ Other Assumptions } \\
\hline & & Asset Side (Cash inflows) & Liabilities (Cash outflows) & \\
\hline & \multicolumn{4}{|c|}{ Implied Cash Flow Test } \\
\hline 5 -day test & $\begin{array}{l}\text { Consecutive outflow } \\
\text { of liabilities over five } \\
\text { days. }\end{array}$ & $\begin{array}{l}\text { Asset that remain liquid under stress and haircuts (one-off): } \\
\text { (i) cash and cash-equivalent positions (haircut: } 0 \text { percent); } \\
\text { (ii) government debt holdings; (0), (iii) investments (securities) } \\
\text { (20); (iv) trading securities (20); (v) derivatives (50); (v) high- } \\
\text { quality investment securities (1); and (vii) secured assets (up to } \\
\text { one month) (1). } \\
\text { Asset that remain liquid under stress and haircuts (one-off): } \\
\text { (i) cash and cash-equivalent positions (0); (ii) government debt } \\
\text { holdings (1); (iii) investments (securities) (10); (iv) trading } \\
\text { securities (40); (v) derivatives (50); (vi) high-quality investment } \\
\text { securities (5); and (vii) secured assets (up to one month) (75). }\end{array}$ & $\begin{array}{l}\text { (i) demand deposits by non-financial/financial entities }(50 / 75) \text {; } \\
\text { (ii) term deposits by non-financial/financial entities }(20 / 30) \text {; } \\
\text { (iii) secured/unsecured wholesale funding ( } 40 / 50) \text {; and } \\
\text { (iv) intragroup funding (20). }\end{array}$ & $\begin{array}{l}10 \text { percent of the liquid assets are } \\
\text { encumbered, i.e., used as a collateral to } \\
\text { receive funding (with the exception of } \\
\text { cash/cash-equivalents); no offsetting cash } \\
\text { inflows from wholesale lending (at contractual } \\
\text { maturities); no inflows of interbank lending in } \\
\text { times of stress; no consideration of access to } \\
\text { the Bank of England discount window. }\end{array}$ \\
\hline \multirow[t]{2}{*}{ Memo item } & \multicolumn{4}{|c|}{$\begin{array}{l}\text { The FSA does not complete tests that are directly comparable to these results due to a process of individualized liquidity risk monitoring. However, the survival day metric monitored by the FSA to assess } \\
\text { vulnerabilities to wholesale funding is broadly similar to the } 30 \text {-day test. The FSA collects daily cash flow data for three months from the reporting date in respect of wholesale secured and unsecured cash flows to } \\
\text { assess if a firm can withstand lock-out in wholesale funding markets by using a stock of high-quality marketable assets. High-quality assets constitute the following type of assets: liquid assets as set out in FSA } \\
\text { BIPRU 12.7, other central bank and government securities rates above "credit step } 1 \text { " and securities issued by U.S. GSE/GSAs. Wholesale cumulative funding gap is calculated by using the daily inflows and } \\
\text { outflows. The stock of high quality buffer assets, which a firm holds or will receive in repo operations, is added to this cumulative gap to calculate cash flow gap after accounting for high-quality collateral. Survival } \\
\text { days are defined as the first day on which the cumulative wholesale refinancing gap after adding the high quality assets turns negative. For this exercise, the FSA finds that } 75 \text { percent of all firms in the full sample }\end{array}$} \\
\hline & \multicolumn{4}{|c|}{ Proposed Basel III Measures } \\
\hline $\begin{array}{l}\text { Quasi-Liquidity } \\
\text { Coverage Ratio (LCR) }\end{array}$ & $\begin{array}{l}\text { Stock of high-quality } \\
\text { liquid assets would } \\
\text { need to cover short- } \\
\text { term net cash } \\
\text { outflows. }\end{array}$ & $\begin{array}{l}\text { Assets that remain liquid under stress: (i) high-quality bonds } \\
\text { and covered bonds (rated "AA-" and higher) (15); sovereign, } \\
\text { central bank and PSE assets qualifying for } 20 \text { percent risk- } \\
\text { weighting (15). }\end{array}$ & $\begin{array}{l}\text { (i) term deposits with residual maturity > } 1 \text { month (0); } \\
\text { (ii) stable/less stable retail deposits ( } 5 / 10) \text {; (iii) unsecured } \\
\text { wholesale funding with/without operational relationship/funding } \\
\text { from other entities (financial institutions) ( } 25 / 75 / 100) \text {; } \\
\text { (iv) percentage of interbank market funding secured with illiquid } \\
\text { assets (100); (v) secured funding backed by "Level 1" } \\
\text { assets/"Level 2" assets and by other valuable assets (close to } \\
\text { "Level 2") (0/15/25); (vi) portion of high-quality liquid asset } \\
\text { needed to satisfy margin calls (10); and (vii) market value } \\
\text { change on derivatives (20). }\end{array}$ & $\begin{array}{l}\text { (i) asset-backed assets maturing within } 30 \\
\text { days (10); (ii) portion of undrawn but } \\
\text { committed funding liabilities that are drawn } \\
\text { ( } 50 \text { ); (iii) portion of assets reinvested (20); and } \\
\text { (iv) renewal rate for amortizing loans and other } \\
\text { assets (100); no inflows of interbank lending } \\
\text { in times of stress, and no consideration of } \\
\text { access to the Bank of England discount } \\
\text { window. }\end{array}$ \\
\hline $\begin{array}{l}\text { Quasi-Net Stable } \\
\text { Funding Ratio (NSFR) }\end{array}$ & $\begin{array}{l}\text { Available stable } \\
\text { sources of funding } \\
\text { need to exceed the } \\
\text { required level of } \\
\text { required funding. }\end{array}$ & 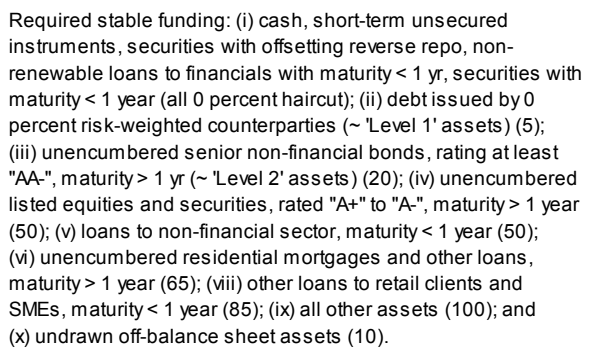 & $\begin{array}{l}\text { Available stable funding: (i) capital and long-term debt }(>1 \text { year) } \\
\text { (100); (ii) stable deposits of retail and SMEs }(<1 \text { year) }(90) ; \\
\text { (iii) less stable deposits of retail and SMEs }(<1 \text { year) }(80) ; \\
\text { (iv) wholesale funding provided by non-financials }(<1 \text { year) (50); } \\
\text { and (v) all other liabilities ( } 0 \text { ). }\end{array}$ & $\begin{array}{l}\text { No inflows of interbank lending in times of } \\
\text { stress, and no consideration of access to the } \\
\text { Bank of England discount window. }\end{array}$ \\
\hline
\end{tabular}




\section{Appendix IV. The Contingent Claims Analysis ApProaCh: STANDARd DeFinition}

\section{CCA is used to construct risk-adjusted balance sheets, based on three principles.}

The principles are: (i) the values of liabilities (equity and debt) are derived from assets; (ii) liabilities have different priority (i.e., senior and junior claims); and, (iii) assets follow a stochastic process. Assets (for example, present value of income flows, and proceeds from assets sales) are stochastic and over a horizon period may be above or below promised payments on debt which constitute a default barrier. Uncertain changes in future asset value, relative to the default barrier, are the driver of default risk which occurs when assets decline below the barrier. When there is a chance of default, the repayment of debt is considered "risky," to the extent that it is not guaranteed in the event of default (risky debt $=$ risk-free debt minus guarantee against default). The guarantee can be held by the debt holder, in which case it can be thought of as the expected loss from possible default or by a third party guarantor, such as the government.

44. In the first structural specification, commonly referred to as the Black-ScholesMerton (BSM) framework (or short "Merton model") of capital structure-based option pricing theory (OPT), total value of firm assets follows a stochastic process may fall below the value of outstanding liabilities. ${ }^{13}$ Thus, the asset value $A(t)$ at time $t$ describes a continuous asset process so that the physical probability distribution of the end-of-period value is:

$$
A(T-t) \sim A(t) \exp \left\{\left(r_{A}+\sigma_{A}^{2} / 2\right)(T-t)+\sigma_{A} \sqrt{T-t} r\right\}
$$

for time to maturity $T$ - $t$. More specifically, $A(t)$ is equal to the sum of its equity market value, $E(t)$, and its risky debt, $D(t)$, so that $A(t)=E(t)+D(t)$. Default occurs if $A(t)$ is insufficient to meet the amount of debt owed to creditors at maturity, which constitute the bankruptcy level ("default threshold" or "distress barrier"). The equity value $E(t)$ is the value of an implicit call option on the assets, with an exercise price equal to default barrier. It can be computed as the value of a call option $E(t)=A(t) \Phi\left(d_{1}\right)-B e^{-r(T-t)} \Phi\left(d_{2}\right)$, with $d_{1}=\left[\ln (A(t) / B)+\left(r+\sigma_{A}^{2} / 2\right)(T-t)\right]\left(\sigma_{A} \sqrt{T-t}\right)^{-1}, d_{2}=d_{1}-\sigma_{A} \sqrt{T-t}$, asset return volatility $\sigma_{A}$, and the cumulative probability $\Phi($.$) of the standard normal density function. Both the asset,$ $A(t)$, and asset volatility, $\sigma_{A}$, are valued after the dividend payouts. The value of risky debt is equal to default-free debt minus the present value of expected loss due to default,

\footnotetext{
${ }^{13}$ See Black and Scholes (1973) and Merton (1973, 1974).
} 
$D(t)=B e^{-r(T-t)}-P_{E}(t)$.

45. Thus, the present value of market-implied potential losses associated with outstanding liabilities can be valued as an implicit put option, which is calculated with the default threshold $B$ as strike price on the asset value $A(t)$ of each institution. Thus, the present value of market-implied potential loss can be computed as:

$$
P_{E}(t)=B e^{-r(T-t)} \Phi\left(-d_{2}\right)-A(t) \Phi\left(-d_{1}\right)
$$

over time horizon $T-t$ at risk-free discount rate $r$, subject to the duration of debt claims, the leverage of the firm, and asset volatility. Note that the above option pricing method for $P_{E}(t)$ does not incorporate skewness, kurtosis, and stochastic volatility, which can account for implied volatility smiles of equity prices. Since the implicit put option $P_{E}(t)$ can be decomposed into the PD and LGD,

$$
P_{E}=\Phi\left(-d_{2}\right)\left(1-\frac{\Phi\left(-d_{1}\right)}{\Phi\left(-d_{2}\right)} \frac{A(t)}{B e^{-r T}}\right) B e^{-r(T-t)}=P D \times L G D,
$$

there is no need to introduce potential inaccuracy of assuming a certain LGD. As a consequence of the assumptions on the underlying asset price process, this would imply the risk-neutral probability distribution (or state price density, SPD) of $A(t)$ is a log-normal density:

$$
\begin{aligned}
& f_{t}^{*}(A(T))=\left.e^{-r_{t, T-t} T-t} \frac{\partial^{2} E(t)}{\partial B^{2}}\right|_{B=A(T)} \\
& =\frac{1}{A(T) \sqrt{2 \pi \sigma^{2}(T-t)}} \exp \left[-\frac{\left[\ln (A(T) / A(t))-\left(r_{t, T-t}-\sigma^{2} / 2\right)(T-t)\right]^{2}}{2 \sigma^{2}(T-t)}\right]
\end{aligned}
$$

with mean $\left(r-\sigma_{A}^{2} / 2\right)(T-t)$ and variance $\sigma_{A}^{2}(T-t)$ for $\ln (A(T) / A(t))$, where ${ }^{r_{t, T-t}}$ and $f^{*}($.$) denote the risk-free interest rate and the risk-neutral probability density function (or$ $\mathrm{SPD})$ at time $t$, with risk measures:

$$
\Delta \stackrel{\text { def }}{=} \frac{\partial E(t)}{\partial A(t)}=\Phi\left(d_{1}\right) \text { and } \Gamma \stackrel{\text { def }}{=} \frac{\partial^{2} E(t)}{\partial A(t)^{2}}=\frac{\Phi\left(d_{1}\right)}{A(t) \sigma \sqrt{T-t}}
$$


46. In this analysis, the Merton model is refined without altering the analytical form by means of the closed-form Gram-Charlier model of Backus and others (2004), which allows for kurtosis and skewness in returns and does not require market option prices to implement, but is constructed using the same diffusion process for asset prices. ${ }^{14}$ The above option pricing method, however, does not incorporate skewness and kurtosis, which can account for implied volatility smiles of equity prices. Thus, the Merton model is enhanced - without altering the analytical form by means of a jump diffusion that follows a standard Poisson process, where $\lambda$ is the average number of jumps per unit time. The jump size follows a log-normal distribution with average jump size $m$ and the volatility $v$ of the jump size. ${ }^{15}$ Hence, the price of a European put option can be written as

$$
P_{E}(t)=\sum_{k=0}^{\infty} \frac{\exp (-m \lambda t)(m \lambda t)^{k}}{k !} B e^{-r(T-t)} \Phi\left(-d_{2}\right)-A(t) \Phi\left(-d_{1}\right)
$$

with distance to default (DD) $d_{1}=\left(\ln (A(t) / B)+\left(r_{A}+\sigma_{A}^{2} / 2\right)(T-t)\right) / \sigma \sqrt{T-t}$ and $d_{2}=d_{1}-\sigma_{A} \sqrt{T-t} \cdot{ }^{16}$ The $k^{\text {th }}$ term in this series corresponds to the scenario where $k$ jumps occur over a 120-day rolling window. Asset volatility $\sigma_{A_{k}}=\sqrt{\sigma_{A}^{2}+k v^{2} / t}$ and the revised risk-free interest rate $r_{k}=r-\lambda(m-1)+k \ln (m) / t$ are updated accordingly.

47. Since the Merton model also contains empirical irregularities that can influence the estimation of implied assets (which also affects the calibration of implied asset volatility), the SPD of implied asset values is estimated from equity option prices without any assumptions on the underlying diffusion process (Box 1 below). Using

\footnotetext{
${ }^{14}$ Further refinements of this model would include various simulation approaches at the expense of losing analytical tractability. The ad hoc model of Dumas, Fleming, and Whaley (1998) is designed to accommodate the implied volatility smile and is easy to implement, but requires a large number of market option prices. The pricing models by Heston (1993) and Heston and Nandi (2000) allow for stochastic volatility, but the parameters driving these models can be difficult to estimate. Many other models have been proposed, to incorporate stochastic volatility, jumps, and stochastic interest rates. Bakshi and others (1997), however, suggest that most of the improvement in pricing comes from introducing stochastic volatility. Introducing jumps in asset prices leads to small improvements in the accuracy of option prices. Other option pricing models include those based on copulas, Levy processes, neural networks, GARCH models, and non-parametric methods. Finally, the binomial tree proposed by Cox, Ross and Rubinstein (1979) spurned the development of lattices, which are discrete-time models that can be used to price any type of option-European or American, plain-vanilla or exotic.

${ }^{15}$ All parameters are calibrated over the entire sample period of five years.

${ }^{16}$ The advantage of the GC model is that it is only slightly more complicated to implement than the Merton model because only two additional parameters - skewness and kurtosis - need to be estimated. The disadvantage is that it is assumes that these parameters are constant.
} 
equity option prices, we can derive the risk-neutral probability distribution of the underlying asset price at the maturity date of the options. We determine the implied asset value as the expectation over the empirical SPD by adapting the Breeden and Litzenberger (1978) method, together with a semi-parametric specification of the Black-Scholes option pricing formula (Aït-Sahalia and Lo, 1998). More specifically, this approach uses the second derivative of the call pricing function (on European options) with respect to the strike price (rather than option prices as identifying conditions). Estimates are based on option contracts with identical time to maturity, assuming a continuum of strike prices. Since available strike prices are always discretely spaced on a finite range around the actual price of the underlying asset, interpolation of the call pricing function inside this range and extrapolation outside this range are performed by means nonparametric (local polynomial) regression of the implied volatility surface (Rookley, 1997).

\section{The implied asset value is estimated directly from option prices (in tandem with} an option pricing approach that takes into account higher moments of the underlying asset diffusion process). This avoids the calibration error of using two-equations-two unknowns in the traditional Merton model in solving both implied asset value and asset volatility simultaneously. Thus, asset volatility can be derived from:

$$
\sqrt{\sigma_{A}{ }^{2}+k v^{2} / t}=\frac{E(t)}{A(t) \Phi\left(d_{1}\right)} \sigma_{E} \cdot{ }^{17}
$$

\section{Appendix Box 1. Estimation of the Empirical SPD}

Breeden and Litzenberger (1978) show Arrow-Debreu prices can be replicated via the concept of the butterfly spread on European call options. This spread entails selling two call options at strike price $K$ and buying two call options with adjacent strike prices $K^{-}=K-\Delta K$ and $K^{+}=K+\Delta K$ respectively, with the stepsize $\Delta K$ between the two call strikes. If the terminal underlying asset value $A(T)=K$ then the payoff $Z($.$) of$ $1 / \Delta K$ of such butterfly spreads at time $T-\tau$ (and time to maturity $\tau$ ) is defined as

$$
Z(A(T), K ; \Delta K)=\left.\operatorname{Price}(A(T-\tau), \tau, K ; \Delta K)\right|_{\tau=0}=\left.\frac{u_{1}-u_{2}}{\Delta K}\right|_{A(T)=K, \tau=0}=1
$$

with

$$
u_{1}=C(A(T-\tau), \tau, K+\Delta K)-C(A(T-\tau), \tau, K)
$$

\footnotetext{
${ }^{17}$ The two-equations-two-unknowns approach is based on Jones and others (1984), which was subsequently extended by Ronn and Verma (1986) to a single equation to solve two simultaneous equations for asset value and volatility as two unknowns. Duan (1994), however, shows that the volatility relationship between implied assets and equity is redundant if equity volatility is stochastic. An alternative estimation technique for asset volatility introduces a maximum likelihood approach (Ericsson and Reneby, 2004 and 2005) which generates good prediction results.
} 
and

$$
u_{2}=C(A(T-\tau), \tau, K)-C(A(T-\tau), \tau, K-\Delta K) .
$$

$C(A, \tau, K)$ denotes the price of a European call option with an underlying asset price $A$, a time to maturity $\tau$ and a strike price $K$. As $\Delta K \rightarrow 0$, Price $(A(T-\tau), \tau, K ; \Delta K)$ of the position value of the butterfly spread becomes an Arrow-Debreu security paying 1 if $A(T)=K$ and zero in other states. If $A(T) \in \square^{+}$is continuous, however, we obtain a security price

$$
\left.\lim _{\Delta K \rightarrow 0}\left(\frac{\operatorname{Price}(A(t), \tau, K ; \Delta K)}{\Delta K}\right)\right|_{K=A(T)}=f^{*}(A(T)) e^{-r_{t, \tau}}
$$

where $r_{t, \tau}$ and $f^{*}($.$) denote the risk-free interest rate and the risk-neutral probability density function (or$ SPD) at time $t$. On a continuum of states $K$ at infinitely small $\Delta K$ a complete state pricing function can be defined. Moreover, as $\Delta K \rightarrow 0$, this price

$$
\lim _{\Delta K \rightarrow 0}\left(\frac{\operatorname{Price}(A(t), \tau, K ; \Delta K)}{\Delta K}\right)=\lim _{\Delta K \rightarrow 0} \frac{u_{1}-u_{2}}{(\Delta K)^{2}}=\frac{\partial^{2} C_{t}(.)}{\partial K^{2}}
$$

will tend to the second derivative of the call pricing function with respect to the strike price evaluated at $K$, provided that $C($.$) is twice differentiable. Thus, we can write$

$$
\left.\frac{\partial^{2} C_{t}(.)}{\partial K^{2}}\right|_{K=A(T)}=f_{t}^{*}(A(T)) e^{-r_{t, \tau} \tau}
$$

across all states, which yields the SPD

$$
f_{t}^{*}(A(T))=\left.e^{-r_{t, \tau} \tau} \frac{\partial^{2} C_{t}(.)}{\partial K^{2}}\right|_{K=A(T)}
$$

under no-arbitrage conditions and without assumptions on the underlying asset dynamics. Preferences are not restricted since no-arbitrage conditions only assume risk-neutrality with respect to the underlying asset. The only requirements for this method are that markets are perfect, i.e., there are no transactions costs or restrictions on sales, and agents are able to borrow at the risk-free interest rate. 


\section{Appendix V. The Systemic CCA Methodology: Calculating the Systemic Worst-CaSe Scenario Using Multivariate Extreme Value Distribution}

49. The Systemic CCA framework is predicated on the quantification of the systemic financial sector risk (Gray and Jobst, 2010; Gray and Jobst, forthcoming). It is applied in this context to generate a multivariate extreme value distribution (MGEV) that formally captures the potential of tail realizations of market-implied joint potential losses. The analysis of dependence is completed independently from the analysis of marginal distributions, and, thus, differs from the classical approach, where multivariate analysis is performed jointly for marginal distributions and their dependence structure by considering the complete variance-covariance matrix, such as the MGARCH approach.

\section{We first define a non-parametric dependence function of individual potential}

losses. We then combine this dependence measure with the marginal distributions of these individual potential losses, which are assumed to be generalized extreme value (GEV). These marginal distributions estimated via the Linear Ratio of Spacings (LRS) method, which identifies possible limiting laws of asymptotic tail behavior of normalized extremes (Coles and others, 1999; Poon and others, 2003; Stephenson, 2003; Jobst, 2007). The dependence function is estimated iteratively on a unit simplex that optimizes the coincidence of multiple series of cross-classified random variables - similar to a Chi-statistic that measures the statistical likelihood of observed values to differ from their expected distribution. More specifically, we first specify the asymptotic tail behavior of the vector-valued series $\mathbf{X}_{i, j} \equiv \mathbf{P}_{i, j}=\left(P_{1}^{n}, \ldots, P_{m}^{n}\right)$ of potential losses (i.e., put option values) of an $m$ number of financial sector entities $j$ as the limiting law of an $n$-sequence of normalized maxima (over rolling window estimation period of $\tau=120$ days and daily updating), so that the $j^{\text {th }}$ univariate marginal

$$
\left.y_{j}=y_{j}(x)=\left(1+\xi_{j}\left(x-\mu_{j}\right) / \sigma_{j}\right)_{+}^{-1 / \xi_{j}} \text { (for } j=1, \ldots, m\right)
$$

lies in the domain of attraction of the generalized extreme value (GEV) distribution, where $1+\xi_{j}\left(x-\mu_{j}\right) / \sigma_{j}>0$, scale parameter $\sigma_{j}>0$, location parameter $\mu_{j}$, and shape parameter $\xi_{j}$. The higher the absolute value of shape parameter, the larger the weight of the tail and the slower the speed at which the tail approaches its limit.

51. Second, the multivariate dependence structure of joint tail risk of potential losses is derived non-parametrically as the convex function:

$$
A(\omega)=\min \left(1, \max \left\{n\left\{\sum_{i=1}^{n} \bigwedge_{j=1}^{m} \frac{y_{i, j} / \hat{y}_{\bullet_{j}}}{\omega_{j}}\right\}^{-1}, \omega, 1-\omega\right\}\right)
$$


over the same estimation window, where $\hat{y}_{\bullet j}=\sum_{k=1}^{n} y_{i, j} / n$ and $0 \leq \max \left(\omega_{1}, \ldots, \omega_{m-1}\right) \leq A\left(\omega_{j}\right) \leq 1$ for all $0 \leq \omega_{j} \leq 1$, subject to the optimization of the (m-1)dimensional unit simplex $S_{m}=\left\{\left(\omega_{1}, \ldots, \omega_{m-1}\right) \in \square_{+}^{n}: \omega_{j} \geq 0,1 \leq j \leq m-1 ; \sum_{j=1}^{m-1} \omega_{j} \leq 1\right.$ and $\left.\omega_{m}=1-\sum_{j=1}^{m-1} \omega_{j}\right\}$.

52. Finally, after estimation of the marginal distributions and the dependence structure over the a rolling window of $\tau$ number of days, we obtain the multivariate distribution:

$$
G_{t, \hat{\xi}, \hat{\mu}, \hat{\sigma}}(x)=\exp \left\{-\left(\sum_{j=1}^{m} y_{j}\right) A(\omega)\right\}
$$

at time $t=\tau+1$, using the maximum likelihood estimation $\hat{\theta}_{M L E}=\underset{\theta}{\arg \max } \prod_{i=1}^{n} g(x ; \theta)$.

53. We then obtain the Expected Shortfall (ES) (or conditional Value-at-Risk (VaR)) as the probability-weighted residual density beyond a pre-specified statistical confidence level (say, $a=0.95$ ) of maximum losses, where point estimate of joint potential losses is defined as: ${ }^{18}$

$$
\hat{x}_{t, a}=G_{t, \hat{\xi}, \hat{\mu}, \hat{\sigma}}^{-1}(a)=\hat{\mu}_{j}+\hat{\sigma}_{j} / \hat{\xi}_{j}\left(\left(-\frac{\ln (a)}{A(\omega)}\right)^{-\hat{\xi}_{j}}-1\right) .
$$

ES defines the average estimated value $z$ of the aggregate potential losses over estimation days $\tau$ in excess of the statistical confidence limit. Thus, we can write ES at time $t$ as

$$
E S_{t, \tau, a}=-\mathrm{E}\left[z_{\tau} \mid z_{\tau} \geq G_{t}^{-1}(a)=V a \mathrm{R}_{t, a}\right]
$$

at a threshold quantile value

$$
V a \mathrm{R}_{t, \tau, a}=\sup \left\{G_{t}^{-1}(\bullet) \mid \operatorname{Pr}\left[\approx \tau>G_{t}^{-1}(\bullet)\right] \geq a=0.95\right\} .
$$

\footnotetext{
${ }^{18}$ Expected shortfall (ES) is an improvement over $\mathrm{VaR}$, which, in addition to being a pure frequency measure, is "incoherent", i.e., it violates several axioms of convexity, homogeneity, and sub-additivity found in coherent risk measures. For example, sub-additivity, which is a mathematical way to say that diversification leads to less risk, is not satisfied by VaR.
} 
ES can also be written as a linear combination of individual ES values, where the relative weights (in the weighted sum) are given by the second order cross-partial derivatives of the inverse of the joint probability density function $G_{t}^{-1}(a)$ to changes in both the dependence function and the individual marginal severity of expected loses. Thus, by re-writing $E S_{t, \tau, a}$ above, we obtain the sample ES

$$
E S_{t, \tau, a}=-\sum_{j}^{m} M C_{j, \tau, a} \mathrm{E}\left[z_{j, \tau} \mid q_{m, \tau} \geq G_{t}^{-1}(a)=V a \mathrm{R}_{t, q_{a}}\right],
$$

where the relative weight of institution $j$ is defined as the marginal contribution

$$
M C_{j, \tau, a}=\frac{\partial^{2} G_{t}^{-1}(a)}{\partial y_{j, a} \partial A^{-1}(\omega)} \text { s.t. } \sum_{i}^{m} M C_{j, \tau, a}=1 \text { and } M C_{j, \tau, a} \chi_{i, \tau} \leq z_{m, \tau}
$$

to expected shortfall

$$
E S_{t, \ell, a}=-\sum_{j}^{m} \psi_{j, \ell, a} \mathrm{E}\left[z_{j, \ell} \mid q_{m, \ell} \geq G_{t}^{-1}(a)=V a R_{t, q_{a}}\right]
$$

attributable to the joint effect of both the marginal distribution $y_{j, a}$ and the change of the dependence function $A($.$) absent institution j$. 


\section{REFERENCES}

Acharya, V. V., L. Pedersen, T. Philippon and M. Richardson, 2009, "Regulating Systemic Risk," in: V. V. Acharya and M. Richardson (eds.). Restoring Financial Stability: How to Repair a Failed System (New York: Wiley).

Adrian, T. and M. K. Brunnermeier, 2008, “CoVaR,” FRBNY Staff Reports 348 (New York: Federal Reserve Bank of New York).

Aikman, D., P. Alessandri, B. Eklund, P. Gai, S. Kapadia, E. Martin, N. Mora, G. Sterne, Gabriel and M. Willison, 2009, "Funding Liquidity Risk in a Quantitative Model of Systemic Stability,” Working Paper No. 372 (London: Bank of England).

Aït-Sahalia, Y. and A. W. Lo, 1998, "Nonparametric Estimation of State-Price Densities Implicit in Financial Asset Prices, Journal of Finance, Vol. 53, pp. 499-547.

Alessandri, P., P. Gai, S. Kapadia, N. Mora and C. Puhr, 2009, "Towards a Framework for Quantifying Systemic Stability," International Journal of Central Banking, Vol. 5, No. 3, pp. 47-81.

Alessandri, P. and M. Drehmann, 2010, "An Economic Capital Model Integrating Credit and Interest Rate Risk in the Banking Book," Journal of Banking and Finance, Vol. 34, No. 4, pp. 730-42.

Backus, D. K., S. Foresi and L. Wu, 2004, “Accounting for Biases in Black-Scholes," Working Paper, New York University, Goldman Sachs Group, and Baruch College.

Bakshi, G., C. Cao, and Z. Chen, 1997, "Empirical Performance of Alternative Option Pricing Models," Journal of Finance, Vol. 52, No. 5, pp. 2003-49.

Basel Committee on Banking Supervision (BCBS), 2006, "Basel II: International Convergence of Capital Measurement and Capital Standards: A Revised Framework Comprehensive Version," June (available at http://www.bis.org/publ/bcbs128.htm).

Basel Committee on Banking Supervision (BCBS), 2010a, "Basel III: A Global Regulatory Framework for More Resilient Banks and Banking System," December.

Basel Committee on Banking Supervision (BCBS), 2010b, "Results of the Comprehensive Quantitative Impact Study,” BCBS Publication No. 186 (December).

Basel Committee on Banking Supervision (BCBS), 2010c, "Basel III: International Framework for Liquidity Risk Measurement, Standards and Monitoring,” December. 
Black, F. and J. C. Cox, 1976, "Valuing Corporate Securities: Some Effects on Bond Indenture Provisions," Journal of Finance, Vol. 31, pp. 351-368.

Black F. and M. Scholes, 1973, "The Pricing of Options and Corporate Liabilities," Journal of Political Economy, Vol. 81, No. 3, pp. 637-54.

Collin-Dufresne, P. and R. S. Goldstein, 2001, "Do Credit Spreads Reflect Stationary Leverage Ratios?," Journal of Finance, Vol. 56, pp. 1929-57.

Committee of European Banking Supervisors (CEBS), 2010, "Results of the Quantitative Impact Study," December 16.

Cox, J. C., Ross, S. A. and M. Rubinstein, 1979, "Option Pricing: A Simplified Approach," Journal of Financial Economics, Vol. 7, No. 3, pp. 229-63.

Deutsche Bundesbank, 2010, Financial Stability Review 2010, November.

Drehmann M., Sorensen S. and M. Stringa, 2010, “The Integrated Impact of Credit and Interest Rate Risk on Banks: A Dynamic Framework and Stress Testing Application" Journal of Banking and Finance, Vol. 34, No. 4, pp. 713-729.

Duan, J. C., 1994, "Maximum Likelihood Estimation Using Price Data of the Derivative Contract," Mathematical Finance, Vol. 4, No. 2, pp. 155-67.

Dumas, D., J. Fleming and R. E. Whaley, 1998, "Implied Volatility Functions: Empirical Tests," Journal of Finance, Vol. 53, No. 6, pp. 2059-106.

Ericsson, J., and J. Reneby, 2005, “Estimating Structural Bond Pricing Models," Journal of Business, Vol. 78, No. 2, pp. 707-35.

Ericsson, J., and J. Reneby, 2004, "An Empirical Study of Structural Credit Risk Models Using Stock and Bond Prices,” Journal of Fixed Income, Vol. 13, No. 4, pp. 38-49.

European Central Bank, 2005, "Consolidation and Diversification in the Euro Area Banking Sector,” Monthly Bulletin (May), pp. 79-87.

Gray, D. F. and A. A. Jobst, 2009, "Higher Moments and Multivariate Dependence of Implied Volatilities from Equity Options as Measures of Systemic Risk," Global Financial Stability Report, Chapter 3, April (Washington: International Monetary Fund), pp. 128-131.

, 2010a, "New Directions in Financial Sector and Sovereign Risk Management," Journal of Investment Management, Vol. 8, No.1, pp.23-38. 
,2010b, "Risk Transmission Between Sovereigns and Banks in Europe," Global Financial Stability Report, Chapter 1, October (Washington: International Monetary Fund), pp. 12 and 40-44.

, forthcoming, "Systemic Contingent Claims Analysis (Systemic CCA) - Estimating Potential Losses and Implicit Government Guarantees to Banks," IMF Working Paper (Washington: International Monetary Fund).

Gray, D. F., Jobst, A. A. and S. Malone, 2010, "Quantifying Systemic Risk and Reconceptualizing the Role of Finance for Economic Growth," Journal of Investment Management, Vol. 8, No.2, pp. 90-110.

Heston, S. L., 1993, "A Closed-Form Solution for Options with Stochastic Volatility with Applications to Bond and Currency Options," Review of Financial Studies, Vol. 6, No. 2, pp. 327-43.

Heston, S. L. and S. Nandi, 2000, "A Closed-Form GARCH Option Valuation Model," Review of Financial Studies, Vol. 13, No. 3, pp. 585-625.

Huang, X., H. Zhou and H. Zhu, 2010, "Assessing the Systemic Risk of a Heterogeneous Portfolio of Banks during the Recent Financial Crisis," Working paper (January 26), $22^{\text {nd }}$ Australasian Finance and Banking Conference 2009 (available at http://ssrn.com/abstract=1459946).

International Monetary Fund (IMF), 2011. Global Financial Stability Report, Chapter 2 (April) (Washington: International Monetary Fund).

Jobst, A. A., forthcoming, "Measuring Systemic Risk-adjusted Liquidity (SRL)," IMF Working Paper (Washington: International Monetary Fund).

Jobst, A. A., 2007, "Operational Risk - The Sting is Still in the Tail But the Poison Depends on the Dose," Journal of Operational Risk, Vol. 2, No. 2 (Summer), pp. 1-56. Also published as IMF Working Paper No. 07/239 (October).

Jobst, A. A. and H. Kamil, 2008, "Stock Market Linkages Between Latin America and the United States During 'Tail Events'," in Latin American Linkages to Global Financial Market Turbulence, Regional Economic Outlook (Washington: Western Hemisphere Department, International Monetary Fund), pp. 35-36.

Jones, E. P., S. P. Mason and E. Rosenfeld, 1984, "Contingent Claims Analysis of Corporate Capital Structures: An Empirical Investigation,” Journal of Finance, Vol. 39, No. 3, pp. 611-25. 
Longstaff, F. A. and E. S. Schwartz, 1995, "A Simple Approach to Valuing Risky Fixed and Floating Rate Debt," Journal of Finance, Vol. 50, pp. 789-819.

Lyden, S. and D. Saraniti, 2000, "An Empirical Examination of the Classical Theory of Corporate Security Valuation,” Working Paper, Barclays Global Investors.

Merton, R. C., 1973, “Theory of Rational Option Pricing," Bell Journal of Economics and Management Science, Vol. 4 (Spring), pp. 141-83.

Ogden, J. P., 1987, "Determinants of the Ratings and Yields on Corporate Bonds: Tests of the Contingent Claims Model," Journal of Financial Research, Vol. 10, No. 4, pp. 329-39.

Ronn, E. I, and A. K. Verma, 1986, "Pricing Risk-Adjusted Deposit Insurance: An OptionBased Model,” Journal of Finance, Vol. 41, No. 4, pp. 871-95.

Rookley, C., 1997, "Fully Exploiting the Information Content of Intra Day Option Quotes: Applications in Option Pricing and Risk Management," mimeo, University of Arizona. 


\section{ATTACHMENT. GUIDELINES FOR THE U.K. FSAP UPDATE BOTTOM-UP SOLVENCY STRESS TESTS BY BANKS}




\section{INTERNATIONAL MONETARY FUND (IMF) \\ Monetary and Capital Markets Department (MCM)}

\section{United Kingdom Financial Stability Assessment Program (FSAP) Update 2011 Guidelines for Solvency Stress Test ${ }^{19}$}

Date: April 2, 2011

\section{Contents}

I. Introduction $\underline{92}$

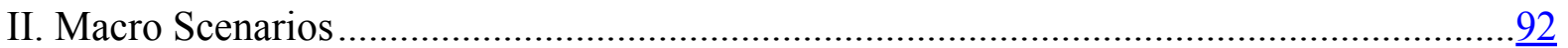

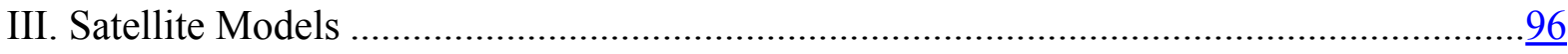

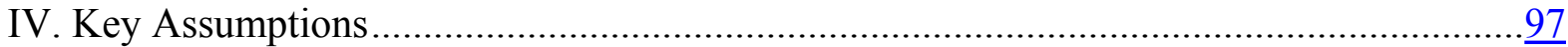

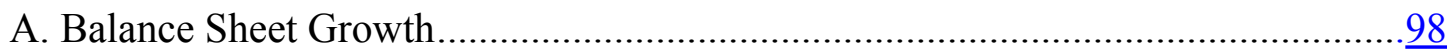

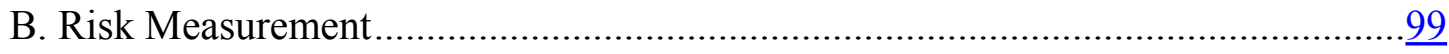

C. Dividend Payout Rule/Retained Income …………….........................................99

D. Additional Elements Impacting Profits and Losses .............................................101

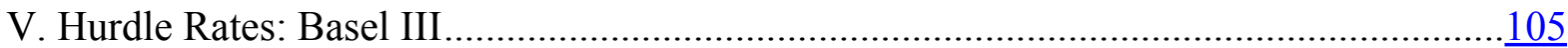

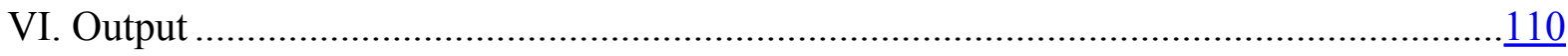

Appendix I. Summary of Scenarios, Key Assumptions and Hurdle Rates.............................111

Appendix II. Other Macroeconomic Variables................................................................

Appendix III: Alternative Funding Risk Models ……...................................................117

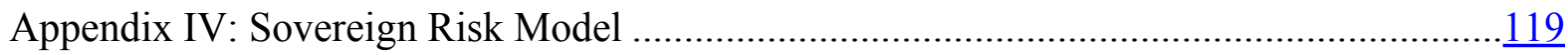

Appendix V. Solvency Stress Tests: Desired Output …………..........................................

Appendix VI. Proposed Timeline for Completion of Solvency Stress Test...........................125

${ }^{19}$ Prepared by Andy Jobst (IMF/MCM). 


\section{INTRODUCTION}

1. This note summarizes key assumptions related to the calibration and estimation of the bottom-up, system-wide solvency stress testing component of the IMF's United Kingdom FSAP Update. It contains specific instructions regarding the implementation of such a stress test using end-2010 data.

\section{The objective of this stress test, as part of the FSAP mission's analysis of} financial stability, is to assess the capital adequacy of the banking sector under different macroeconomic scenarios. It is anticipated that this exercise will contribute to a more comprehensive understanding of the U.K. financial system's general vulnerabilities to shocks without identifying individual institutions. The stress test will incorporate specific risk factors, including cross-border developments (particularly sovereign risk), funding risks, upcoming regulatory reforms, as well as the behavioral changes of banks.

3. Thus, the focus and consequences of the stress test differs from that of other stress testing exercises in which U.K. banks have involved. In particular, the recent European effort coordinated by the Committee of European Banking Supervisors (CEBS) and the forthcoming one by the European Banking Authority (EBA) jointly with European Central Bank (ECB), are aimed at analyzing inherent risks in the near term and to assess potential capital needs of specific institutions, from which management actions may be required. In contrast, no management action would be expected as a result of the FSAP stress tests.

4. A summary of the macro scenarios, key assumptions and hurdle rates is presented in Appendix $\mathbf{I}$.

5. Firms are requested to conduct their bottom-up stress tests, using end-2010 data, and to report their results to the Financial Services Authority (FSA) by Wednesday, May 4, 2011. The FSA will perform due diligence analysis and report aggregate findings to the IMF FSAP team.

\section{Macro Scenarios}

6. The FSAP will examine three adverse macro scenarios based on the deviation of GDP projections from the central growth forecast - the IMF's World Economic Outlook (WEO) baseline projection of real GDP growth (Table 1). In portraying the stress scenarios as a "mark-up" over the most likely outcome, one can take into account perceived risk, i.e., the potential for central expectations to vary due to uncertainties as well as revisions in light of new information. 
Table 1. Overview of Macroeconomic Scenarios

(In percent)

\begin{tabular}{|c|c|c|c|c|c|}
\hline & 2011 & 2012 & 2013 & 2014 & 2015 \\
\hline & \multicolumn{5}{|c|}{ Real GDP growth (y-o-y) } \\
\hline WEO baseline & 2.15 & 1.98 & 1.91 & 2.44 & 2.55 \\
\hline "Double Dip" Recession Scenario (mild) & -0.73 & 0.90 & 2.43 & 2.50 & 2.58 \\
\hline "Double Dip" Recession Scenario (severe) & -0.24 & -2.61 & 0.23 & 2.58 & 2.62 \\
\hline \multirow[t]{2}{*}{ "Slow Growth" Scenario } & 1.26 & 0.44 & 0.51 & 1.03 & 1.09 \\
\hline & \multicolumn{5}{|c|}{ Short-term interest rate (3-month LIBOR) } \\
\hline WEO baseline & 0.98 & 1.64 & 2.32 & 2.70 & 2.70 \\
\hline "Double Dip" Recession Scenario (mild) & 1.96 & 3.14 & 2.88 & 2.72 & 2.71 \\
\hline "Double Dip" Recession Scenario (severe) & 1.05 & 1.65 & 2.05 & 2.38 & 2.57 \\
\hline \multirow[t]{2}{*}{ "Slow Growth" Scenario } & 0.95 & 1.51 & 2.23 & 2.55 & 2.65 \\
\hline & \multicolumn{5}{|c|}{ Long-term interest rate (10 years) } \\
\hline WEO baseline & 3.54 & 3.83 & 4.35 & 4.62 & 4.83 \\
\hline "Double Dip" Recession Scenario (mild) & 3.80 & 4.09 & 4.00 & 4.00 & 4.00 \\
\hline "Double Dip" Recession Scenario (severe) & 3.38 & 3.28 & 3.37 & 3.59 & 3.80 \\
\hline \multirow[t]{2}{*}{ "Slow Growth" Scenario } & 3.37 & 3.27 & 3.19 & 3.14 & 3.07 \\
\hline & \multicolumn{5}{|c|}{ Unemployment rate } \\
\hline WEO baseline & 7.39 & 6.55 & 5.87 & 5.28 & 5.08 \\
\hline "Double Dip" Recession Scenario (mild) & 9.00 & 10.58 & 8.72 & 6.80 & 5.82 \\
\hline "Double Dip" Recession Scenario (severe) & 9.08 & 11.23 & 11.89 & 9.80 & 8.20 \\
\hline \multirow[t]{2}{*}{ "Slow Growth" Scenario } & 7.39 & 7.03 & 7.20 & 7.26 & 7.18 \\
\hline & \multicolumn{5}{|c|}{ Inflation rate $(\mathrm{CPI})$} \\
\hline WEO baseline & 2.60 & 1.99 & 2.01 & 2.01 & 2.16 \\
\hline "Double Dip" Recession Scenario (mild) & 2.39 & 0.18 & 1.01 & 2.01 & 2.16 \\
\hline "Double Dip" Recession Scenario (severe) & 3.78 & 4.01 & 3.38 & 2.50 & 2.16 \\
\hline "Slow Growth" Scenario & 3.61 & 3.34 & 2.36 & 2.05 & 1.88 \\
\hline
\end{tabular}

7. In line with the system-wide supervisory stress test conducted by the FSA, the FSAP also considers two additional adverse scenarios that amplify the adversity of stress in terms of severity and duration. These adverse scenarios comprise:

- "Double dip recession" scenarios (mild/severe and short-term), namely,

$>$ one standard deviation of real GDP growth (based on the volatility of the twoyear growth rate between 1980 and 2010) from the baseline growth trend over a five-year horizon (with positive adjustment dynamics during the subsequent three years), in which a shock to economic growth results in a sharp decline of output and rising employment over two years; and 
two standard deviations of the same.

- A "slow growth" scenario (severe and long-term) with a cumulative negative deviation of about 7.3 percentage points in real GDP, or an average annual growth rate of about 0.9 percent over a five-year horizon, as a result of a permanent shock to productive capacity amid rising inflation expectations.

\section{The macro scenarios are in line with the spectrum of economic shocks} considered in the context of other stress testing exercises (Figure 1):

- $\quad$ The stress tests completed by the CEBS, the FSA, as well as the FSAP have in common a "double dip"-like adverse scenario.

- The mild and severe "double dip" scenarios are consistent with the adverse scenarios of the stress test conducted by the EBA for 2011 (over the first two years) and the new "anchor scenario" of the FSA's, respectively.

- $\quad$ The prolonged slow growth scenario remains unique to the FSAP stress testing exercise, and is considered the "tail shock" scenario.

- $\quad$ The other macro variables used for the stress test (short-term interest rate represented by the 3-month LIBOR; the long-term interest rate represented by the 10 -year Treasury bond yield; unemployment and headline CPI inflation) are determined using the U.K. authorities' macro models.

9. The adverse scenarios are underpinned by the following possible narratives:

- $\quad$ For the "double dip" scenario, useful approach would be to simulate a semipermanent commodity price shock (e.g., oil price), a large shock to foreign demand, and possibly, a small endogenous shock to the uncovered interest rate parity governing the sterling-dollar exchange rate (i.e. a risk premium). This shock can be interpreted as a shift of investors away from dollar assets towards sterling assets, thereby aggravating the appreciation of the sterling and leading at least to a small output loss in the United Kingdom in the short-term.

- For the "slow growth" scenario, a useful approach would be to simulate a negative global shock to technical progress. As this is a negative supply shock and price pressures do not abate, short-term interest rates are not lower after the shock. This might prevent otherwise lower short-term interest rates if one were to assume temporary shocks to labor participation or a slowdown of productivity. By keeping consumption and saving endogenous there is no shock variable for the saving rate. Increasing savings by introducing a negative demand shock (via consumption) would otherwise be countered by lower policy rates. 
Figure 1. Overview of Macroeconomic Scenarios: GDP Growth

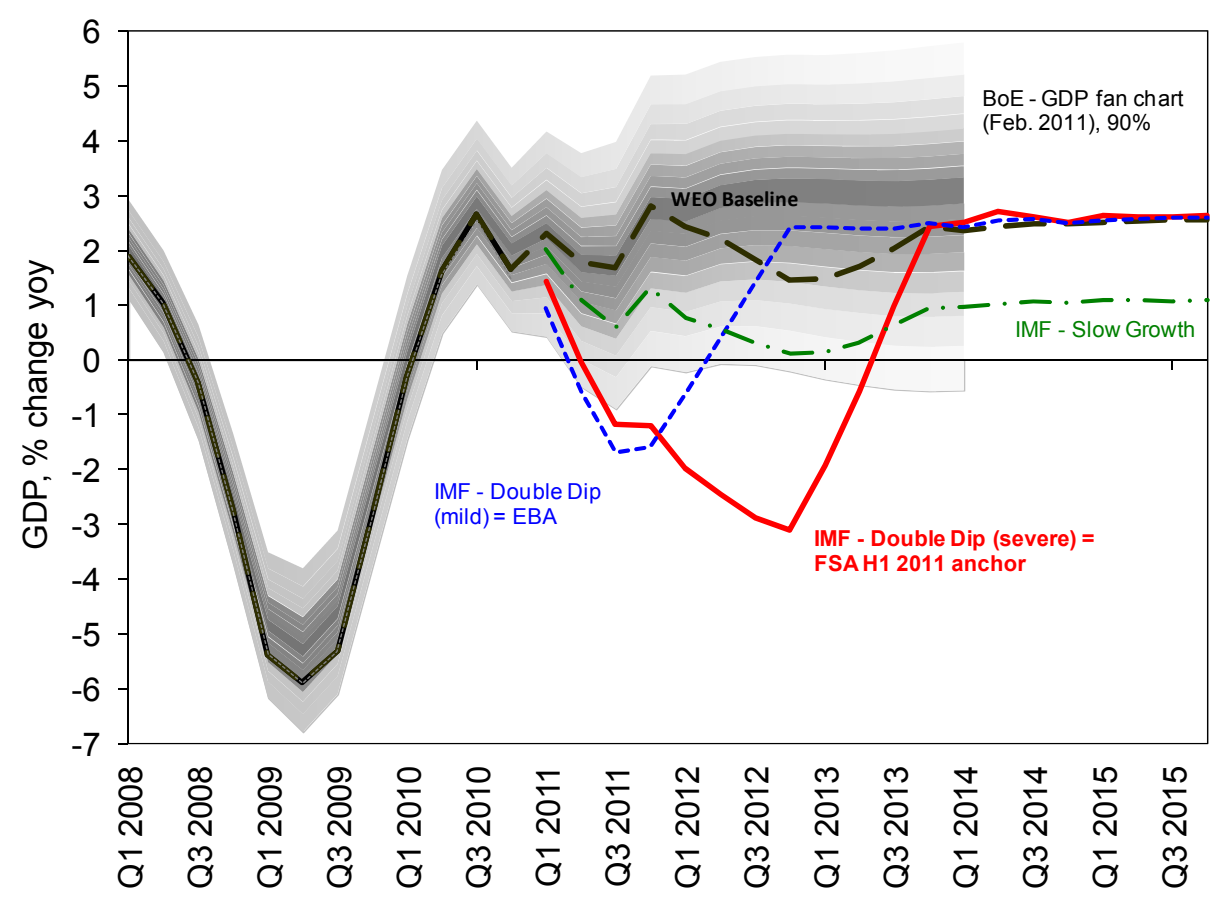

10. Cross-border effects are considered in all macro scenarios. Assumptions about the type of shocks (temporary or permanent), and the degree to which they affect relevant countries have to be aligned: ${ }^{20}$

- $\quad$ The WEO baseline GDP growth rates are applied to all countries affecting the macro projections and the macro-financial linkages of banks with significant footprints in other parts of the world, financial sector performance.

- In absence of a Fund-imposed macro model for the adverse scenario of multiple countries, the simulated estimates from the IMF's Growth Projection Model (GPM) should be used as a guide for a bank's individual country projections.

- $\quad$ The GPM simulates the spillover of a hypothetical EU shock to the other regions in the world, in terms of growth, inflation and interest rates (Appendix II). Additionally, a uniform change in the short- and long-term interest rates in both the euro area and the United States is provided. Firms are requested to scale the interest rate shock to the magnitude of changes in nominal GDP.

- Conditioning on these effects should result in findings that are similar to the ones obtained under the adverse scenario in the CEBS/EBA stress tests, where spillover

\footnotetext{
${ }^{20}$ One recent example where this was attempted is the CEBS stress testing exercise.
} 
shocks from EU countries to the rest of the world are examined in a mild adverse scenario. $^{21}$

\section{SATEllite Models}

\section{Satellite models should be used to specify the macro-financial linkages of firm} performance over the forecast horizon. Firms are required to determine credit losses and various elements of profit, including funding costs in response to changing capitalization via so-called "satellite models" or expert judgment. When expert-judgment is used, it should be closely aligned with the output of satellite models. ${ }^{22}$ For satellite models should at least cover the last five years and include a lagged term, GDP growth, interest rates, other macroeconomic variables, and firm-specific variables, such as leverage, loan-to-asset ratio and the funding gap:

- $\quad$ Credit losses are forecast based on separate models for write-downs and write-ups specific to each sector (corporate, retail, public, financial institutions).

- $\quad$ Profits are estimated using separate models for interest income, ${ }^{23}$ interest expenses, net fee and commission income, and the operational expenses. Income taxes are assumed to be 25 percent for firms recording a profit and zero otherwise.

- $\quad$ Funding costs are simulated through interest expenses (see below).

- $\quad$ Trading income under stress should be aligned with GDP growth, based on historical data. ${ }^{24}$ To this end, GDP growth under each scenario and year can be matched to the corresponding GDP growth rate during the last 15 years (i.e. the growth rate closest to the simulated one). However, firms that experienced exceptionally high trading losses during the recent credit crisis (relative to the historical experience) may wish to model the probability distribution of trading income and match point estimates to the percentile level of projected GDP growth. Thus, a high-dimensional parametric fit function can be used to align GDP with trading.

\footnotetext{
${ }^{21}$ These shocks are scaled up (e.g. doubled) for the more severe "double dip recession" scenario, and spread over longer time horizon, for the "slow growth" scenario.
}

${ }^{22}$ Benchmarks for the sensitivity of credit losses to macroeconomic variables are the stress tests conducted by the European authorities (CEBS in 2010 and EBA in 2011) as well as past system-wide stress tests conducted by the FSA.

${ }^{23}$ For the large banks, a model using net interest income was referred to.

${ }^{24}$ While empirical evidence suggests that there is a very weak relation between the trading result and macroeconomic conditions, it is assumed that unfavorable trading results coincide with macroeconomic shocks - a scenario that was observed for many U.K. banks during the crisis. 
12. The stress test should allow for the impact of losses on both the trading and banking books in order to cover all material exposures (such as sovereign debt) in economic terms, irrespective of their accounting treatment, and then estimate the effects on income and expenses.

\section{As a general rule, satellite models need to be clearly documented and back-} tested. Since firms conduct their own stress test ("bottom-up"), the FSA, together with the IMF FSAP team, will require full disclosure of the various satellite models and expert judgments on earnings capacity, market and credit losses as well as the change in funding conditions under the various scenarios.

\section{Key Assumptions}

\section{This section describes the various assumptions that should be applied to the} bottom-up solvency stress test. Firms are also encouraged to conduct additional solvency stress tests without these restrictions so that the aggregate impact of business strategies and idiosyncratic assumptions can be compared and assessed. ${ }^{25}$

\section{The sample of firms involved in the IMF's solvency stress testing exercise} includes the seven largest banks: The five largest U.K.-domiciled banking groups (HSBC, Barclays, RBS, Lloyds Banking Group, Standard Chartered); the largest foreign subsidiary with significant retail operations (Santander U.K.); and the largest building society (Nationwide). The stress test covers only banking operations within the United Kingdom. Banks with other significant businesses (e.g., insurance) that are separate companies, subject to separate regulations and that are effectively ring-fenced, may exclude those businesses from the stress test.

\section{In order to measure the impact of stress in economic terms, an economic} definition of capital adequacy should be used. Since all sample banks have adopted advanced Basel II standards, their economic profile is tested by calculating IRB capital requirements. As such, it is important to account for the point-in-time level of risk-weighted assets (RWAs), as well as changes in RWAs under stress in economic terms.

17. The test includes, as a minimum, credit risk and market risk. In order to allow for meaningful results, granular data should be used. Ideally, the tests are based on probabilities of default (PDs) and losses-given-default (LGDs) on a firm and/or portfolio level. In case this

\footnotetext{
${ }^{25}$ In that context, institutions are expected to demonstrate a clear link between their risk appetite, their business strategy, and their capital planning relative to the outcome of difference macro scenarios. In particular, institutions should assess and be able to demonstrate (by credible management actions, plans and other concrete steps, including changes in business strategy, reinforcing the capital base and/or other contingency plans) their ability to remain above regulatory minimum capital requirements during a stress that is consistent with their stated risk appetite.
} 
information is not available, other proxies such as provisions, NPLs and country-level LGDs may be referenced. Besides meaningful data on credit risk, data should include sectoral credit information, information on securities in the trading and banking book, and regulatory data on capital and capital adequacy.

\section{A. Balance Sheet Growth}

\section{Firms' balance sheets are assumed to be constant and to grow in line with}

nominal GDP. The growth rate assumption will also impact the forecast of losses and profits under various satellite models, which should be demonstrated. The assumption of a constant balance sheet falls in between the two extremes of static and dynamic balance sheets used in different stress tests - the FSA supervisory stress tests assume a dynamic balance sheet, while the planned EBA stress test assumes a static balance sheet (except for pre-agreed disposals).

\section{Firms affected by stress are assumed to reduce asset growth through}

deleveraging or other means. Based on empirical evidence and expert judgment it is assumed that credit growth starts declining once firms reach a threshold of 2.5 percentage points above the minimum Tier 1 capital ratio applicable (e.g., 4.0 percent in 2011) over the forecast horizon. If a firm falls below the threshold, credit growth declines by twice the capital shortfall in percentage points. For instance, for a Tier 1 capital ratio of one percentage point below the regulatory minimum, credit growth declines by two percentage points. This adjustment is made in the same year the potential for deleveraging is assessed, and should shed light on potential deleveraging attempts by firms to cope with the capital shortfall during the same year (Figure 2).

20. Asset disposals are generally disallowed, and maturing exposures are assumed to be replaced:

- $\quad$ Asset disposals (such as books in run-off or sales of non-core businesses) and acquisitions over time should not be considered, except where agreed with legally binding commitments under EU state aid rules (and consequent private contracts, e.g., LBG and RBS asset disposals and Santander U.K. acquisitions of selected RBS branch networks), consistent with EBA stress test assumptions.

- $\quad$ Firms are also assumed to replace maturing exposures.

- Any interim capital until end-2010 can be considered in calculations.

- $\quad$ Firms in the Asset Protection Scheme (APS) should run stress tests on an APS vs. noAPS scenarios, and show the range of changes to solvency position. 
Figure 2. Credit Growth Conditional on Tier 1 Ratio (Example: Baseline scenario, year 1)

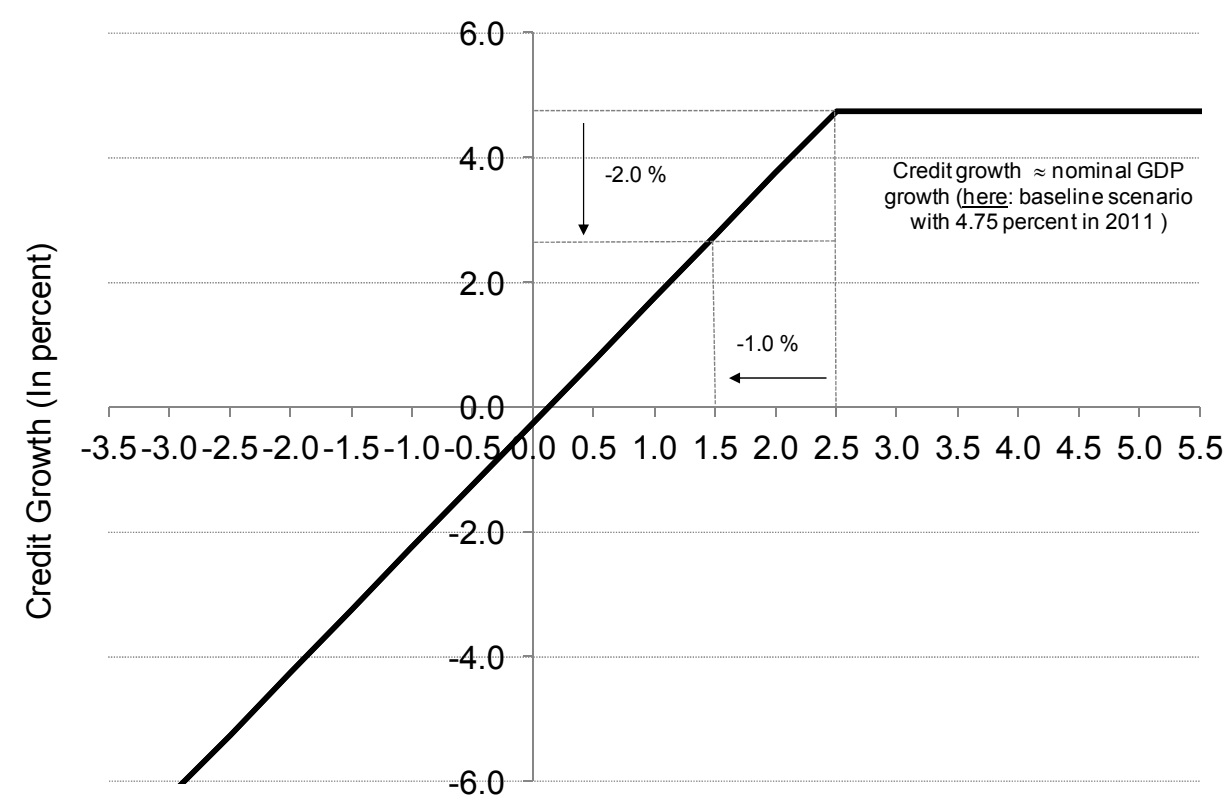

Capital Buffer above Minimum Tier 1 Capital Requirement (In percentage points)

\section{B. Risk Measurement}

21. Firms are expected to closely follow existing reporting standards, such that:

- $\quad$ Probabilities of default (PDs) and losses-given-default (LGDs) are assumed to be "through-the-cycle", but an appropriate way has to be found to run tests based on point-in-time risk parameters (such as through the scenario);

- $\quad$ no feedback effect of firms' lending on macro variables is assumed;

- there is no change in the portfolio allocation to reduce RWAs; and

- $\quad$ changes to firms' lending standards and credit balance must be in accordance with changes in credit growth experienced during the last business cycle.

\section{Dividend Payout Rule/Retained Income}

22. The assessment of potential capital shortfall is made conditional on assumptions regarding the payout of dividends:

- Dividend payouts are payable out of the previous year's profit and, thus, cannot result in a drop below any of the minimum capital requirements. 
- Well-capitalized firms (i.e., firms that meet the minimum capital requirement and generate positive earnings after taxes) are assumed to pay out dividends only if they report profits.

- $\quad$ Dividends are paid only by firms that satisfy all three measures of capital adequacy (total capital, Tier 1, and core Tier 1 capital ratios) and exhibit a leverage ratio of no less than three percent in a given year (after having created adequate provisions for impairment of assets and transfer of profits to staff benefits and statutory reserves).

23. The dividend pay-out rule is consistent with the maximum pay-out ratios defined under Basel III: ${ }^{26}$

- The dividend payout ratio is defined as the percentage of "dividend payable in a year" to "net profit during the year".

- The maximum payout is capped at 40 percent of profits, in line with empirical evidence.

- If the firm meets the minimum total capital ratio of 8.0 percent (after the envisaged dividend payout and, at the same time, exhibits sufficient Tier 1 and core Tier 1 capitalization) but falls below the 10.5 percent threshold, it is considered capitalconstrained and follows a schedule of fixed dividend payouts per Table 2, in anticipation of the full adoption of the "capital conservation buffer" of 2.5 percentage points as of January 1, 2019.

\footnotetext{
${ }^{26}$ Under Basel III, the maximum pay-out rules are defined based on core Tier 1 capitalization rather than based on total capitalization.
} 
Table 2. Payout Ratio Conditional on Capitalization under Stress (In percent)

\begin{tabular}{ccc}
\hline & \multicolumn{2}{c}{$\begin{array}{c}\text { UK FSAP Update } \\
\text { Dividend pay-out ratio } \\
\text { based on }\end{array}$} \\
\cline { 1 - 3 } $\begin{array}{c}\text { Capital buffer } \\
\text { In percentage points }\end{array}$ & $\begin{array}{c}\text { Maximum pay-out ratio } \\
\text { hotal capital } \\
\text { In percent }\end{array}$ & $\begin{array}{c}\text { Core Tier 1 capital } \\
\text { In percent }\end{array}$ \\
\cline { 1 - 3 } $0-0.5$ & 5 & 0 \\
$0.5-1$ & 10 & 20 \\
$1-1.5$ & 15 & 20 \\
$1.5-2$ & 20 & 40 \\
$2-2.5$ & 30 & 40 \\
$>2.5$ & 40 & 40 to 100 \\
\hline
\end{tabular}

D. Additional Elements Impacting Profits and Losses

\section{Funding risk}

24. The treatment of funding costs is explicit and avoids the simultaneity problem between contemporaneous losses and higher costs of capital. In each year, the impact of shocks to the firm's balance sheet on the cost of funding ("funding rates") should be estimated, and the effects on funding costs in the subsequent year are estimated (without taking into account the fact that losses themselves during the current year are attributable to higher funding costs). ${ }^{27}$

25. The estimation of the annual increase of funding costs is unaffected by possible balance sheet deleveraging:

- Each year, funding costs are estimated - all short-term debt is funded at the new funding rate, but only the long-term debt due in each year is re-priced at the new rate. Based on this information, the change in the overall funding cost relative to the sample end-date (end-2010) can be derived. The short-term rate rises in proportion of the increase in long-term rate.

\footnotetext{
${ }^{27}$ The macro-scenarios affect any liquidity stress test only insofar as any changes in funding costs will be consistent with assumptions applied to the solvency test.
} 
- Against the background of rising competition for stable funding under adverse scenarios, the deposit rate moves in proportion to the change of funding costs paid by the bank, weighted by the levels of long- and short-term debt. ${ }^{28}$

\section{A satellite model should be used to link short- and long-term funding costs (as a} lagged term) to risk-weighted capital ratios (and/or leverage), loan loss provisions, funding gap and to simulate a non-linear effect with respect to default risk. If the firm's existing approach does not meet this precondition, the following approaches to approximate the macro-financial linkages of short-term funding costs are suggested - one model based on historical inference (Appendix III, Option 1) as well as a refined approach of what has been done in the Global Financial Stability Report (GFSR), based on a reduced form estimation using an advanced contingent claims analysis (CCA) framework (Appendix III, Option 2). The cost of the short-term funding shock cannot be smaller than those provided under either method. In absence of a suitable model, the cost of long-term funding can be derived using expert judgment.

- The first approach ("historical inference") represents an aggregate funding risk model using country-level data to determine the relation between Moody's KMV Expected Default Frequencies (EDFs) and (weighted-average) funding costs, i.e., taking into account the relative importance of different funding sources for specific countries as well as their costs (Option 1). The risk-based capital ratios for a series of rating grades are inferred from the Basel II capital model, by using the confidence level corresponding to the EDFs of banks. The method is heavily based on empirical data and determines changes in the cost of debt for the average banking sector. The idea is to determine the additional costs of underperformance of bank under stress resulting from funding.

- The second approach ("advanced CCA") provides an enhanced CCA-based projection of funding costs as a non-linear function of changes in asset values of individual banks, conditional on their leverage and liability structure (Option 2). Funding costs increase in response to a perceived erosion of asset values due to net loss in times of stress. ${ }^{29}$ The implied asset value of each bank is estimated using the Gram-Charlier extension to the conventional Merton (1974) option pricing formula based on equity market information. Then the change in the fair value credit spread is determined before and after a change to the asset value (as proxy for the marginal funding cost) for a given adverse scenario.

\footnotetext{
${ }^{28}$ Assumptions of funding cost in liquidity stress tests should be aligned with the stress parameters affecting the solvency condition of banks on a best effort basis.

${ }^{29} \mathrm{We}$ account for revenues but not the extent to which these losses themselves have been attributable to higher funding cost.
} 
Valuation changes to fixed income holdings

27. The mark-to-market test of fixed income securities focuses on the projection of haircuts for holdings of both sovereign and bank debt. These haircuts will be applied to both the trading and banking books. Cash at central banks as well as repos or asset swaps where there is no economic interest in the security-for instance, instruments held against assets pledged to the $\mathrm{BoE}$ - are excluded. Moreover, haircuts will be applied only to nonAAA sovereigns.

\section{Government debt holdings (sovereign risk)}

28. For sovereign risk relating to both local and foreign government debt, firms are asked to adopt IMF estimates based on an assumed increase of sovereign distress consistent with market expectations, but does not entail a general shift in the yield curve (Table 3 ). We project the future yield-to-maturity (and associated haircut) based on changes in the market-implied default probability inferred from forward contracts on the country-specific sovereign credit default swap (CDS) spread, while excluding a common upward shift in yield curves (Appendix IV). The dynamics of monthly variations of expected default risk underpinning the changes of the sovereign CDS term structure between January 2009 and December 2010 are parametrically calibrated to inform estimates of default risk (and haircuts relative to end-2010) for each year of the forecast horizon. For the baseline, the median $\left(50^{\text {th }}\right.$ percentile $)$ is chosen. Haircuts under the adverse scenario take into account the volatility of market expectations of sovereign risk by assuming country-specific shocks at the $75^{\text {th }}$ and $90^{\text {th }}$ percentile of the probability distribution of default risk prior to the forecast horizon.

\section{Bank debt holdings (banking sector risk)}

29. The determination of haircuts for bank debt follows the assessment of sovereign risk. The recent crystallization of sovereign risk and its effects on government bond spreads has also been associated with rising spreads on bank debt. This has been reflected in a weakening in the implicit sovereign guarantee to banks, a lowering in the value of government bonds held by banks, and expected downgrades to banks following cuts to sovereign credit ratings. In all scenarios, the same haircuts are applied to firms' holdings of bonds issued by other banks.

Remark: Excel spreadsheets for all funding and sovereign risk calculations are available upon request.

\section{Valuation changes of net open positions due to foreign exchange (FX) shocks}

30. Firms are asked to report separately the aggregate impact of FX shocks on net open positions in terms of a decline of the U.S. dollar, the euro and the Japanese yen vis-àvis the pound sterling: 
The shock for each currency should be based on two (four) standard deviations of the FX volatility during 2010 with respect to the mild and severe "double dip" scenario respectively.

Unexpected changes in FX rates translate into higher RWAs for market risk only and do not generate any knock-on effects on other elements of the stress test.

The shock should increase associated RWAs in 2011 (100 percent) and 2012 (50 percent) only.

Table 3. Debt Haircuts, as of December 31, 2010 (In percent)

\begin{tabular}{|c|c|c|c|c|c|c|c|c|c|c|c|c|c|c|c|}
\hline \multirow[b]{3}{*}{ Forecast Year } & \multicolumn{15}{|c|}{5 -year rate } \\
\hline & \multicolumn{5}{|c|}{ Baseline } & \multicolumn{5}{|c|}{ Adverse 1 (Double Dip (mild) and Slow Growth) } & \multicolumn{5}{|c|}{ Adverse 2 (Double Dip (severe)) } \\
\hline & 2011 & 2012 & 2013 & 2014 & 2015 & 2011 & 2012 & 2013 & 2014 & 2015 & 2011 & 2012 & 2013 & 2014 & 2015 \\
\hline Belgium & 1.76 & 1.88 & 1.79 & 1.66 & 1.55 & 4.56 & 4.74 & 4.61 & 4.42 & 4.26 & 9.49 & 9.84 & 9.55 & 9.12 & 8.71 \\
\hline France & 0.00 & 0.04 & 0.05 & 0.03 & 0.01 & 0.77 & 1.03 & 1.09 & 0.99 & 0.90 & 3.18 & 3.66 & 3.79 & 3.62 & 3.45 \\
\hline Germany & 0.00 & 0.00 & 0.02 & 0.00 & 0.00 & 0.30 & 0.41 & 0.45 & 0.43 & 0.43 & 1.37 & 1.66 & 1.84 & 1.82 & 1.79 \\
\hline Netherlands & 0.30 & 0.34 & 0.35 & 0.34 & 0.34 & 0.61 & 0.68 & 0.71 & 0.70 & 0.70 & 1.81 & 1.90 & 1.99 & 2.00 & 2.03 \\
\hline UK & 0.10 & 0.27 & 0.25 & 0.10 & 0.16 & 1.19 & 1.39 & 1.31 & 1.02 & 1.03 & 3.16 & 3.41 & 3.23 & 2.69 & 2.60 \\
\hline Greece & 12.77 & 10.85 & 9.07 & 8.21 & 7.28 & 26.61 & 23.20 & 20.00 & 18.56 & 16.81 & 46.55 & 41.57 & 36.74 & 34.61 & 31.82 \\
\hline Ireland & 6.12 & 5.55 & 4.77 & 4.26 & 3.78 & 13.83 & 12.81 & 11.39 & 10.56 & 9.59 & 26.35 & 24.71 & 22.35 & 21.05 & 19.34 \\
\hline Italy & 2.75 & 2.78 & 2.72 & 2.55 & 2.44 & 5.66 & 5.64 & 5.58 & 5.36 & 5.18 & 10.77 & 10.67 & 10.60 & 10.31 & 10.01 \\
\hline Portugal & 2.25 & 1.76 & 0.94 & 0.27 & 0.00 & 10.72 & 9.72 & 8.06 & 6.77 & 5.64 & 24.40 & 22.68 & 19.82 & 17.60 & 15.63 \\
\hline Spain & 1.90 & 1.73 & 1.56 & 1.37 & 1.25 & 6.10 & 5.74 & 5.44 & 5.17 & 5.02 & 13.35 & 12.66 & 12.16 & 11.76 & 11.56 \\
\hline United States & 0.14 & 0.17 & 0.20 & 0.21 & 0.23 & 0.36 & 0.49 & 0.65 & 0.75 & 0.85 & 1.34 & 1.74 & 2.14 & 2.39 & 2.60 \\
\hline \multicolumn{16}{|c|}{ Memo item: CEBS haircuts (absolute) } \\
\hline Belgium & 1.40 & 3.10 & - & - & - & 3.47 & 6.51 & - & - & - & & & & & \\
\hline France & 1.50 & 3.00 & - & - & - & 2.21 & 4.93 & - & - & - & & & & & \\
\hline Germany & 0.10 & 2.30 & - & - & - & 2.03 & 3.69 & - & - & - & & & & & \\
\hline Netherlands & 1.10 & 2.50 & - & - & - & 1.79 & 4.83 & - & - & - & & & & & \\
\hline UK & 5.00 & 6.90 & - & - & - & 2.56 & 5.52 & - & - & - & & & & & \\
\hline Greece & 3.90 & 4.30 & - & - & - & 22.60 & 30.22 & - & - & - & & & & & \\
\hline Ireland & 1.60 & 4.20 & - & - & - & 7.58 & 11.11 & - & - & - & & & & & \\
\hline Italy & 1.20 & 2.90 & - & - & - & 3.96 & 7.10 & - & - & - & & & & & \\
\hline Portugal & 2.30 & 3.70 & - & - & - & 10.94 & 15.92 & - & - & - & & & & & \\
\hline Spain & 1.30 & 4.10 & - & - & - & 6.55 & 9.86 & - & - & - & & & & & \\
\hline US & 1.30 & 4.40 & - & - & - & 4.41 & 9.37 & - & - & - & & & & & \\
\hline \multicolumn{16}{|c|}{ Memo item: Difference between new haircuts and CEBS haircuts } \\
\hline Belgium & 0.36 & -1.22 & - & - & - & 1.09 & -1.77 & - & - & - & & & & & \\
\hline France & -1.50 & -2.96 & - & - & - & -1.44 & -3.91 & - & - & - & & & & & \\
\hline UK & -4.90 & -6.63 & - & - & - & -1.37 & -4.14 & - & - & - & & & & & \\
\hline & 0.00 & 0.00 & & & & 0.00 & 0.00 & & & & & & & & \\
\hline Greece & 8.87 & 6.55 & - & - & - & 4.01 & -7.03 & - & - & - & & & & & \\
\hline Ireland & 4.52 & 1.35 & - & - & - & 6.25 & 1.70 & - & - & - & & & & & \\
\hline Italy & 1.55 & -0.12 & - & - & - & 1.70 & -1.46 & - & - & - & & & & & \\
\hline Portugal & -0.05 & -1.94 & - & - & - & -0.22 & -6.20 & - & - & - & & & & & \\
\hline Spain & 0.60 & -2.37 & - & - & - & -0.45 & -4.13 & - & - & - & & & & & \\
\hline US & -1.16 & -4.23 & - & - & - & -4.05 & -8.88 & - & - & - & & & & & \\
\hline
\end{tabular}




\section{Hurdle RATES: BaSel III}

31. Firms are required to assess solvency in accordance with recent changes of regulatory rules pursuant to agreements published by the Basel Committee on Banking Supervision (BCBS) in September and December 2010 (Figure 3). The recent changes include:

- $\quad$ higher in minimum capital requirement ratios, i.e., Tier 1 and common equity (core capital);

- a more restrictive definition of eligible capital (“capital deductions”);

- $\quad$ higher asset risk-weightings; and

- $\quad$ the introduction of a maximum leverage ratio. ${ }^{30}$

32. Under this published schedule, firms will need to meet the following new minimum capital requirements in relation to RWAs as of January 1, 2013 (Table 4): 3.5 percent common equity/RWAs (up from 2.0 percent) and 4.5 percent Tier 1 capital/RWAs (up from 3.0 percent), in addition to the existing capital adequacy ratio (CAR) of 8.0 percent total capital/RWAs. These capital requirements are supplemented by a minimum Tier 1 leverage ratio of 3.0 percent. ${ }^{31}$ The regulatory adjustments (i.e., deductions and prudential filters), including amounts above the aggregate 15 percent limit for investments in financial institutions, mortgage servicing rights, and deferred tax assets from timing differences, are scheduled to begin on January $1,2014 .{ }^{32}$

\section{The definition of capital at end-2010 should be consistent with the FSA} guidelines, subject to phase-in, phase-out and grandfathering considerations:

- $\quad$ The starting point for core Tier 1 and Tier 1 should be the official definitions as laid out in the FSA Handbook. ${ }^{33}$

\footnotetext{
${ }^{30}$ See http://www.bis.org/press/p100912.htm.

${ }^{31}$ The changes in minimum capital requirements also have to be taken into account for counterparty risk and market risk considerations.

${ }^{32}$ In particular, the regulatory adjustments will begin at 20 percent of the required deductions from common equity on January 1, 2014 and 40 percent on January 1, 2015. During this transition period, the remainder not deducted from common equity will continue to be subject to existing national treatments.

${ }^{33}$ See http://fsahandbook.info/FSA/html/handbook/GENPRU/2/Annex2.
} 
- $\quad$ For the phase-in of capital deductions, 20 percent (per annum) of core Tier 1 capital (such as deferred tax assets and minority interests that exceed the permissible limit) are deducted in 2014 and 2015. Firms must document deductions if the amount core Tier 1 to be phased out is less than 41.3 percent (which is the average value for large banks according to QIS-6).

- $\quad$ For the phase-out of non-core Tier 1 and Tier 2 capital elements, it is the lower of either 10 percent (per annum) of the amount of capital to be phased-out or the amount of maturing capital maturing each year subject to phase out between 2013 and 2015.

- $\quad$ Existing capital instruments are not grandfathered until they mature for the Tier in which they currently belong.

Figure 3. Overview of the Basel III Minimum Capital Requirements ${ }^{34}$

\begin{tabular}{|c|c|c|c|c|c|c|c|c|c|}
\hline \multicolumn{10}{|c|}{$\begin{array}{l}\text { Annex 2: Phase-in arrangements (shading indicates transition periods) } \\
\qquad \text { (all dates are as of } 1 \text { January) }\end{array}$} \\
\hline & 2011 & 2012 & 2013 & 2014 & 2015 & 2016 & 2017 & 2018 & $\begin{array}{l}\text { As of } \\
1 \text { January } \\
2019\end{array}$ \\
\hline Leverage Ratio & \multicolumn{2}{|c|}{ Supevisory monitoring } & \multicolumn{4}{|c|}{$\begin{array}{c}\text { Parallel run } \\
\text { 1 Jan 2013- } 1 \text { Jan } 2017 \\
\text { Disclosure starts 1 Jan } 2015\end{array}$} & & $\underset{\text { Pillar } 1}{\text { Mgrato to }}$ & \\
\hline Minimum Common Equity Capital Ratio & & & $3.5 \%$ & $4.0 \%$ & $4.5 \%$ & $4.5 \%$ & $4.5 \%$ & $4.5 \%$ & $4.5 \%$ \\
\hline Capital Conservation Buffer & & & & & & $0.625 \%$ & $1.25 \%$ & $1.875 \%$ & $2.50 \%$ \\
\hline $\begin{array}{l}\text { Minimum common equity plus capital } \\
\text { conservation buffer }\end{array}$ & & & $3.5 \%$ & $4.0 \%$ & $4.5 \%$ & $5.125 \%$ & $5.75 \%$ & $6.375 \%$ & $7.0 \%$ \\
\hline $\begin{array}{l}\text { Phase-in of deductions from CET1 } \\
\text { (including amounts exceeding the limit for } \\
\text { DIAs, MSKS and tinanclals ) }\end{array}$ & & & & $20 \%$ & $40 \%$ & $60 \%$ & $80 \%$ & $100 \%$ & $100 \%$ \\
\hline Minimum Tier 1 Capital & & & $4.5 \%$ & $5.5 \%$ & $6.0 \%$ & $6.0 \%$ & $6.0 \%$ & $6.0 \%$ & $6.0 \%$ \\
\hline Minimum Total Capital & & & $8.0 \%$ & $8.0 \%$ & $8.0 \%$ & $8.0 \%$ & $8.0 \%$ & $8.0 \%$ & $8.0 \%$ \\
\hline $\begin{array}{l}\text { Minimum Total Capital plus conservation } \\
\text { buffer }\end{array}$ & & & $8.0 \%$ & $8.0 \%$ & $8.0 \%$ & $8.625 \%$ & $9.25 \%$ & $9.875 \%$ & $10.5 \%$ \\
\hline $\begin{array}{l}\text { Capital instruments that no longer qualify, } \\
\text { as non-cure Tier } 1 \text { capilal or Tier } 2 \text { capilal }\end{array}$ & & & \multicolumn{7}{|c|}{ Phased out over 10 year horizon beginning 2013} \\
\hline I iquidity coverage ratio & $\begin{array}{c}\text { Observation } \\
\text { period } \\
\text { begirs }\end{array}$ & & & & $\begin{array}{l}\text { Introduce } \\
\text { mininum } \\
\text { standard }\end{array}$ & & & & \\
\hline Net stable funding ratio & & $\begin{array}{c}\text { Observation } \\
\text { period } \\
\text { begins }\end{array}$ & & & & & & $\begin{array}{l}\text { Introduce } \\
\text { minimum } \\
\text { stancard }\end{array}$ & \\
\hline
\end{tabular}

${ }^{34}$ See http://www.bis.org/press/p100912.htm. 
Table 4. Capital Hurdle Rates

(In percent)

\begin{tabular}{|c|c|c|c|c|c|}
\hline \multirow[b]{2}{*}{ Forecast Year } & \multicolumn{5}{|c|}{ Applied Capital Hurdle Rates } \\
\hline & 2011 & 2012 & 2013 & 2014 & 2015 \\
\hline & \multicolumn{5}{|c|}{ without capital buffer } \\
\hline Core Tier 1 (common equity) capital & 2.0 & 2.0 & 3.5 & 4.0 & 4.5 \\
\hline Tier 1 capital & 4.0 & 4.0 & 4.5 & 5.5 & 6.0 \\
\hline \multirow[t]{2}{*}{ Total capital } & 8.0 & 8.0 & 8.0 & 8.0 & 8.0 \\
\hline & \multicolumn{5}{|c|}{ with capital buffer } \\
\hline Core Tier 1 (common equity) capital & 3.0 & 3.0 & 4.5 & 5.0 & 5.5 \\
\hline Tier 1 capital & 5.0 & 5.0 & 5.5 & 6.5 & 7.0 \\
\hline Total capital & 10.5 & 10.5 & 10.5 & 10.5 & 10.5 \\
\hline
\end{tabular}

34. Higher RWAs, which will take effect as of January 1, 2011, should be taken into account with some form of expert judgment:

- $\quad$ Changes in risk-weights for all risk types (credit, market and operational risk) increase equal to baseline nominal GDP growth (by accounting for business volume) throughout the forecast period. ${ }^{35}$ For credit and market risk, there should be an additional cumulative increase by at least 15.3 percent and 7.6 percent respectively between 2013 and 2015 per Table 5 (consistent with QIS-6 results for large banks). For the former, the minimum increase of RWAs applies to performing loans only.

- Alternatively, firms may choose to estimate their own risk weights using available internal models (as of end-2010) while selecting minimum increases in risk weights only for certain sub-categories, such as securitization in the trading and/or banking book. Lower values for the changes in risk weights for credit and market risk need to be documented and approved by the FSA during the review process.

- $\quad$ The risk-weights for credit risk are subsequently reduced by the RWAs of defaulted exposures, which should be approximated by taking 2.5 times the average RWAs for non-defaulted exposures (accounting for the fact that risk-weights for defaulted exposures were higher prior to default).

\footnotetext{
${ }^{35}$ Basel Committee for Banking Supervision, 2010, "Results of the Comprehensive Quantitative Impact Study," BCBS Publication No. 186 (December).
} 
35. Firms should test the sensitivity of results to a voluntary capital buffer in anticipation of the graduated introduction of capital cushion for pro-cyclicality ("Capital Conservation Buffer") past the forecast horizon. In order to account for the fact that banks have historically held more capital than needed, a (voluntary) capital buffer above the total capital $(+2.5$ percentage points), the Tier 1 capital ratio $(+1.0$ percentage point), and core Tier 1 capital ( +1.0 percentage point) starting in 2011 are considered as a separate scenario.

36. This additional test using hurdle rates with capital buffers are for sensitivity check only. Firms will not be deemed to have actually "failed" if they do not meet those benchmarks and the results will not be published. 


\section{Table 5. Risk-Weighted Assets}

\begin{tabular}{|c|c|c|c|c|c|c|c|}
\hline \multirow[b]{2}{*}{ Forecast Year } & \multicolumn{6}{|c|}{ Changes in Risk-Weighted Assets (In percent) } & \\
\hline & & 2011 & 2012 & 2013 & 2014 & 2015 & \\
\hline & \multirow{2}{*}{\multicolumn{6}{|c|}{ Option 1: General Risk-Weights (for broad risk types) }} & \\
\hline & & & & & & & \\
\hline Credit risk 1/ & $\begin{array}{l}- \\
+\end{array}$ & $\begin{array}{c}4.75 \\
\text { up to } 13.0 \\
-\end{array}$ & $\begin{array}{c}4.14 \\
\text { up to } 13.0 \\
-\end{array}$ & $\begin{array}{c}4.16 \\
\text { up to } 14.0 \\
5.10\end{array}$ & $\begin{array}{c}4.17 \\
\text { up to } 16.0 \\
5.10\end{array}$ & $\begin{array}{c}4.32 \\
\text { up to } 17.0 \\
5.10\end{array}$ & $\begin{array}{l}\text { nominal GDP grow th } \\
\text { de-leveraging rule } \\
\text { Basel III impact (QIS-6) }\end{array}$ \\
\hline Market risk $2 /$ & + & 4.75 & 4.14 & $\begin{array}{l}4.16 \\
2.53\end{array}$ & $\begin{array}{l}4.17 \\
2.53\end{array}$ & $\begin{array}{l}4.32 \\
2.53\end{array}$ & nominal GDP grow th \\
\hline \multirow[t]{2}{*}{ Operational risk } & & 4.75 & 4.14 & 4.16 & 4.17 & 4.32 & nominal GDP grow th \\
\hline & \multicolumn{6}{|c|}{ "Double Dip" Recession Scenario (mild) } & \\
\hline Credit risk $1 /$ & $\begin{array}{l}- \\
+\end{array}$ & $\begin{array}{c}1.66 \\
\text { up to } 13.0 \\
-\end{array}$ & $\begin{array}{c}1.08 \\
\text { up to } 13.0 \\
-\end{array}$ & $\begin{array}{c}3.44 \\
\text { up to } 14.0 \\
5.10\end{array}$ & $\begin{array}{c}4.51 \\
\text { up to } 16.0 \\
5.10\end{array}$ & $\begin{array}{c}4.74 \\
\text { up to } 17.0 \\
5.10\end{array}$ & $\begin{array}{l}\text { nominal GDP grow th } \\
\text { de-leveraging rule } \\
\text { Basel III impact (QIS-6) }\end{array}$ \\
\hline Market risk $2 /$ & + & $\begin{array}{c}1.66 \\
-\end{array}$ & $\begin{array}{c}1.08 \\
-\end{array}$ & $\begin{array}{l}3.44 \\
2.53\end{array}$ & $\begin{array}{l}4.51 \\
2.53\end{array}$ & $\begin{array}{l}4.74 \\
2.53\end{array}$ & $\begin{array}{l}\text { nominal GDP grow th } \\
\text { Basel III impact (QIS-6) }\end{array}$ \\
\hline \multirow[t]{2}{*}{ Operational risk } & & 1.66 & 1.08 & 3.44 & 4.51 & 4.74 & nominal GDP grow th \\
\hline & \multicolumn{6}{|c|}{ "Double Dip" Recession Scenario (severe) } & \\
\hline Credit risk 1/ & $\begin{array}{l}- \\
+\end{array}$ & $\begin{array}{c}3.53 \\
\text { up to } 13.0 \\
-\end{array}$ & $\begin{array}{c}1.41 \\
\text { up to } 13.0 \\
-\end{array}$ & $\begin{array}{c}3.61 \\
\text { up to } 14.0 \\
5.10\end{array}$ & $\begin{array}{c}5.08 \\
\text { up to } 16.0 \\
5.10\end{array}$ & $\begin{array}{c}4.78 \\
\text { up to } 17.0 \\
5.10\end{array}$ & $\begin{array}{l}\text { nominal GDP grow th } \\
\text { de-leveraging rule } \\
\text { Basel III impact (QIS-6) }\end{array}$ \\
\hline Market risk $2 /$ & + & $\begin{array}{c}3.53 \\
-\end{array}$ & $\begin{array}{c}1.41 \\
-\end{array}$ & $\begin{array}{l}3.61 \\
2.53\end{array}$ & $\begin{array}{l}5.08 \\
2.53\end{array}$ & $\begin{array}{l}4.78 \\
2.53\end{array}$ & $\begin{array}{l}\text { nominal GDP grow th } \\
\text { Basel III impact (QIS-6) }\end{array}$ \\
\hline \multirow[t]{2}{*}{ Operational risk } & & 3.53 & 1.41 & 3.61 & 5.08 & 4.78 & nominal GDP grow th \\
\hline & \multicolumn{6}{|c|}{ "Slow Growth" Scenario } & \\
\hline Credit risk $1 /$ & $\begin{array}{l}- \\
+\end{array}$ & $\begin{array}{c}4.87 \\
\text { up to } 13.0 \\
-\end{array}$ & $\begin{array}{c}3.78 \\
\text { up to } 13.0 \\
-\end{array}$ & $\begin{array}{c}2.87 \\
\text { up to } 14.0 \\
5.10\end{array}$ & $\begin{array}{c}3.08 \\
\text { up to } 16.0 \\
5.10\end{array}$ & $\begin{array}{c}2.97 \\
\text { up to } 17.0 \\
5.10\end{array}$ & $\begin{array}{l}\text { nominal GDP grow th } \\
\text { de-leveraging rule } \\
\text { Basel III impact (QIS-6) }\end{array}$ \\
\hline Market risk $2 /$ & + & $\begin{array}{c}4.87 \\
-\end{array}$ & $\begin{array}{c}3.78 \\
-\end{array}$ & $\begin{array}{l}2.87 \\
2.53\end{array}$ & $\begin{array}{l}3.08 \\
2.53\end{array}$ & $\begin{array}{l}2.97 \\
2.53\end{array}$ & $\begin{array}{l}\text { nominal GDP grow th } \\
\text { Basel III impact (QIS-6) }\end{array}$ \\
\hline Operational risk & & 4.87 & 3.78 & 2.87 & 3.08 & 2.97 & nominal GDP grow th \\
\hline
\end{tabular}

Option 2: Selected Risk-Weights (for specific risk types)

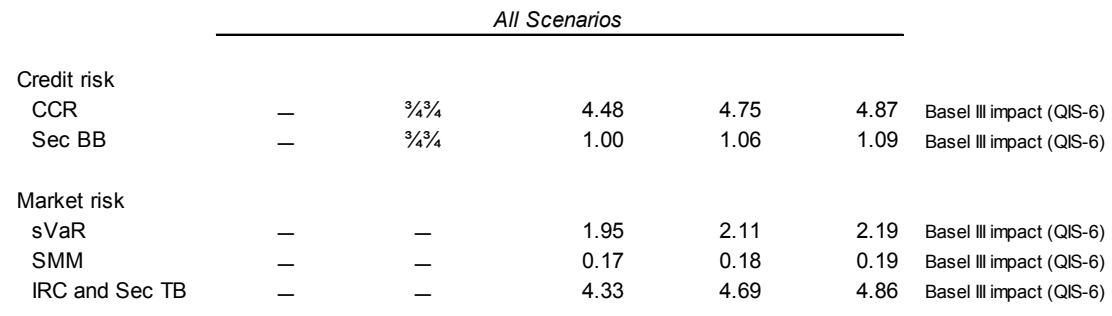

1/ excludes defaulted loans ( $w$ hich are subject to a separate treatment). Note: The change in RWA per year for each risk type and under each scenario is determined by the change in nominal GDP (except for selected risk-w eights) and one-third of the impact of Basel III (for credit and market risk according to QIS-6) per year betw een 2013 and 2015 (based on the QIS-6 results). Firms can either adopt the catch-all change of minimum RWAs or choose to supplement ow $n$ RWA models $w$ ith minimum estimates of RWAs in certain subcategories of credit and market risk, such as counterparty credit risk (CCR), securitization in the banking book (Sec BB), stressed Value-at-Risk (sVaR), equity standard measurement method (SMM), and incremental risk charge and securitization in the trading book (IRC and Sec TB). 2/ The impact of the FX shocks on market risk RWAs is estimated separately and added subsequently.

\section{CInternational Monetary Fund. Not for Redistribution}




\section{OutPut}

37. Firms assess capital adequacy under stress by reporting all capital measures for each year over the forecast horizon using the output template presented in Appendix V:

- $\quad$ These metrics comprise (i) total capital; (ii) Tier 1 capital; and (iii) common equity capital.

- $\quad$ Firms should also disclose the composition of capital in each period. In case of a capital shortfall, firms should show the calculated recapitalization needs.

- $\quad$ Results are aggregated by the FSA and reported for each year of the forecast time horizon with some measure of dispersion, such as the inter-quartile range (IQR), i.e., between the $25^{\text {th }}$ and the $75^{\text {th }}$ percentile of the distribution of capital adequacy levels. This aggregation removes the possibility that individual firms can be identified.

- $\quad$ The IMF will only publish results related to the stress test after consulting with the authorities and subject to the existing confidentiality agreement between the FSA and firms as well as IMF statutes that govern data confidentiality with national authorities.

38. Firms should report the major risk drivers (profitability, credit/trading losses, riskweights). They should show the marginal impact of (i) including haircuts on sovereign and financial sector debt holdings; (ii) FX shocks to net open positions; (iii) capital phasein/phase-out according to Basel III; and (iv) voluntary capital buffers.

\section{Firms should document their estimation of important stress testing elements,} such as funding costs, supervisory standards (risk-weightings), and macro-financial linkages ("satellite models" and/or expert judgment), and demonstrate their compliance with the IMFprovided minimum standards:

- $\quad$ The FSA will engage, on an ongoing basis, with the stress testing efforts of firms to help ensure consistency of underpinning assumptions and suitability of models prior to the submission of the stress test results.

- $\quad$ The results will also be sense-checked by the BoE and FSA against historical experience, other stress testing work by the firms, as well as by using results from a top-down version of the stress test exercise, processed using satellite models estimated based on aggregate data.

40. The proposed timeline for the completion of the bottom-up stress tests is presented in Appendix VI. 


\section{APPENDiX I. SUMmary OF SCENARIOS, KEY ASSUMPTIONS AND HURDLE RATES}

\begin{tabular}{|c|c|c|}
\hline Domain & Element & Specific Rules/Assumptions \\
\hline Scenarios & $\begin{array}{l}\text { (i) Baseline } \\
\text { (ii) "Double Dip (mild)" (approx. } 1 \\
\text { std. dev. from baseline) } \\
\text { (iii) "Double Dip (severe)" (2 std. } \\
\text { devs. from baseline) } \\
\text { (iv) "Slow Growth" }\end{array}$ & $\begin{array}{l}\text { - Macroeconomic/financial variables (GDP, interest rates, unemployment and inflation) } \\
\text { conditional on macro scenario. Models were run by FSA. } \\
\text { - Aim to ensure consistency with other European FSAPs (and with ECB/CEBS/EBA stress } \\
\text { tests). }\end{array}$ \\
\hline $\begin{array}{l}\text { (Risk) factors } \\
\text { assessed }\end{array}$ & $\begin{array}{l}\text { Loss rates } \\
\text { Profitability } \\
\text { Fixed income holdings } \\
\text { FX shock } \\
\text { Taxes }\end{array}$ & $\begin{array}{l}\text { - Credit losses based on satellite models developed by firms depending on scenario. } \\
\text { - Profit (interest income, interest expenses, net fee and commission income, and operating } \\
\text { expenses) should be based on firm's satellite models (or expert judgment). For end-2010, } \\
\text { net profit before tax should be adjusted for extraordinary income/losses in order to avoid } \\
\text { misleading results. } \\
\text { - Trading income based on satellite model or statistical matching of both trading income and } \\
\text { GDP growth using a parametric fit of their historical distribution (i.e., a decline in GDP } \\
\text { growth is assumed to result in lower trading income). } \\
\text { - Funding costs based on satellite model for interest expenses, including a non-linear effect. } \\
\text { Changes in funding costs due to different solvency conditions cannot be smaller than the } \\
\text { one generated by either some general funding cost sensitivity (Appendix III, Option 1) or } \\
\text { results from suggested CCA-based approach (Appendix III, Option 2). These changes are } \\
\text { unaffected by possible balance sheet deleveraging. } \\
\text { - Mark-to-market impact on fixed income holdings: Focuses on the projection of haircuts } \\
\text { for holdings of both sovereign and bank debt based on IMF approach. These haircuts will be } \\
\text { applied to both trading and banking book. } \\
\text { - Sovereign and financial sector debt holdings: Haircut on holdings in the banking and } \\
\text { trading books based on market expectations over five years after controlling for changes of }\end{array}$ \\
\hline
\end{tabular}




\begin{tabular}{|c|c|c|}
\hline Domain & Element & Specific Rules/Assumptions \\
\hline & & $\begin{array}{l}\text { market valuation during } 2010 \text { as developed by IMF staff (see Appendix IV). Cash at central } \\
\text { banks as well as repos or asset swaps where there is no economic interest in the security } \\
\text { (for instance, instruments held against assets pledged to the Bank of England) are } \\
\text { excluded. Moreover, haircuts will be applied only to issuers that are non-AAA rated. } \\
\text { - FX shock: Firms are asked to report separately the marginal impact of the following FX } \\
\text { shock of the following currencies on net open positions: U.S. dollar, euro and Japanese yen. } \\
\text { The shock for each currency should be twice the standard deviation of the respective FX } \\
\text { volatility during } 2010 \text { and impact the trading book in } 2011 \text { (100 percent) and } 2012 \text { (50 } \\
\text { percent) only. } \\
\text { Tax assumption: } 25 \text { percent in case of positive profits, zero otherwise. }\end{array}$ \\
\hline $\begin{array}{l}\text { Behavioral } \\
\text { adjustment of } \\
\text { banks }\end{array}$ & $\begin{array}{l}\text { Dividend pay-out rules (similar to } \\
\text { Basel III minima) } \\
\text { Credit growth } \\
\text { Asset disposal } \\
\text { Capital raising }\end{array}$ & $\begin{array}{l}\text { - Balance sheets are assumed to be constant and to grow in line with nominal GDP. } \\
\text { - Dividend payout depends on capitalization under stress: dividend pay-out only if firm } \\
\text { reports profits over the past year; if total capital ratio is above } 8.0 \text { percent (after the } \\
\text { envisaged dividend payout and, at the same time, exhibits sufficient Tier } 1 \text { and core Tier1 } \\
\text { capitalization) but below the } 10.5 \text { percent threshold (which reflects the magnitude of the } \\
\text { proposed "capital conservation buffer" under Basel III), the firm is considered capital- } \\
\text { constrained and needs to follow a payout schedule as displayed in Table } 2 \text {. } \\
\text { - Credit growth in line with nominal GDP for banks with a Tier } 1 \text { capital buffer of } 2.5 \\
\text { percentage points above the regulatory minimum; credit growth decreases by } 2 \text { percentage } \\
\text { points for each decrease in Tier } 1 \text { capital by } 1 \text { percentage point once the buffer is less than } \\
2.5 \text { percentage points. Hence, growth becomes negative when capitalization is at minimum } \\
\text { capital ratio. } \\
\text { - Other business strategy considerations: Asset disposals or acquisitions over time should } \\
\text { not be considered, except where legally binding commitments under EU state aid rules } \\
\text { exist. Maturing exposures are assumed to be replaced. Any interim capital-raising until end- } \\
2010 \text { can be considered in calculations. }\end{array}$ \\
\hline
\end{tabular}




\begin{tabular}{|c|c|c|}
\hline Domain & Element & Specific Rules/Assumptions \\
\hline $\begin{array}{l}\text { Regulatory } \\
\text { standards }\end{array}$ & $\begin{array}{l}\text { Capital requirements ('hurdle } \\
\text { rates'), } \\
\text { Changes in risk-weighted assets } \\
\text { (RWAs) } \\
\text { Capital phase-out/-in }\end{array}$ & $\begin{array}{l}\text { - Hurdle rates for core Tier } 1 \text { capital, Tier } 1 \text { capital, and total capital (CAR) according to } \\
\text { Basel III schedule (i.e., increasing from } 2013 \text { onwards). } \\
\text { - Changes in RWAs: Higher risk-weightings for trading assets, which will take effect as of } \\
\text { January } 1,2011 \text {, should be taken into account with some form of expert judgment. } \\
\text { Consistent with the comprehensive QIS-6, for credit and market risk, there should be a total } \\
\text { increase by } 9.3 \text { percent and } 7.6 \text { percent in RWAs between } 2013 \text { and } 2015 \text { (consistent with } \\
\text { QIS-6 results for large banks), in addition to a general increase of RWAs equal to nominal } \\
\text { GDP growth (by accounting for business volume) throughout the forecast period. Firms may } \\
\text { apply lower values for the initial increase of RWAs for credit and market risk if documented. } \\
\text { Where the calculation of Basel III risk weights for some exposure types (e.g., counterparty } \\
\text { credit risk) are difficult to estimate, risk weights are double those of the Basel II weights. } \\
\text { - Voluntary capital buffers: The graduated introduction of a capital cushion for pro-cyclicality } \\
\text { ("Capital Conservation Buffer") remains outside the scope of the solvency stress test; } \\
\text { however, firms are asked to provide results for a (voluntary) capital buffer above the total } \\
\text { capital (+2.5 percentage points), the Tier } 1 \text { capital ratio (+1.0 percentage point), and core } \\
\text { Tier } 1 \text { capital ( } 1.0 \text { percentage point) from } 2011 \text { as a separate scenario. } \\
\text { - RWA impact of default loans: RWA for credit risk reduced by } 2.5 \text { times of average risk } \\
\text { weight for defaulted loans (accounting for the fact that RWA for exposure subject to default } \\
\text { were higher prior to default). } \\
\text { The definition of capital during the forecast horizon has to comply with the envisaged } \\
\text { phase-in of capital deductions and the phase-out of non-eligible forms of capital, without } \\
\text { consideration of grandfathering. } \\
\text { Phase-in of capital deductions for core Tier } 1 \text { capital: } 20 \text { percent (per annum) of } \\
\text { core Tier } 1 \text { capital subject to phase-out deducted from core Tier } 1 \text { capital in } 2014 \text { and } \\
2015 \text { (such as goodwill, deferred tax assets and minority interests that exceed the } \\
\text { permissible limit); firms must document deductions if amount is below the average value } \\
\text { of } 41 \text { percent (QIS-6). }\end{array}$ \\
\hline
\end{tabular}




\begin{tabular}{|l|l|l|}
\hline Domain & Element & Specific Rules/Assumptions \\
\hline & & $\begin{array}{l}\text { Phase-out of non-core Tier 1 and Tier 2 capital elements: the higher of either 10 } \\
\text { percent (per annum) or the amount of maturing, non-eligible existing capital subject to } \\
\text { overall phase out between } 2013 \text { and } 2015 .\end{array}$ \\
\hline Outcome & $\begin{array}{l}\text { Reporting of results and } \\
\text { additional outputs } \\
\text { Output template }\end{array}$ & $\begin{array}{l}\text { - Output template: Firms report capital adequacy under stress by reporting the common } \\
\text { capital measures (total capital, Tier 1 capital and common equity capital) for each year over } \\
\text { the forecast horizon using the suggested output template. In case of a capital shortfall, } \\
\text { recapitalization needs are calculated. Firms should report the major risk drivers (profitability, } \\
\text { credit/trading losses, risk-weights) and show the marginal impact of including (i) haircuts on } \\
\text { sovereign and financial sector debt holdings; (ii) capital phase-in/phase-out according to } \\
\text { Basel III; (iii) voluntary capital buffers; as well as (iv) FX shocks to net open positions. In } \\
\text { addition, firms should report alternative stress test results without considering the } \\
\text { restrictions on the behavioral adjustment of banks as separate output. }\end{array}$ \\
& & \\
\hline
\end{tabular}




\section{Appendix II. Other Macroeconomic Variables}

\section{Appendix Table 1. Macroeconomic Projections from Simulated Shock to EU}

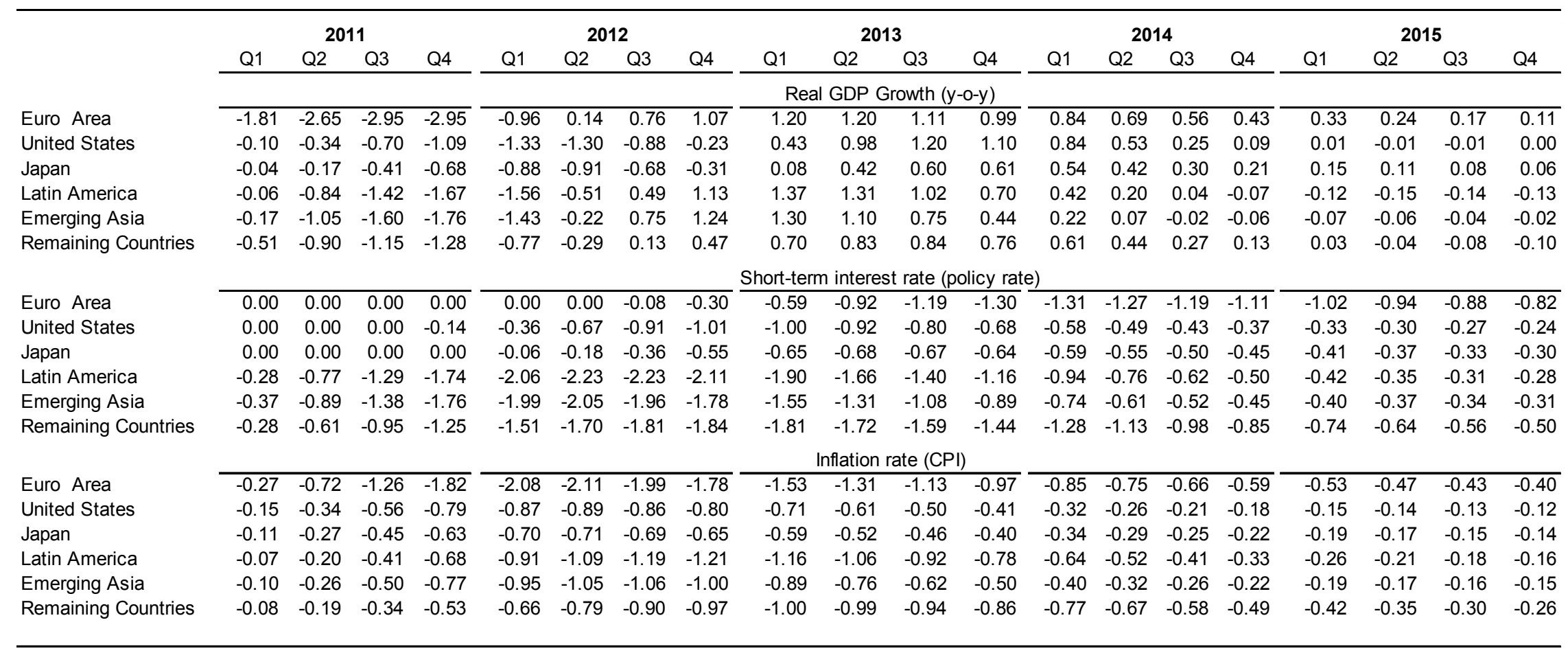

Note: Latin America (Brazil, Mexico, Colombia, Chile, Peru), Emerging Asia (China, India, Korea, Indonesia, Taiwan, Thailand, Malaysia, Hong Kong, Philippines, Singapore), and Remaining Countries (Russian, UK, Canada, Turkey, Australia, Argentina, South Africa, Venezuela, Sweden, Switzerland, Czech Republic, Denmark, Norway, Israel, Bulgaria, New Zealand, Estonia). 
Appendix Table 2. Macroeconomic Projections from Simulated Adverse Shock to EU and US interest rates (applies to baseline and all adverse scenarios).

\begin{tabular}{|c|c|c|c|c|c|c|c|c|c|c|c|c|c|c|c|c|c|c|c|c|}
\hline & \multicolumn{4}{|c|}{2011} & \multicolumn{4}{|c|}{2012} & \multicolumn{4}{|c|}{2013} & \multicolumn{4}{|c|}{2014} & \multicolumn{4}{|c|}{2015} \\
\hline & Q1 & Q2 & Q3 & Q4 & Q1 & Q2 & Q3 & Q4 & Q1 & Q2 & Q3 & Q4 & Q1 & Q2 & Q3 & Q4 & Q1 & Q2 & Q3 & Q4 \\
\hline & \multicolumn{20}{|c|}{ Long-term interest rate } \\
\hline & \multicolumn{20}{|c|}{ Baseline } \\
\hline Euro Area & 3.67 & 3.67 & 3.67 & 3.67 & 3.73 & 3.73 & 3.73 & 3.73 & 3.85 & 3.85 & 3.85 & 3.85 & 3.99 & 3.99 & 3.99 & 3.99 & 4.03 & 4.03 & 4.03 & 4.03 \\
\hline \multirow[t]{2}{*}{ United States } & 4.36 & 4.36 & 4.36 & 4.36 & 5.42 & 5.42 & 5.42 & 5.42 & 5.95 & 5.95 & 5.95 & 5.95 & 6.16 & 6.16 & 6.16 & 6.16 & 6.29 & 6.29 & 6.29 & 6.29 \\
\hline & \multicolumn{20}{|c|}{ Adverse Scenario(s) } \\
\hline Euro Area & 3.67 & 3.67 & 3.67 & 3.67 & 3.73 & 3.73 & 3.69 & 3.56 & 3.35 & 3.08 & 2.85 & 2.76 & 2.42 & 2.47 & 2.56 & 2.66 & 2.55 & 2.67 & 2.76 & 2.84 \\
\hline \multirow[t]{3}{*}{ United States } & 4.36 & 4.36 & 4.36 & 4.35 & 5.31 & 5.21 & 5.13 & 5.10 & 5.34 & 5.39 & 5.46 & 5.54 & 5.51 & 5.61 & 5.68 & 5.74 & 5.68 & 5.74 & 5.79 & 5.85 \\
\hline & \multicolumn{20}{|c|}{ Short-term interest rate } \\
\hline & \multicolumn{20}{|c|}{ Baseline } \\
\hline Euro Area & 1.06 & 1.06 & 1.06 & 1.06 & 1.36 & 1.36 & 1.36 & 1.36 & 1.76 & 1.76 & 1.76 & 1.76 & 2.18 & 2.18 & 2.18 & 2.18 & 2.39 & 2.39 & 2.39 & 2.39 \\
\hline \multirow[t]{2}{*}{ United States } & 0.29 & 0.29 & 0.29 & 0.29 & 1.31 & 1.31 & 1.31 & 1.31 & 2.26 & 2.26 & 2.26 & 2.26 & 3.26 & 3.26 & 3.26 & 3.26 & 4.07 & 4.07 & 4.07 & 4.07 \\
\hline & \multicolumn{20}{|c|}{ Adverse Scenario(s) } \\
\hline Euro Area & 1.06 & 1.06 & 1.06 & 1.06 & 1.36 & 1.36 & 1.28 & 1.06 & 1.17 & 0.84 & 0.57 & 0.46 & 0.87 & 0.91 & 0.99 & 1.07 & 1.37 & 1.45 & 1.51 & 1.57 \\
\hline United States & 0.29 & 0.29 & 0.29 & 0.15 & 0.95 & 0.64 & 0.40 & 0.30 & 1.26 & 1.34 & 1.46 & 1.58 & 2.68 & 2.77 & 2.83 & 2.89 & 3.74 & 3.77 & 3.80 & 3.83 \\
\hline
\end{tabular}




\section{APPENDix III: Alternative Funding Risk MODELS}

\section{Option 1: Simple Empirical Estimation}

Appendix Table 3. Minimum Funding Cost: Empirical Estimation of Non-Linear Change

\begin{tabular}{|c|c|c|c|c|c|}
\hline $\begin{array}{c}\text { Rating Scale } \\
\text { (Moody's) }\end{array}$ & $\begin{array}{c}\text { Rating } \\
\text { (S\&P, Fitch) }\end{array}$ & $\begin{array}{c}\text { One Year } \\
\text { PDs }\end{array}$ & $\begin{array}{l}\text { Funding costs } \\
\text { (Spread above } \\
\text { t-bills, bps) }\end{array}$ & $\begin{array}{c}\text { Economic } \\
\text { capital ratio } \\
\text { (Basel II (quasi- } \\
\text { IRB) }\end{array}$ & $\begin{array}{c}\text { Change of } \\
\text { Funding } \\
\text { spread (CAR } \\
\text { Elasticitity) }\end{array}$ \\
\hline Aaa & AAA & $0.004 \%$ & 8.73 & 0.281 & \\
\hline Aa1 & $\mathrm{AA}+$ & $0.006 \%$ & 8.74 & 0.273 & $0.00 \%$ \\
\hline $\mathrm{Aa} 2$ & AA & $0.008 \%$ & 8.74 & 0.262 & $0.00 \%$ \\
\hline Aa3 & AA- & $0.010 \%$ & 8.9 & 0.212 & $0.00 \%$ \\
\hline A1 & $A+$ & $0.012 \%$ & 9.0 & 0.197 & $0.00 \%$ \\
\hline A & A & $0.026 \%$ & 11.9 & 0.143 & $0.01 \%$ \\
\hline A2 & A- & $0.060 \%$ & 12.7 & 0.139 & $0.02 \%$ \\
\hline Baa1 & BBB+ & $0.135 \%$ & 21.0 & 0.117 & $0.04 \%$ \\
\hline Baa2 & BBB & $0.200 \%$ & 25.9 & 0.111 & $0.08 \%$ \\
\hline Baa3 & BBB- & $0.291 \%$ & 44.6 & 0.099 & $0.15 \%$ \\
\hline Ba1 & $\mathrm{BB}+$ & $0.682 \%$ & 92.7 & 0.085 & $0.35 \%$ \\
\hline Ba2 & BB & $0.728 \%$ & 98.4 & 0.084 & $0.57 \%$ \\
\hline Ba3 & BB- & $1.791 \%$ & 229.4 & 0.071 & $1.03 \%$ \\
\hline B1 & $B+$ & $2.450 \%$ & 310.5 & 0.067 & $2.01 \%$ \\
\hline B2 & B & $3.827 \%$ & 480.2 & 0.062 & $3.16 \%$ \\
\hline B3 & B- & $7.666 \%$ & 953.1 & 0.054 & $6.37 \%$ \\
\hline Caa1 & $\mathrm{CCC}+$ & $9.150 \%$ & 1135.9 & 0.053 & $10.74 \%$ \\
\hline Caa2 & $\mathrm{CCC}$ & $16.388 \%$ & 2027.6 & 0.048 & $17.69 \%$ \\
\hline Caa3 & CCC- & $24.806 \%$ & n.a. & n.a. & $24.63 \%$ \\
\hline $\mathrm{Ca} / \mathrm{C}$ & $\mathrm{C} / \mathrm{CC}$ & $32.949 \%$ & n.a. & n.a. & $31.58 \%$ \\
\hline
\end{tabular}

Note: Funding cost exclude the cost of equity. The economic capital ratio includes a capital buffer above the hurdle rate of 2.5 percentage points. 


\section{Option 2: Contingent Claims Analysis (CCA)}

The CCA-based projection of funding costs assumes that the average funding cost before the accrual of net losses during a given year is defined as spread $s=-T^{-1} \ln \left(1-P_{G C} / B e^{-r T}\right)$, where the firm's implied put option (using the Gram-Charlier extension) is defined as:

$$
P_{G C}=B e^{-r T}\left(1-\Phi\left(d_{1}-\sigma_{A}\right)\right)+A_{t}\left(\Phi\left(d_{1}\right)+\Phi\left(d_{1}\right) \sigma_{A}\left(\begin{array}{l}
\frac{\gamma_{1 T}}{3 !}\left(2 \sigma_{A}-d_{1} \sqrt{T}\right) \\
-\frac{\gamma_{2 T}}{4 !}\left(1-d_{1}^{2}+3 d_{1} \sigma_{A}-3 \sigma_{A}^{2}\right)
\end{array}\right)-1\right),
$$

with "distance-to-default $d_{1}$, skewness $\gamma_{1 T}$ and kurtosis $\gamma_{2 T}$ over maturity term $T=1$, standard normal density $\Phi($.$) , and debt service obligation (defined by the so-called "default$ barrier" $B e^{-r T}$ ), which is the present value of outstanding debt. The asset volatility, $\sigma_{A}$, is calculated as:

$$
\sigma_{A}=\sigma_{E}\left[1-\frac{B e^{-r T}}{A} \frac{\Phi\left(d_{1}-\sigma_{A} \sqrt{T}\right)}{\Phi\left(d_{1}\right)}\right]
$$

with bank equity volatility, $\sigma_{E}$, taken as the 3-month at-the-money implied volatility of the bank's equity price. The value of implied assets $A$ is determined from solving both equations above simultaneously.

The funding cost after the accrual of net losses is obtained by reducing the implied assets and increasing asset volatility accordingly. For a lower asset value $A$, asset volatility is adjusted utilizing the underlying asset dynamics of the Merton model, which yields the implied asset volatility under risk-neutrality:

$$
P=B e^{-r T} \exp \left(\left(1-\Phi\left(d_{1}\right)\right) \frac{A}{D} \lambda \sigma_{A}(-T)\right) \Leftrightarrow \sigma_{A}=\frac{P}{B e^{-r T}}\left(-\frac{D}{\lambda A\left(1-\Phi\left(-d_{1}-\sigma_{A} \sqrt{T}\right)\right) T}\right),
$$

where $\frac{d D}{D}=\frac{d D}{d A} \frac{A}{D} \frac{d A}{A}=\mu_{D}-r=\left(1-\Phi\left(d_{1}\right)\right) \frac{A}{D} \lambda \sigma_{A}=-\frac{1}{T} \ln \left(1-\frac{P}{B e^{-r T}}\right)$, with market value of debt $D$, and constant leverage $\Phi\left(d_{1}\right)$. The new post-shock funding spread is then calculated as above. 


\section{APPENDIX IV: SOVEREIGN RISK MODEL}

The calculation of haircuts on fixed income holdings under different macro scenarios is based on an IMF-developed model for the valuation of sovereign debt using information from CDS markets. Sovereign bond prices for each year under each scenario are calculated using market expectations of default risk as reflected in forward rates on five-year sovereign CDS contracts. Five-year bonds are assumed to be representative of the maturities of banks' bond holdings. Bonds for which market quotes from Bloomberg were available, with maturities between 4.5 and 6.5 were also included as in CEBS.

The standard pricing formula for coupon-bearing bonds is reconciled with the zero-coupon bond pricing formula

$$
P_{B}=\exp \left(-r_{T} T\right)(1-L G D \times P D(T)),
$$

with the cumulative probability of default (PD) and loss given default (LGD), in order to project bond prices contingent on changes in idiosyncratic risk (irrespective of changes in the term structure of yields). Since the sample bonds carry regular coupon payments, the cash flow pricing formula

$$
P_{b, T-t}=\prod_{k=1}^{T-t} \frac{c}{\left(1+r_{t}\right)^{(T-t) / n}}+\frac{f}{\left(1+r_{t}\right)^{T-t}}
$$

of the bond $b$ in year $t$ and time to maturity $T-t$ is stripped of coupon payments $c$ (with payout frequency $n$ ) and set equal to the quasi-zero coupon price at the last observable sample date after controlling for changes in market valuation over the course of 2010 in excess of baseline expectations of each country-specific yield-to-maturity according to CEBS. Thus, one can write

$$
P_{b, T-t}=\frac{f}{\left(1+r_{t}\right)^{T-t}}=\exp \left(\left(-r_{f} t+\left(Y T M_{\text {end }-2010, \text { baseline }}-Y T M_{\text {end }-2010, a c t u a l}\right)+\frac{s_{C D S}}{10,000}\right)(T-t)\right),
$$

where $r_{t}$ is the yield in each year, $f$ is the face value and the idiosyncratic risk is represented by the five-year cash CDS spread $s_{C D S, j}=-\ln (1-L G D \times P D(t)) / T$ of country $j$. Note that the actual end-2010 YTM refers to the observed YTM on December 31, 2010. The equation above is then solved for the risk-free rate $r_{f}$ at end-2010 (before the first forecast year) by maximum likelihood. 
For all bonds of each sample country, the future prices $P_{b, t, j}$ up to five years are calculated by applying the probability distribution of the forward five-year sovereign CDS spread $F\left(s_{C D S, j}\right)_{t}$ to the zero-coupon pricing formula $P_{b, t, j}=\exp \left(\left(-r_{t} T+F\left(s_{C D S, j}\right)_{t} / 10,000\right) t\right)$ in order to inform estimates of default risk (and haircuts relative to end-2010) for each year of the forecast horizon. This is done for several bonds of each sample country (with a residual maturity $T$ of about five years).

More specifically, the dynamics of monthly variations of expected default risk reflected in the forward rates on CDS spreads $F\left(s_{C D S, j}\right)_{t}$ between January 2009 and December 2010 are parametrically calibrated as a generalized extreme value distribution with point estimates $\hat{x}_{t, a}=\hat{\mu}_{j}+\hat{\sigma}_{j} / \hat{\xi}_{j}\left((-\ln (a))^{-\hat{\xi}_{j}}-1\right)$, where $1+\xi_{j}\left(x-\mu_{j}\right) / \sigma_{j}>0$, scale parameter $\sigma_{j}>0$, location parameter $\mu_{j}$, and shape parameter $\xi_{j}=0.5 .{ }^{36}$ The higher the absolute value of shape parameter, the larger the weight of the tail and the slower the speed at which the tail approaches its limit. ${ }^{37}$ For the baseline, the median $\left(50^{\text {th }}\right.$ percentile) for $\hat{x}_{t, a=0.5}$ is chosen. Since haircuts under the adverse scenario should reflect the volatility of market expectations, country-specific shocks to $F\left(s_{C D S, j}\right)$, are assumed at the $75^{\text {th }}$ percentile (for the mild "double dip" scenario and the slow growth scenario (“adverse 1"), and $90^{\text {th }}$ percentile (for the severe "double dip" scenario ("adverse 2") of the probability distribution. Thus, for each year over

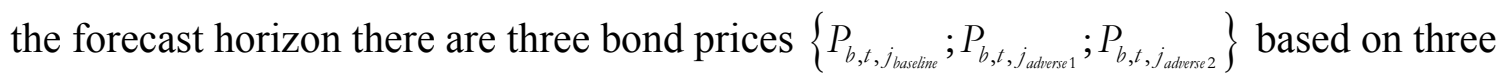

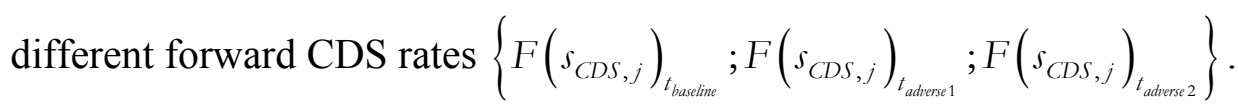

Corresponding haircuts were calculated for each bond from changes in bond prices relative to the base year 2010, using the following specification

$$
\Delta P_{b, t, j}=\left(P_{b, t, j} / P_{b, 0, j}-1\right) \times 100,
$$

\footnotetext{
${ }^{36}$ The upper tails of most (conventional) limit distributions (weakly) converge to this parametric specification of asymptotic behavior, irrespective of the original distribution of observed maxima (unlike parametric VaR models).

${ }^{37}$ All raw moments are estimated by means of the Linear Combinations of Ratios of Spacings (LRS) estimator.
} 
where $P_{b, 0}$ is the bond price in the base year..$^{38}$

The haircut $h$ for each sovereign $j$ is calculated as an issuance size-weighted average of individual projected haircuts applied to a $k$-number of bonds outstanding, ${ }^{39}$ so that

$$
h_{t, j}=\max \left(\sum_{b=1}^{k} \Delta P_{b, t, j} \times A m t_{b, j}\left(\sum_{b=1}^{k} A m t_{b, j}\right)^{-1}, 0\right),
$$

where $\Delta P_{b, t, j}$ is the haircut on bond $b$, and $A m t_{b}$ is the outstanding amount of bond $b$ issued by country $j$. These haircuts should then be applied to banks' sovereign bond exposures to countries $^{40} j \in J$ held in both the banking and trading books as of end-2010. The sovereign bond losses or changes in valuation in each year $t$ over the forecast horizon are calculated as $\sum_{j}^{J} h_{t, j} \times$ exposure $_{0, j}$, based on a bank's total exposure to country $j$ at end-2010. Sovereign exposure gains, should they materialize, are ignored for stress test purposes.

\footnotetext{
${ }^{38}$ Note that the haircut estimation is not fully accurate, because in each year over the projected time horizon, the projected yield to maturity is imposed on an unchanged set of bonds. This implies no new government issuance (and time-invariant coupon), which overstates the actual haircut (unlike in cases when the sample of bonds changes and the remaining maturity is kept constant over the projected time period).
}

${ }^{39}$ Haircuts cannot take negative values when price appreciation occurs between years (e.g., in response to "safe haven flows").

${ }^{40}$ Austria, Belgium, France, Germany, Greece, Ireland, Italy, Luxembourg, The Netherlands, Portugal, Spain, Sweden, Switzerland, UK, and the United States. 


\section{APPENDiX V. SOlvenCy STREsS TeStS: Desired OUTPuT}

\section{Appendix Table 4. Suggested Output Template for Reporting by Firms to FSA}

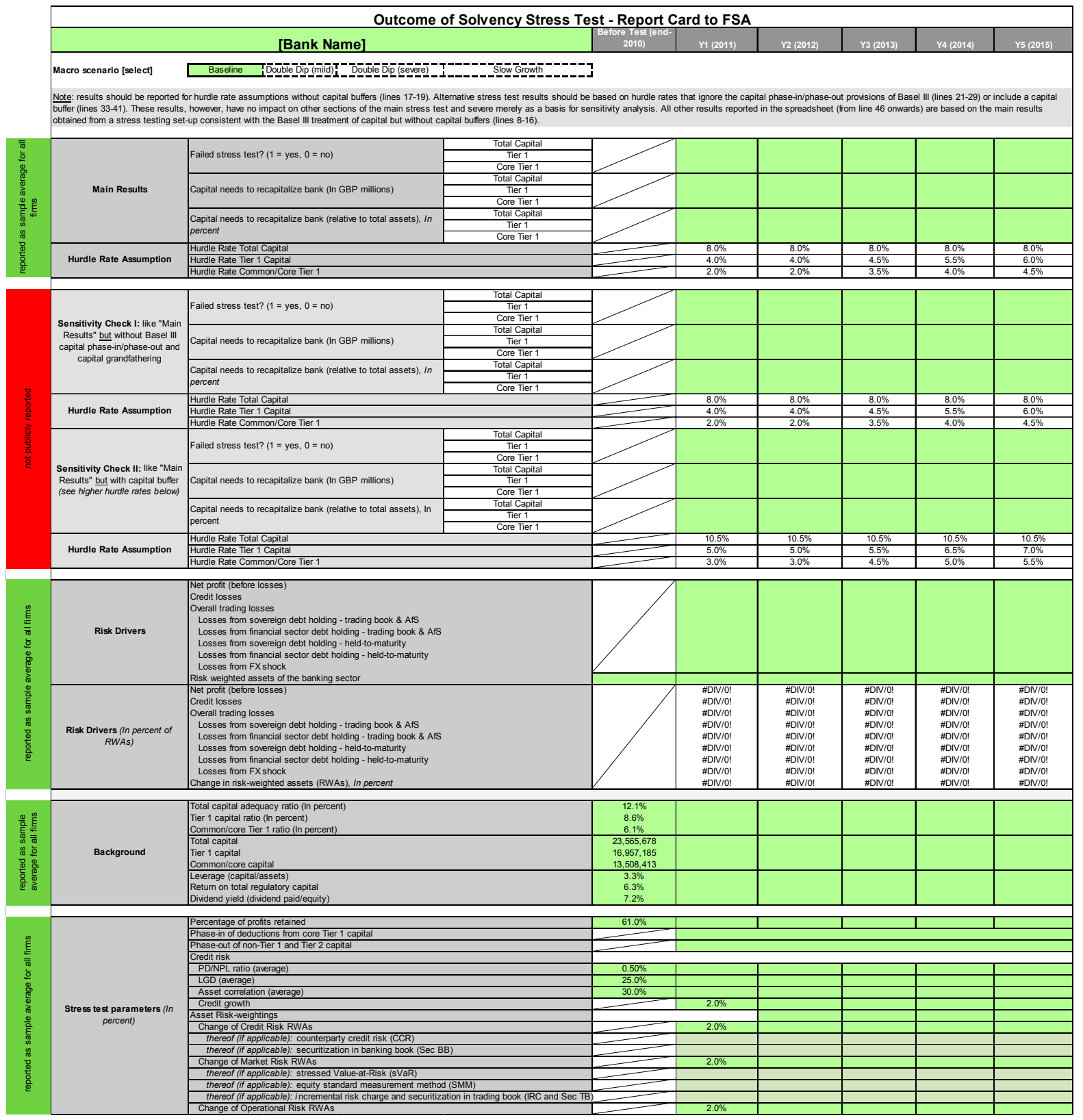

CInternational Monetary Fund. Not for Redistribution 
Appendix Table 5. Suggested Output Template for Reporting by FSA to IMF

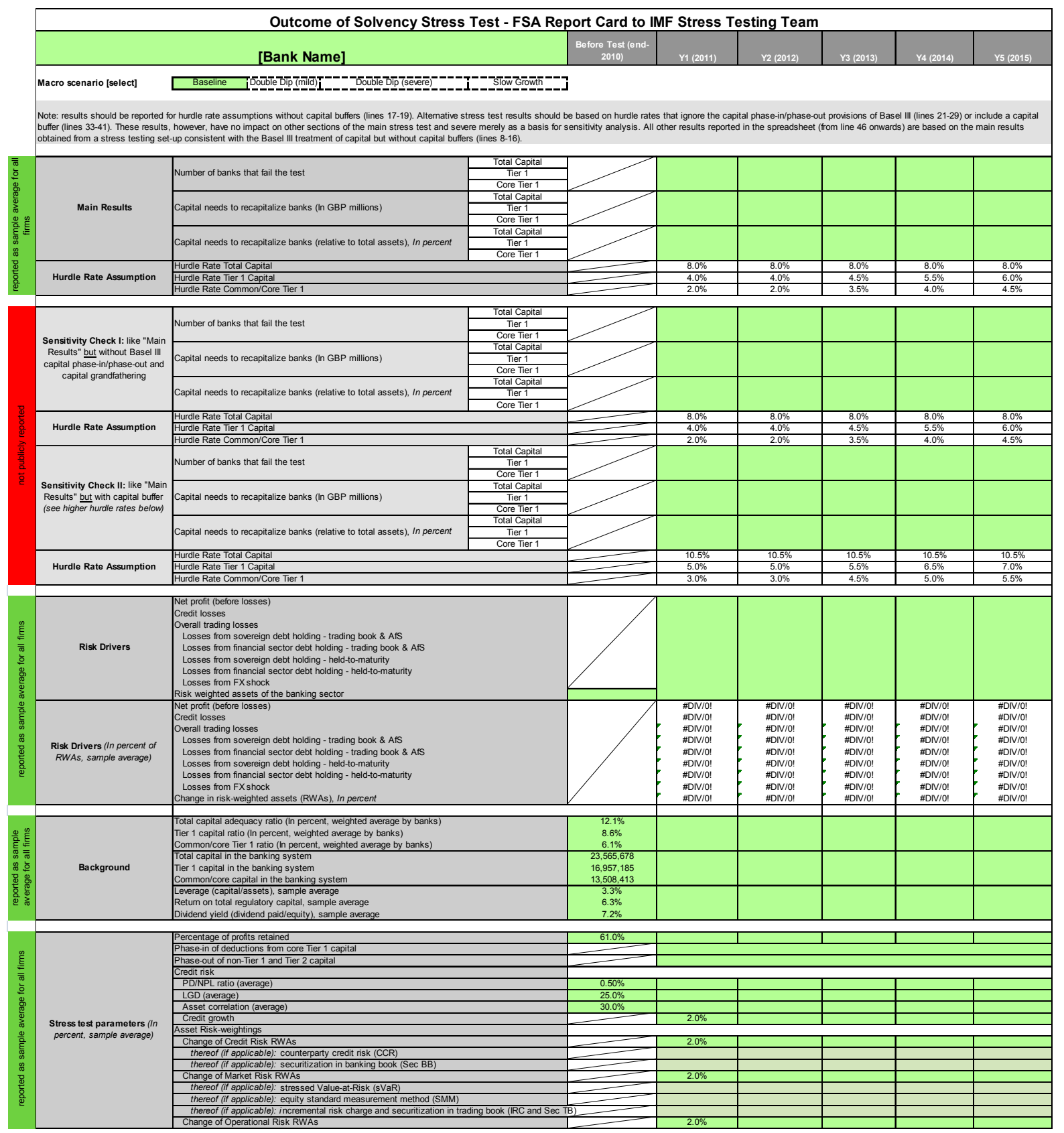


Appendix Table 5. Suggested Output Template for Reporting by FSA to IMF (continued)

\begin{tabular}{|c|c|c|c|c|c|c|c|c|}
\hline \multicolumn{3}{|c|}{ Distribution of Core Tier 1 Capital } & \multirow{2}{*}{$\begin{array}{c}\text { Before Test (end- } \\
2010 \text { ) } \\
4.1 \% \\
5.3 \% \\
6.0 \% \\
8.6 \% \\
12.4 \% \\
\end{array}$} & \multirow[t]{2}{*}{ Y1 (2011) } & \multirow[t]{2}{*}{ Y2 (2012) } & \multirow[t]{2}{*}{ Y3 (2013) } & \multirow[t]{2}{*}{ Y4 (2014) } & \multirow[t]{2}{*}{ Y5 (2015) } \\
\hline By ratio & \begin{tabular}{|l} 
Percentile \\
Percentile \\
Percentile \\
Percentile \\
Percentile \\
\end{tabular} & $\begin{array}{l}10 \\
25 \\
50 \\
75 \\
90\end{array}$ & & & & & & \\
\hline Count & \begin{tabular}{|l|}
$>-3 \mathrm{ppts}$ \\
$-2 \mathrm{ppts}$ \\
$-1 \mathrm{ppt}$ \\
Regulatory Minimum \\
$1 \mathrm{ppt}$ \\
$2 \mathrm{ppts}$ \\
$3 \mathrm{ppts}$ \\
\end{tabular} & & $\begin{array}{l}0 \\
0 \\
0 \\
0 \\
1 \\
5 \\
1 \\
\end{array}$ & & & & & \\
\hline & Distribution of Tie & & $\begin{array}{c}\text { Before Test (end- } \\
\text { 2010) } \\
\end{array}$ & Y1 (2011) & Y2 (2012) & Y3 (2013) & Y4 (2014) & Y5 (2015) \\
\hline By ratio & \begin{tabular}{|l|} 
Percentile \\
Percentile \\
Percentile \\
Percentile \\
Percentile \\
\end{tabular} & $\begin{array}{l}10 \\
25 \\
50 \\
75 \\
90 \\
\end{array}$ & $\begin{array}{l}4.1 \% \\
5.3 \% \\
6.0 \% \\
8.6 \% \\
12.4 \% \\
\end{array}$ & & & & & \\
\hline Count & \begin{tabular}{|l|}
$>-3 \mathrm{ppts}$ \\
$-2 \mathrm{ppts}$ \\
$-1 \mathrm{ppt}$ \\
Regulatory Minimum \\
$1 \mathrm{ppt}$ \\
$2 \mathrm{ppts}$ \\
$3 \mathrm{ppts}$ \\
\end{tabular} & & $\begin{array}{l}0 \\
0 \\
0 \\
0 \\
1 \\
5 \\
1\end{array}$ & & & & & \\
\hline & Distribution of To & & $\begin{array}{c}\text { Before Test (end- } \\
\text { 2010) }\end{array}$ & Y1 (2011) & Y2 (2012) & Y3 (2013) & Y4 (2014) & Y5 (2015) \\
\hline By ratio & \begin{tabular}{|l} 
Percentile \\
Percentile \\
Percentile \\
Percentile \\
Percentile \\
\end{tabular} & $\begin{array}{l}10 \\
25 \\
50 \\
75 \\
90 \\
\end{array}$ & $\begin{array}{c}4.1 \% \\
5.3 \% \\
6.0 \% \\
8.6 \% \\
12.4 \% \\
\end{array}$ & & & & & \\
\hline Count & \begin{tabular}{|l|}
$>-3$ ppts \\
-2 ppts \\
-1 ppt \\
Regulatory Minimum \\
1 ppt \\
2 ppts \\
3 ppts \\
\end{tabular} & & $\begin{array}{l}0 \\
0 \\
0 \\
0 \\
1 \\
5 \\
1\end{array}$ & & & & & \\
\hline
\end{tabular}


APPENDiX VI. Proposed Timeline for CoMpletion of SOlvenCy STREsS Test

March 15, 2011

March 23-April 5, 2011

May 4, 2011

May 13, 2011
Firms receive stress testing guidelines from FSA

Technical follow-up during second IMF FSAP mission

Firms report finals results and FSA prepares output for IMF FSAP team

FSA communicates results to IMF FSAP team 